\title{
Designing for success : investigating design as a driver for innovation
}

Citation for published version (APA):

Dülfer, N. (2014). Designing for success : investigating design as a driver for innovation. [Doctoral Thesis, Maastricht University]. Maastricht University. https://doi.org/10.26481/dis.20141204nd

Document status and date:

Published: 01/01/2014

DOI:

10.26481/dis.20141204nd

Document Version:

Publisher's PDF, also known as Version of record

\section{Please check the document version of this publication:}

- A submitted manuscript is the version of the article upon submission and before peer-review. There can be important differences between the submitted version and the official published version of record.

People interested in the research are advised to contact the author for the final version of the publication, or visit the DOI to the publisher's website.

- The final author version and the galley proof are versions of the publication after peer review.

- The final published version features the final layout of the paper including the volume, issue and page numbers.

Link to publication

\footnotetext{
General rights rights.

- You may freely distribute the URL identifying the publication in the public portal. please follow below link for the End User Agreement:

www.umlib.nl/taverne-license

Take down policy

If you believe that this document breaches copyright please contact us at:

repository@maastrichtuniversity.nl

providing details and we will investigate your claim.
}

Copyright and moral rights for the publications made accessible in the public portal are retained by the authors and/or other copyright owners and it is a condition of accessing publications that users recognise and abide by the legal requirements associated with these

- Users may download and print one copy of any publication from the public portal for the purpose of private study or research.

- You may not further distribute the material or use it for any profit-making activity or commercial gain

If the publication is distributed under the terms of Article $25 \mathrm{fa}$ of the Dutch Copyright Act, indicated by the "Taverne" license above, 


\section{Designing for Success}

Investigating Design as a Driver for Innovation 


\section{(C) Nils Dülfer, Maastricht 2014}

All rights reserved. No part of this publication may be reprinted or utilized in any form or by any electronic, mechanical or other means, no known, or hereafter invented, including photocopying and recording, or in any information storage or retrieval system, without written permission of the copyright owner.

\section{Cover Design: Moritz Krämer}




\title{
Designing for Success
}

\section{Investigating Design as a Driver for Innovation}

\author{
DISSERTATION \\ to obtain the degree of Doctor at Maastricht University, \\ on the authority of the Rector Magnificus, Prof. Dr. L.L.G. Soete \\ in accordance with the decision of the Board of Deans, \\ to be defended in public \\ on Thursday 4 December 2014, at 16.00 hours \\ by
}

Nils Dülfer 


\section{Supervisor:}

Prof. Dr. Martin Wetzels

\section{Co-supervisor:}

Dr. Dominik Mahr

\section{Assessment Committee:}

Prof. Dr. Gaby Odekerken-Schröder (voorzitter)

Prof. Dr. Jos Lemmink

Prof. Dr. Annouk Lievens, Universiteit Antwerpen 


\section{ACKNOWLEDGEMENTS}

This dissertation is not only the result of my work in front of the keyboard. In fact, many people have had an influence on that piece of work. Some of them, I have met recently, others I have known for a long time. Those who had the most direct impact shall be mentioned here.

First of all, I would like to thank my supervisor and promoter Prof. Dr. Martin Wetzels for giving me the opportunity to go on that unique journey and supporting me whenever it was needed. You believed in the topic right from the start and were a great mentor for realizing my ideas. I'm especially indebted to you for your methodological advice, for your interdisciplinary insights and for the inspiring conversations we had.

Second, but not less, I would like to express my gratitude to Dr. Dominik Mahr. I greatly benefited from your in-depth knowledge on marketing and innovation management. Thank you for your persistence and patience when reviewing the manuscripts. Thank you also for introducing me to all important matters of university life beyond the scientific work.

Apart from Maastricht University, I am grateful to Ute Keidel, IRC Manager at A.T. Kearney, who enabled me to combine scientific research with research in practice and Dr. Eva Diedrichs, Managing Director of IMP3rove - European Innovation Management Academy, who shared with me her practical insights on innovation management and gave me access to that incredible database. These collaborations enriched this dissertation substantially.

Special thanks go to my better half Andrea, who not only shared with me the moments of brightness, but also kept me smiling when clouds covered the sky. Thank you for your uninterrupted mental and emotional support and your constructive feedback on many parts of the dissertation. Thank you also for your understanding of the "night shifts" and weekends spend on the dissertation.

Finally and most of all, I would like to thank my parents Helmut and Renate, for not only supporting me while working for this project, but rather supporting me in all that I was interested in, since I was a child. Showing me the variety of things on earth was the foundation for the interdisciplinary perspective reflected in this dissertation. Making me feel that you believe I am doing the right thing always kept me writing and will support me further in the future. Ich danke Euch beiden sehr!

Nils Dülfer

Düsseldorf, October 2014 


\section{DEDICATION}

This dissertation is dedicated to my parents, Helmut and Renate Dülfer, for whom education has always been a supreme value. 


\section{TABLE OF CONTENTS}

CHAPTER 1. INTRODUCTION ............................................................................................ 1

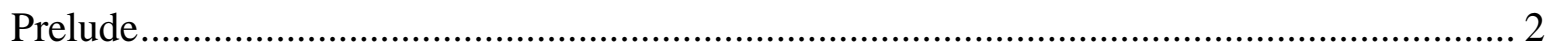

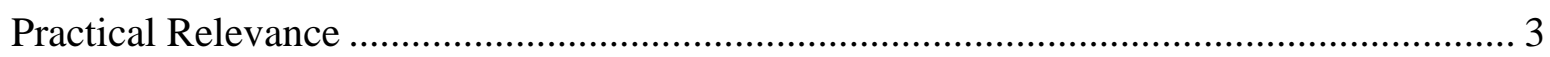

An Overview of Outcome-Based Design Research ............................................................. 5

Research Objectives and Questions ............................................................................. 7

CHAPTER 2. A SYSTEMATIC REVIEW OF RESEARCH ON DESIGN SUCCESS: SYNTHESISING DESIGN PERSPECTIVES, RESPONSES AND RETURNS ............. 11

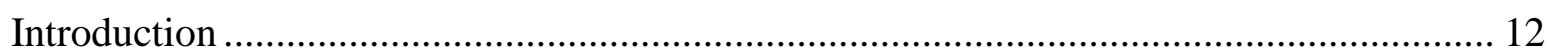

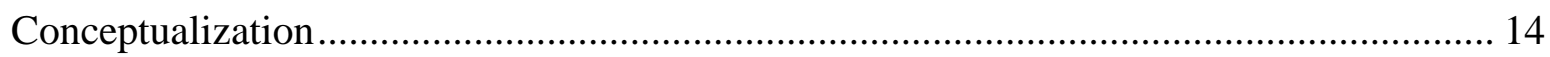

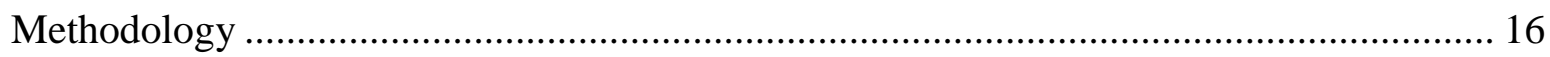

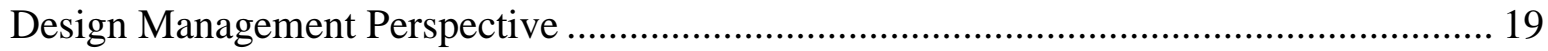

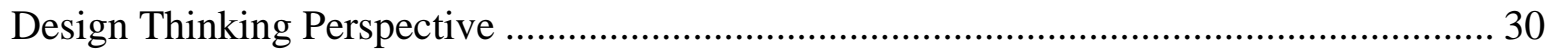

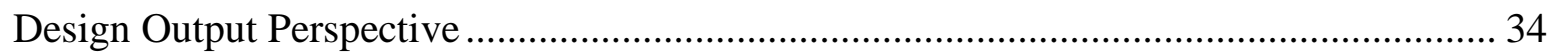

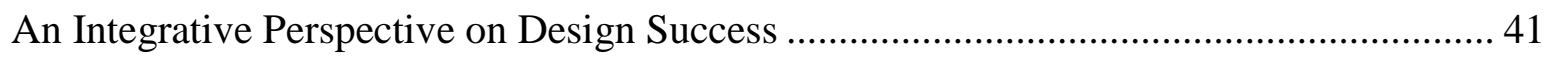

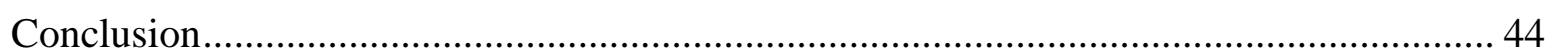

Appendix 1 - Summary of Extant Studies per Research Stream .................................... 45

Appendix 2 - Overview of Avenues for Further Investigations ....................................... 51

CHAPTER 3. DESIGN ORIENTATION OF FIRMS: CONCEPTUALIZATION AND EMPIRICAL INVESTIGATION OF ITS ANTECEDENTS AND INNOVATION

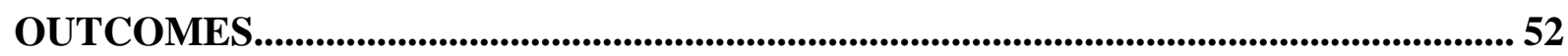

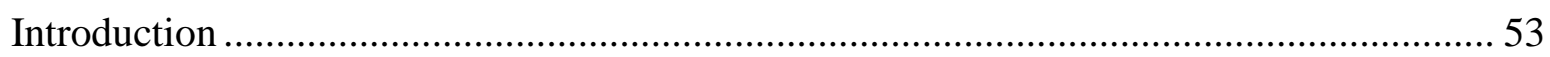

Theoretical Background and Hypotheses Development .............................................. 56

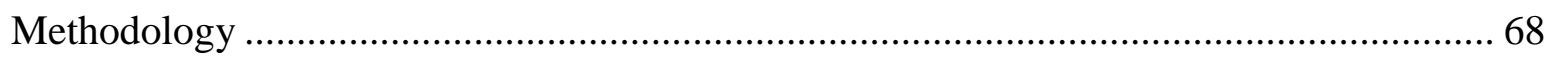

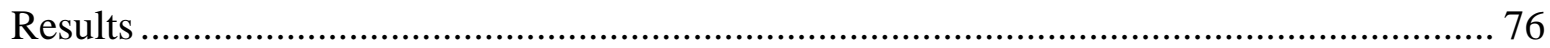

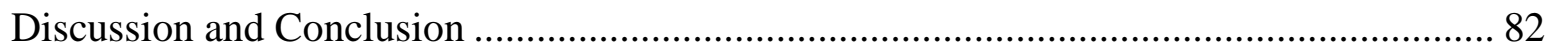

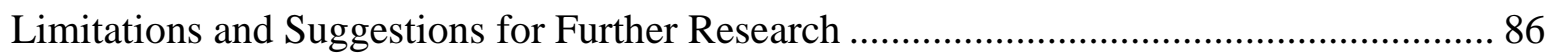

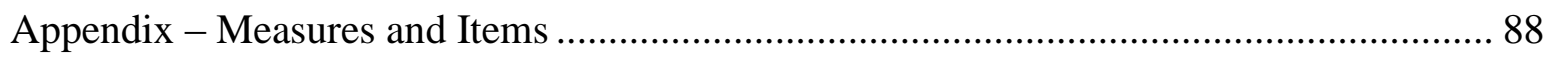

CHAPTER 4. DESIGN THINKING DURING THE FUZZY FRONT END: AN

EXPLORATION OF THE IMPACT OF DESIGN THINKING ON TEAMWORK

AND IDEA QUALITY .................................................................................................................... 91

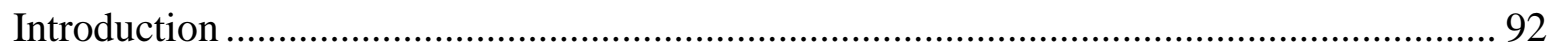


Conceptualizing Design Thinking as an Iterative Front End Process 95

Relationships between Design Thinking, Teamwork and Idea Quality ............................ 99

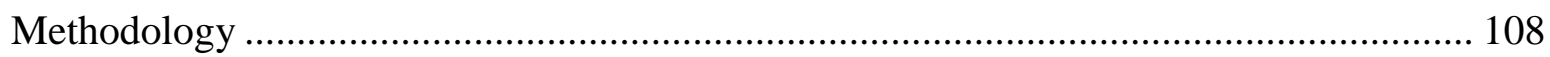

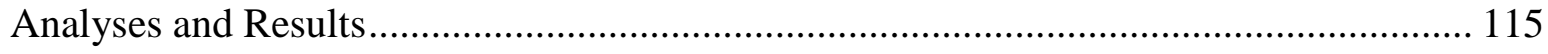

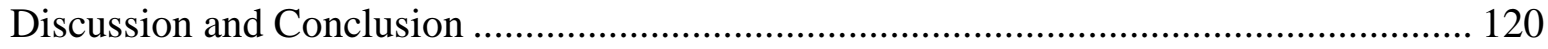

Limitations and Suggestions for Further Research .................................................... 124

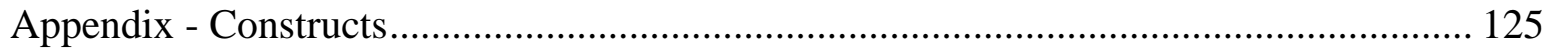

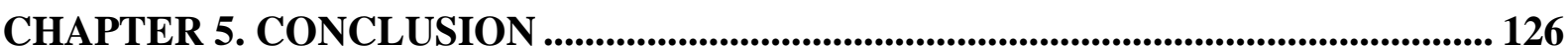

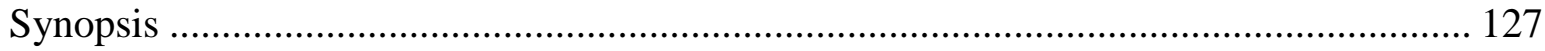

Implications for Managers, Academia and Policy Makers ........................................... 132

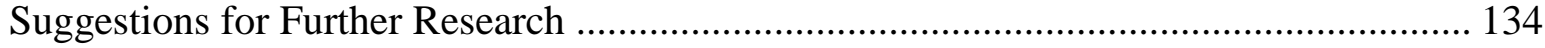

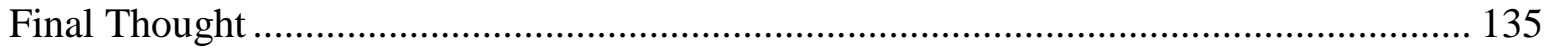

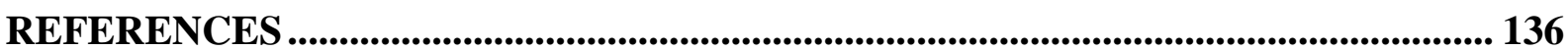

SUMMARY

VALORIZATION OPPORTUNITIES - A EUROPEAN PERSPECTIVE................... 150 
CHAPTER 1. INTRODUCTION 


\section{Prelude}

The past century has shown prominent examples of design-led product innovations. US-based company Herman Miller, for instance, successfully reinvented twentieth-century furniture by collaborating with the famous designers Charles and Ray Eames (Brown, 2009). Olivetti's engagement of Ettore Sottsass resulted in the iconic Valentine typewriter (Verganti, 2009). More recently, Apple's focus on design yielded the translucent and colorful iMac, designed by Jonathan Ive, which marked a fundamental step towards Apple's turnaround from a firm making a US $\$ 1$ billion loss to the most valuable company in the world (Rindova and Petkova, 2007; Zec, 2011). Notably, many of these companies with a focus on product design also turned out to be successful innovators in less tangible domains, such as services or business models. Apple, for instance, developed a complete new system for distributing music and movies in the form of iTunes and Herman Miller offers, next to its products, innovative consultancy services to its business customers, which has led to the highest innovation industry rank in Fortune's list of the World's Most Admired Companies for several years in succession (CNNMoney, 2014).

These success stories have pointed to a positive association between companies' foci on product design and their overall innovation performance in terms of tangible and intangible results. Therefore, the past decade has seen an increased interest among company managers in deciphering the DNA of such design-oriented companies, in order to extract their design related processes, principles and tools, and apply them to various innovation contexts (Martin, 2011). Industry giants such as the software company Intuit conducted transformational initiatives to spread design processes encompassing customer observation, brainstorming, idea prototyping \& testing phases across the company (Martin, 2011). In turn, the company successfully launched 32 new products within a year (Martin, 2011). Based on a similar approach, the consumer goods company Procter \& Gamble encouraged employees to adopt 
three design principles during innovation projects, namely to develop a holistic user understanding, visualize new possibilities and bring ideas to reality, which led to an increase in the company's revenues, profits and market share (Martin, 2009). On a project level, the pharmaceutical company Pfizer applied design tools such as following customers during their everyday life or conducting small experiments with customers, which yielded products that were soon projected to become a US \$ 500 million category for the company (Liedtka, 2011). Although the levels and executions of these initiatives differ, all efforts attempted to apply design processes, principles or tools not only by designers, but especially non-design staff in order to spur not only product, but also non-product innovations.

Following recent calls for more research on design in innovation (Di Benedetto, 2012; Marketing Science Institute, 2014) and service contexts (Ostrom et al., 2010), the present thesis seeks to investigate how these new, widespread design applications within companies contribute to innovation management. Thereby, this thesis aims to provide a more holistic perspective on design success phenomena.

\section{Practical Relevance}

Encountering the value of design processes, principles and tools for product and non-product innovations, policy makers in Asia, Europe and the USA developed design funding schemes and programs in order to spur innovation and foster growth (Beckman and Barry, 2007; European Commission, 2009a). Yet, European policy makers also identified the key barriers that still hinder the widespread use of design across industries, i.e. a lack of understanding concerning the potential of design, a lack of knowledge and tools to evaluate the return on design as well as a lack of design skills among other professions (European Commission, 2009b). 
A lack of understanding concerning the potential of design might be traced back to a lack of knowledge about both the "bullet" and the "target": first, there exists a variety of different design interpretations (see Black and Baker, 1987; Gemser and Leenders, 2001; Lindström and Pajarinen, 2006 for related discussion), that have changed over time (Beckman and Barry, 2007; Perks et al., 2005), which makes it difficult to develop a shared understanding of what is meant by design (Ravasi and Stigliani, 2012; Whicher et al., 2011). Second, design processes and design outputs influence people and organizations in numerous ways (Crilly et al., 2004; Hertenstein et al., 2005), which makes it difficult for managers to extract and grasp these numerous impacts (The National Agency for Enterprise and Housing, 2003). Therefore, the first study of this dissertation systematically reviews the extant research of quantitative design studies across the innovation, policy, design and management literature and synthesizes its interdisciplinary insights to provide a holistic overview of how design may lead to economic success (chapter 2). This perspective shall help managers to develop a more integral understanding of the impact of design on people and organizations alike.

A better understanding of design and its outcomes also builds the basis to assess the return on design, which was named as a second barrier for not using design processes, principles and tools within organizations (European Commission, 2009b). In fact, the usefulness of design for innovation needs to be gauged with quantitative evidence, if managers, investors or policy makers shall be convinced of planned design efforts (Verganti, 2009; Whicher et al., 2011). In line, Thomas Lockwood (2011, p. 5), former president of the design management institute, points out that "[t]oday in a world of Six Sigma, lean manufacturing, cost cutting, and downsizing, it is more important than ever to measure everything, even intangibles, and that includes design." Hence, chapter 3 assesses not only how companies can become more design oriented, but also sheds new empirical light on the benefits of this management approach from a firm perspective. 
Zooming into innovation projects, chapter 4 quantifies the usefulness of the design (thinking) process, when being applied by teams, which build the nucleus of innovation activities. In particular, it demonstrates how teams of non-designers benefit from adopting the design process during the fuzzy front end of innovation projects. In doing so, this latter study also addresses the third barrier that hinders the widespread use of design, namely the lack of design skills among other professions (see also Seidel and Fixson, 2013 for related discussion).

\section{An Overview of Outcome-Based Design Research}

The "outcome-based design research", which seeks to assess design's impact on people and organizations, can be divided into three distinct research streams. The traditional design research focuses on the customer-product interface (e.g. Bloch, 1995; Crilly et al., 2004). Studies belonging to this stream most often try to assess people's psychological or behavioral responses towards certain product design features or aspects (e.g. Berkowitz, 1987; Page and Herr, 2002). In contrast, the design management stream (e.g. Black and Baker, 1987; Candi and Saemundsson, 2011; Chiva and Alegre, 2009) and the emerging design thinking stream (e.g. Brown, 2008; Martin, 2009) both focus on design as part of an organization (e.g. a function or a process) rather than as a product feature and assess its impact on organizations. However, design management scholars focus more on the function of designers in traditional design contexts, whereas the emerging design thinking stream assesses how non-designers and designers working on non-product innovations benefit from applying design processes and tools. In that sense, the latter stream mainly reflects the increasing interest among practitioners in transforming organizations into more design-oriented companies and applying design processes within innovation projects. 
The emerging design thinking literature has fostered a broader perspective on the previous three decades of outcome-based design research. Yet, scholars have widely neglected to shed light on the complementary or contradictory nature of these studies (Ravasi and Stigliani, 2012). Therefore, the first study addresses this lack by comparing the drivers and outcomes of these design studies as well as the theoretical underpinnings of these relationships.

Moreover, a comparison between the design thinking and the design management literature raises the question as to whether previous design management studies had a narrow focus on designers and their visual outputs when assessing the benefits of design for companies. In fact, design management studies have shown positive relationships between design efforts (e.g. in terms of design spending) and organizational benefits (e.g. sales) (e.g. Solum et al., 1996). Yet, these studies have neglected a conceptualization of design orientation that incorporates the entire organization and takes into account the cultural and processual dimensions of design. Hence, study 2 conceptualizes design orientation as an innovation management approach which transcends an organization. In doing so, study 2 draws on a central framework from the innovation management literature in order to explain which firm factors enable a design orientation and how this in turn influences innovation performances.

Although the literature on design thinking provides new insights on the applications of the design process and the work area of designers, the studies themselves are mainly anecdotal and lack of empirical and theoretical foundations, with only few exceptions (e.g. Ungaretti et al., 2009; Wattanasupachoke, 2012). The practice-oriented investigations within that literature stream highlight the success of design-based transformation initiatives (e.g. Martin, 2011) and describe the usefulness of design processes for innovation projects (e.g. Brown, 2008). Yet, more systematic and empirically backed up investigations of these new design applications remain scarce. Hence, study 3 takes a look through the lens of the innovation team to explain 
how the design thinking process influences teamwork and the quality of innovation output respectively.

\section{Research Objectives and Questions}

The objective of this dissertation is to provide a better understanding of design orientation as an innovation management approach which transcends organizations and design thinking as a process for innovation projects. In doing so, it seeks to address the research gaps outlined earlier. In particular, three studies have been conducted that seek to generate new theoretical and managerial insights on these gaps. Table 1.1 provides (page 8) an overview of the respective studies and their objectives.

\section{Chapter 2: A Systematic Review of Research on Design Success: Synthesizing Design Perspectives, Responses and Returns}

Design success, defined as the managerially relevant impact of design on its outcomes, has been discussed from various perspectives within distinct literature streams. Yet, research has widely neglected to compare these streams and integrate them. In consequence of such knowledge gap, firms still struggle to assess the full potential of design. In order to provide a more holistic overview of the benefits of design, this study systematically reviews the outcome-based literature on design. In total, 46 studies that assess design success have been identified in order to answer the following research questions:

$\mathbf{R Q}_{1}$ : How do concepts of design success differ within and across literature streams?

$\mathbf{R Q}_{2}$ : How can the perspectives on design success originating in different research streams be integrated?

RQ3: Which "white spots" within and across research streams should be addressed by further research? 
Table 1.1 Overview of Performance-Related Studies on Design in the Context of Innovation Management

\begin{tabular}{|c|c|c|c|c|c|}
\hline Study & Objective & Data Collection & Antecedents & Main Constructs & Outcome Variables \\
\hline Study 1 & $\begin{array}{l}\text { Synthesis of the } \\
\text { managerial relevant } \\
\text { impact of design on } \\
\text { its outcomes across } \\
\text { literature streams } \\
\text { (holistic } \\
\text { perspective) }\end{array}$ & $\begin{array}{l}\text { Literature review } \\
\text { of } 46 \text { studies }\end{array}$ & - & $\begin{array}{l}\text { Design as part of } \\
\text { an organization } \\
\text { and output }\end{array}$ & $\begin{array}{l}\text { Design-led response } \\
\text { Design-led organizational performance } \\
\text { Design-led shareholder return }\end{array}$ \\
\hline Study 2 & $\begin{array}{l}\text { Conceptualization of } \\
\text { design orientation } \\
\text { and investigation of } \\
\text { its drivers and } \\
\text { innovation } \\
\text { outcomes (firm } \\
\text { perspective) }\end{array}$ & $\begin{array}{l}\text { Survey among } \\
986 \text { respondents }\end{array}$ & $\begin{array}{l}\text { Top management attitude toward innovation } \\
\text { Innovation strategy implementation } \\
\text { Organizational innovation involvement } \\
\text { Employee attitude toward innovation } \\
\text { Formalization of the innovation process }\end{array}$ & Design orientation & $\begin{array}{l}\text { Innovation effectiveness } \\
\text { Innovation efficiency } \\
\text { Financial innovation performance }\end{array}$ \\
\hline Study 3 & $\begin{array}{l}\text { Exploration of how } \\
\text { the design thinking } \\
\text { process impacts } \\
\text { teamwork and } \\
\text { innovation output } \\
\text { quality (team } \\
\text { perspective) }\end{array}$ & $\begin{array}{l}\text { Experiment with } \\
\text { six teams of five } \\
\text { participants each }\end{array}$ & - & Design thinking & $\begin{array}{l}\text { Teamwork: } \\
\text { Internal communication } \\
\text { Exploitation of external sources } \\
\text { Group cohesion } \\
\text { Shared solution understanding } \\
\text { Idea quality: } \\
\text { Novelty } \\
\text { Feasibility } \\
\text { Relevance } \\
\text { Specificity }\end{array}$ \\
\hline
\end{tabular}


By answering these research questions, study 1 provides a more integrative view on the manifold ways in which companies may benefit from using design. Moreover, this perspective opens new avenues for further investigations within and across the reviewed literature streams.

\section{Chapter 3: Design Orientation of Firms: Conceptualization and Empirical Investigation of its Antecedents and Innovation Outcomes}

Despite extended applications of design processes in practice and an increasing recognition of the cultural benefits of design among scholars and practitioners alike, outcome-based design studies lack a more comprehensive interpretation of design orientation. Therefore, the second study adopts a more integral perspective and suggests five firm factors that enable a design orientation, which in turn influences innovation process effectiveness and efficiency as well as financial innovation returns. Based on firm-level data from 986 companies, partial least squares structural equation modeling is used in order to empirically answer the following questions:

$\mathbf{R Q}_{1}$ : Which organizational factors drive a firm's design orientation?

$\mathbf{R} \mathbf{Q}_{2}$ : What are the innovation process and financial outcomes of design orientation?

RQ3: What are project-, firm- and industry-related contingency effects for the antecedents and outcomes of design orientation?

Study 2 contributes to state of the art innovation literature as it conceptualizes a firm's design orientation in the context of innovation management. Moreover, the empirical results provide guidance on how to prioritize the allocation of resources and provide a more fine-grained picture on the benefits of this management approach. 


\section{Chapter 4: Design Thinking during the Fuzzy Front End: An Exploration of the Impact of Design Thinking on Teamwork and Idea Quality}

Despite rich anecdotal evidence of the usefulness of the design thinking process for innovation projects, theoretical considerations and empirical investigations remain limited. To gain a deeper understanding of the benefits of the design thinking process among novice teams, study 3 samples data from an experiment among six innovation teams each made up of 5 non-design students. Partial least squares structural equation modeling is used in order to answer the following question:

$\mathbf{R Q}_{1}$ : What is the impact of the design thinking process on teamwork and on idea quality during innovations' fuzzy front end?

By answering this question, study 3 contributes to the nascent scientific literature on design thinking. In particular, it enriches the design thinking literature by conceptualizing and specifying design thinking as a front end process for non-designers. Moreover, study 3 provides a deeper understanding of the benefits that innovation teams encounter when applying the process in innovation projects early on.

After examining the research questions outlined above in chapters 2, 3 and 4, chapter 5 will present an integrative perspective and revisit the main findings of the three studies. Against the backdrop of these findings, theoretical and managerial implications are discussed and further research directions are presented. 


\section{CHAPTER 2. A SYSTEMATIC REVIEW OF RESEARCH ON DESIGN SUCCESS: SYNTHESISING DESIGN PERSPECTIVES, RESPONSES AND RETURNS}

A manuscript based on this chapter has been submitted for publication in the European Journal of Marketing, with the following bibliographic reference: Dülfer, N., Mahr, D., and Wetzels, M. (2014). A systematic review of research on design success: Synthesizing design perspectives, responses and returns. 


\section{Introduction}

Thomas J. Watson Jr., former IBM president, once famously said that "good design is good business." Since the 1980s, researchers from various disciplines have probed the impact of design on organizational performance (e.g., Black and Baker, 1987; Gemser and Leenders, 2001; Verganti, 2009). However, the perspectives on design vary (Perks et al., 2005), as do the definitions of its benefits for firms. Traditionally, researchers have interpreted design as the result of a process (predominantly a physical product) that can be used to improve consumer responses (Bloch, 1995) and differentiate offerings within the market (Kotler and Rath, 1984). The view of design and its research then progressed to focus on its organizational and managerial implications, such as including designers in product development projects early on to improve companies' financial performance (Solum, et al., 1996). More recently, the discourse has moved to a wider interpretation of design as an innovation process that can be applied to a broad spectrum of tasks to improve innovation outputs and company performance (Johansson-Sköldberg et al., 2013).

Although studies have demonstrated design success from all these perspectives (e.g., Brown, 2008; Hertenstein et al, 2005; Page and Herr, 2002), researchers have widely neglected to compare the streams and integrate them (Ravasi and Stigliani, 2012). However, crossfertilization can add to a holistic understanding of design success and unfold new directions for further research. Such knowledge is necessary to facilitate broader dissemination and better use of design in organizations (European Commission, 2009b). Moreover, Whicher et al. (2011, p. 46) state that "if design is fully to justify its emerging profile at a policy level (particularly in Europe), researchers must answer [at least two] fundamental questions: What are the challenges associated with evaluating design? How does design enhance a company's competitiveness?" 
Study 1 helps overcome the challenges of implementing design in businesses and conducting research across different lines of inquiry. Our systematic review of design research addresses the following research questions:

- How do concepts of design success differ within and across research streams?

- How can the perspectives on design success originating in different research streams be integrated?

- Which "white spots" within and across research streams should be addressed by further research?

In particular, the intent in undertaking this study was to combine quantitative design success studies from different research streams to propose an integrative framework that shows practitioners and researchers how and in what contexts design success can be assessed. In doing so, study 1 makes two key contributions to the literature on design success. First, it provides a holistic overview of the methodologies and constructs used to capture design success in different contexts. Such an overview can help scholars choose the right approach to assess design success and help practitioners measure the benefits of companies' design efforts (Mrazek et al., 2011; Walton, 2011).

Second, the systematic review identifies research gaps within and between disparate literature streams that have previously been discussed separately (Ravasi and Stigliani, 2012). In doing so, study 1 presents a research agenda for studies on design success and identifies new areas rich in potential. In particular, by combining the different lines of inquiry, this study suggests to enrich the explanation of design success originating from the established design management literature with new conceptual considerations that the emerging design thinking literature offers. Thus, our holistic perspective offers new interpretations of established relationships. 
Chapter 2 is structured as follows. First, we define "design" against the backdrop of diverging perspectives. Next, we present a preliminary five-stage conceptual model for design success and describe the review methodology. Then, we describe the design management, design thinking and design output perspectives separately. In doing so, we underscore similarities and differences between studies, fill the conceptual model and highlight directions for further research within each stream. Finally, we present an integrative framework whereby we identify directions for further research across literature streams.

\section{Conceptualization}

\section{Defining Design}

Although there is no generally accepted definition of design, many authors agree that it can be both a process and a result of that process (e.g. Hertenstein et al., 2005; Oakley, 1990; Ravasi and Stigliani, 2012; Talke et al., 2009; Veryzer, 1995). In line with this reasoning, Potter et al. (1991, p. 11) mention that design involves "creating concepts, plans and instructions, usually in response to a brief provided by a firm or client, that enable a two or three dimensional object that did not exist previously to be made." Talke et al. (2009) recognize that authors devoted to the process perspective tend to use the term "industrial design", whereas authors taking the results perspective more often use the term "product design". However, these terms are both limited to the tangible domain of design and neglect areas such as graphic or web design. Furthermore, design has evolved and is today applied to an even broader range of contexts, as we discuss subsequently. Some authors also refer to design "as the purpose of that [design] process, and as the ability (or capability) to reach that purpose" (Ravasi and Stigliani, 2012, p. 465). Because our objective is to provide a holistic view, we broadly distinguish design as part of an organization (including design processes and designers) and design as part of an output (e.g., design of products, services, business models). 


\section{Defining Design Success}

Design as part of an organization and as part of an output are both important drivers of organizations' success. Focusing on products, Calabretta et al. (2008, p. 379) explain that "design affects company performance through its outputs insofar as correct management of the design function produces improvements in the customer interface with the product and in the perceived product value. This leads to better overall market performance for the company." Figure 2.1 presents our preliminary conceptual model, which visualizes these design success stages.

\section{Figure 2.1 The Five Design Success Stages}

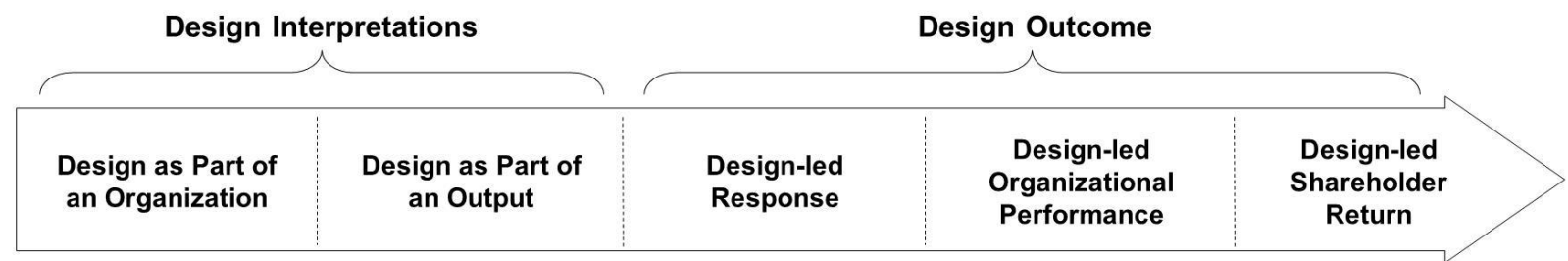

Based on this preliminary conceptual model design leads to success in the following way. Design-related activities take place within organizations and influence the design of organizational outputs (Gemser et al., 2011; Mahr et al., 2013). People respond to the design of these outputs, which in turn may influence organizational performance (Landwehr et al., 2011) and shareholder return (Hertenstein et al., 2005). The first two stages encompass the perspectives on design itself, and the latter three stages are the design outcome categories. Referring to these stages, we define design success as the managerially relevant impact of design on its outcomes.

\section{Describing the Design Success Stages}

Apple is an often-cited success story that illustrates the path described here. When Steve Jobs returned to Apple in 1997, the company faced an operating loss of more than US\$1 billion 
(Zec, 2011). Jobs, who viewed design as "the fundamental soul of a man-made creation" (Steve Jobs cited in Noble and Kumar, 2010, p. 640), increased the emphasis on design as part of the organization (Martin, 2009). In turn, the design of Apple's outputs, such as the colourful, curvy and translucent iMac, improved (Rindova and Petkova, 2007). In particular, the iMac generated positive cognitive and emotional design-led responses among consumers and other stakeholders (Rindova and Petkova, 2007). As a consequence, the organization's performance improved significantly: Apple computers' market share increased by more than $2 \%$ within one year after the launch of the iMac (Page and Herr, 2002). Apple's iPhone, another prominent example of this success story, further enhanced Apple's market valuation in 2007 (Aspara, 2009a). In 2010, Apple's stock value achieved US\$180 billion (Zec, 2011). Although not all the company's turnaround may be attributed to its design orientation, at least some of the success can conceivably be traced back to it.

\section{Methodology}

As mentioned previously, the study's aim is to provide insights into design success research fields and subfields through theoretical synthesis. Therefore, our chosen methodology follows the scheme of a systematic review as described by Tranfield et al. (2003). More specifically, we collected the relevant set of studies structurally, analysed the studies qualitatively and synthesized them according to conceptual similarities.

\section{Data Collection}

The design success stages described in Figure 2.1 served as a framework for our literature review. We took a performance-oriented perspective and focused on studies that statistically tested or at least quantified the managerially relevant influences of design as part of an organization or design as part of an output on design outcomes. We followed a snowballing technique to identify the relevant studies. At the beginning, we searched the EBSCO and 
Proquest databases for suitable scientific studies using the term "design" in combination with the following return-oriented keywords: "impact", "influence”, "response”, "preference", “satisfaction”, “purchase”, "buy”, “sales”, “revenues”, "profit”, “performance”, “stock” and "share". Next, we extended the search to the Internet using the same approach. We screened the initial set of resulting studies with respect to two particular criteria. First, we assessed whether the respective papers analysed a relationship between design and its outcomes and whether this influence was quantified; and second, we screened the studies for references to other publications that seemed to measure design success. We then sought out these cited publications and screened them the same way. Finally, we screened studies that cited the papers included in the relevant set for more recent and also forthcoming publications, including all major innovation journals. We conducted this process from October 2011 to July 2013 and found 46 studies that quantitatively assess an influence of design on its outcomes. Discussions with practitioners and academic experts validated the identified set. Finally, we reached saturation and could locate no major new studies. For a detailed summary of these studies, including the variables used and relationships assessed, see Appendix 1 to this chapter.

Fifty percent of the studies reviewed stem from three sources: the majority of studies were published in the Journal of Product Innovation Management (10), followed by European public research reports on the use of design within European companies (8) and publications by the Design Management Institute (5). The remaining articles were published in journals with a focus on marketing, consumer research, management, strategy, innovation, technology, economics, design and psychology. In addition, we included one article from the popular press and one book. 


\section{Data Analysis}

The purpose of the present meta review is to provide a comprehensive, conceptual overview of design success studies, rather than an empirical consolidation of former findings (Crossan and Apaydin, 2010). Thus, a qualitative approach was used for the data analysis. In particular, we categorised and coded the studies to identify similarities between the selected studies.

The drivers of design success considered in each reviewed study were one criterion for the matching procedure. The dependent variables the studies used were another criterion to identify clusters among the reviewed studies. Therefore, classes were built along the design outcome stages in which all dependent variables used within the reviewed studies could be sorted. First, we classified design-led responses as psychological or behavioural (Bloch, 1995; Crilly et al., 2004) and then further subdivided the psychological responses into affective and cognitive (Crilly et al., 2004) and behavioural responses into approach and avoidance (Bloch, 1995; Crilly et al., 2004). Second, we classified organizational performances as financial and non-financial results. Whereas financial results are composed of benefits and costs, nonfinancial results encompass all managerially relevant factors internal or external to the organization not measured in monetary terms (e.g., customer satisfaction, staff satisfaction). Third, we considered share price and dividend as subcategories for design-led shareholder returns. In addition to categorizing theories and variables, we mapped the recency of the publications as well as the samples and methodologies used in the reviewed studies to identify patterns within the literature.

\section{Data Synthesis}

To shed light on the similarities and differences of studies within lines of inquiry, we grouped the reviewed papers according to three research streams (Bloch, 1995; Cooper et al., 2010). Studies that take a design management (research stream 1) or design thinking perspective 
(research stream 2) predominantly focus on the influence of design as part of an organization on design outcomes. In contrast, whereas design management studies address more traditional design areas, the emerging design thinking literature analyses the effectiveness of design applications in various contexts. We identified 24 studies that belong to the design management stream and 7 that belong to the emerging design thinking stream.

Studies that take a design output perspective (research stream 3) assess the influence of design as part of an output on design-led responses and design-led organizational performances. We reviewed a total of 15 studies from this research stream.

Following the scheme of a systematic review in the management science literature, we added a "brief overview of the theoretical, practical and methodological history debates surrounding the field and sub-fields" (Tranfield et al., 2003, p. 214) as a preface to each of the following sections, which describe similarities, differences and research gaps within the research streams.

\section{Design Management Perspective}

\section{Preface: The United Kingdom's Governmental Focus on Design During the 1980s}

The root of quantified design success studies from a design management perspective can be traced backed to research in the United Kingdom, especially the Design Innovation Group (DIG).At the beginning of the 1980s, the United Kingdom faced a decline in competitiveness (Roy and Potter, 1990). A great deal of its trade deficit for manufactured goods could be attributed to products with high design relevance such as textiles, clothing, cars and consumer electronics (Roy and Potter, 1990). Therefore, the UK government conducted several initiatives such as the Funded Consultancy Scheme and the Support for Design program (Potter et al. 1991). Companies that took part in the programs received funding to engage a professional design consultant for new product development projects (Potter et al. 1991). 
The DIG, formed in 1979 at the Open University to examine the role of design as a success factor in the manufacturing industry (Potter et al., 1991; Roy, 1994), conducted a survey among 221 small and medium-sized enterprises that had received a subsidy from one of the aforementioned programs (Potter et al., 1991). The resulting “Commercial Impacts of Design” database was the first of its kind, that quantified information by which the benefits of investing in design at a project level could be assessed (Roy and Riedel, 1997).

An analysis of the data, which was collected before and after the funding, showed that $90 \%$ of the implemented projects were profitable (Potter et al., 1991). Sales increased on average by $41 \%$ for the newly designed products over the former, less design-driven products (Potter et al., 1991). Moreover, the results revealed that $25 \%$ of the projects led to new market entries and $13 \%$ to new or increased exports (Potter et al., 1991).

\section{Comparison of Studies Taking a Design Management Perspective}

Since the DIG's initial research in the 1980s, several studies have assessed effects of either the degree of organizational efforts toward design (design emphasis) or the quality of organizational design efforts (design excellence) (e.g., Candi, 2010; Roy, 1994). Although these studies use several design outcomes., most researchers chose financial benefits as the variable of choice for design success measurements (see Table 2.1). 
Table 2.1 Number of Studies per Research Stream and Design Outcome Category

\begin{tabular}{|c|c|c|c|c|c|c|c|c|c|c|}
\hline & \multicolumn{4}{|c|}{$\begin{array}{l}\text { Design-Led } \\
\text { Response }\end{array}$} & \multicolumn{4}{|c|}{$\begin{array}{l}\text { Design-Led } \\
\text { Organizational } \\
\text { Performance }\end{array}$} & \multicolumn{2}{|c|}{$\begin{array}{c}\text { Design-Led } \\
\text { Shareholder } \\
\text { Return }\end{array}$} \\
\hline & \multicolumn{2}{|c|}{$\begin{array}{c}\text { Psychological } \\
\text { Responses }\end{array}$} & \multicolumn{2}{|c|}{$\begin{array}{l}\text { Behavioural } \\
\text { Responses }\end{array}$} & \multicolumn{2}{|c|}{$\begin{array}{l}\text { Financial } \\
\text { Results }\end{array}$} & \multicolumn{2}{|c|}{$\begin{array}{l}\text { Non-financial } \\
\text { Results }\end{array}$} & \multirow[b]{2}{*}{ 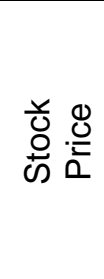 } & \multirow[b]{2}{*}{ 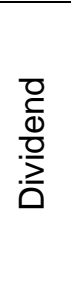 } \\
\hline & 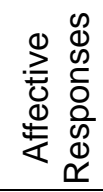 & 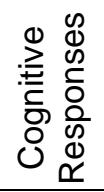 & 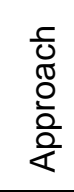 & 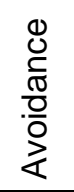 & 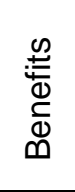 & $\begin{array}{l}\frac{n}{00} \\
0 \\
0\end{array}$ & 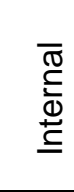 & 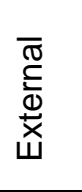 & & \\
\hline $\begin{array}{l}\text { Number of Studies in } \\
\text { Research Stream } 1\end{array}$ & 0 & 2 & 0 & 0 & 19 & 1 & 4 & 4 & 3 & 2 \\
\hline $\begin{array}{l}\text { Number of Studies in } \\
\text { Research Stream } 2\end{array}$ & 1 & 1 & 0 & 0 & 5 & 0 & 6 & 4 & 0 & 0 \\
\hline $\begin{array}{l}\text { Number of Studies in } \\
\text { Research Stream } 3\end{array}$ & 2 & 5 & 6 & 0 & 4 & 0 & 0 & 0 & 0 & 0 \\
\hline
\end{tabular}

Note: Multiple counts per study are possible

\section{Design Emphasis's Influence on Organizational Performance}

Focusing on companies' design effort, Black and Baker's (1987) early study shows that 95\% of the sampled Scottish small engineering and textile companies with no aesthetic design function had average or negative sales growth rates. In contrast, "aesthetic design personnel" was involved to a greater extent during all new product development stages in high-sales growth companies. More recent studies support the positive influence of design efforts on organizational performances, in particular, on sales. Using a sample of 84 U.S. companies from the high-tech industry, Swan et al. (2005) provide inferential support that the time and money spent on aesthetic design during product development significantly influences sales growth, market share growth and overall company performance.

Other studies find that organizational design emphasis influences non-financial results that can be assessed inside and outside the organization. For example, the National Agency for Enterprise and Housing (2003) demonstrates that increases in investment in design were associated not only with an increase in sales and an increase in export share of turnover but also with an increase in staff. Focusing on design outcomes assessed outside an organization, 
Gemser et al. (2011) discover that the involvement of designers in corporate visual identity development (including websites) is positively related to perceived firm image.

Covering both financial and non-financial results, Lindström and Pajarinen (2006) show that the frequency of design use and its overall integration in a company positively correlates with its managers' perceptions of the ability of design to increase sales, to strengthen brand or company image and to differentiate products or services from competition. Extending these findings, Gemser and Leenders (2001) find empirical evidence that the influence of industrial design intensity on organizational performance is not unconditional: although managers of companies with a higher industrial design intensity evaluated industrial designs' potential to improve product appearance significantly more favourably across industries, the authors noted a positive financial effect only for companies belonging to industries in which the use of design was less mature (Gemser and Leenders, 2001).

Researchers have uncovered comparable relationships in the service industry. Candi (2010) reveals that an emphasis on aesthetic design during new service development processes positively influences new customer sales, company image and profitability. Furthermore, a follow-up study (Candi and Saemundsson, 2011) demonstrates that the influence of aesthetic design emphasis on profitability increases when commoditization level is higher. In contrast, the results show that the influence of aesthetic design emphasis on resistance to imitation is stronger if the relative importance of aesthetic design in a firms' sector is low.

Another set of studies highlights the relevance of an organizational design emphasis for innovation effectiveness. For example, Solum et al. (1996) demonstrate that product design expenditure positively correlates with the share of sales from new or significantly modified products. Again, the relationship is moderated by the type of industry (Solum et al., 1996). More recently, the studies of the UK Design Council (2007) uncover that companies that view 
design as an integral part of their operations and businesses that use designers to add value to their offerings are more likely to have developed a new product or service during the previous three years.

The studies described here only sparingly share insights into how the firms operationalise this design emphasis (e.g., how the money for design was invested, how designers were involved within organizations). However, researchers have begun to delve into this black box, especially during the first decade of the twenty-first century. For example, the Dansk Design Center developed a design ladder framework to measure the level of design integration within a company in such an attempt (Ramlau and Melander, 2004). On the basis of this framework, studies using samples from Denmark (Ramlau and Melander, 2004), Sweden (The Association of Swedish Engineering Industries and the Swedish Industrial Design Foundation, 2005) and Ireland (Center for Design Innovation, 2007) show that an earlier integration of designers within new product development processes and a more strategic use of design were associated with a better financial performance.

Chiva et al. (2004) provide further insights into the effectiveness of organizational design foci. Using case studies of four Spanish companies from the ceramics industry, the authors discover that design management positively influences companies' performance in terms of better profitability, higher sales and lower storage or manufacturing costs (Chiva et al., 2004). In particular, a specific company culture, a strategic importance of design and the involvement of design in new product development processes are likely to improve companies' performance (Chiva et al., 2004). Five years later, Chiva and Alegre (2009) again conducted a study in the ceramics industry in Southern Europe. Using data from 182 companies, the authors find support for their hypothesis that design management mediates the relationship between investment in design and company performance. 
Focusing on the intensity of product design activities, Hise et al. (1989) shed light on how to leverage design success. Among 195 U.S.-based manufacturing companies, managers' evaluations of the commercial success of their firms' most recent new industrial offering was significantly better if more product design activities had been performed during the development process (Hise et al., 1989).

\section{Design Excellence's Influence on Organizational Performance}

As indicated previously, another class of drivers for design outcomes used in this research stream comprises variables of organizational design excellence. Roy (1994), for example, identifies a sample of companies from the plastics industry (which produces, e.g., toys, engineering products) that was particularly design conscious in terms of number of (design) awards won, number of citations by the design council and number of times competitors pointed out company for design. A comparison of those companies' financial performances with the financial performances of a randomly selected, representative sample revealed that design-conscious companies performed significantly better in terms of return on capital, profit margin, turnover growth and capital growth (Roy, 1994). The author finds comparable results for companies from the electronics, heating and office furniture industries (Roy, 1994). Furthermore, applying a similar approach, Verganti (2006) uses descriptive statistics to demonstrate that from 1994 to 2003, furniture companies from the Lombardy region in Italy known for their design excellence showed higher revenue growth than the average of the Italian and European furniture industry.

\section{Design Excellence's Influence on Investors' Responses and Shareholders'Returns}

Several studies in the design management research stream assess the influence of design excellence on the capital market. For example, the UK Design Council (2004) built a virtual design index of 63 publicly traded companies from various industries that had won design 
awards from five predefined organizations. Tracking the companies' share prices between December 1993 and December 2004, the UK Design Council finds that the design index outperformed the FTSE 100 and FTSE All Share indices by more than 200\%. This outperformance remained constant over the tracked years, which included a bear and a bull market (Design Council, 2004).

Similarly, Hertenstein et al. (2001) asked nine members of the Design Management Institute to rate the effectiveness of 51 companies in "demonstrating good design", considering factors such as design awards won and their own evaluation of the companies' design program quality. A comparison between the more-effective and less-effective design group shows that the total stock return relative to market was better for companies in the more-effective design group in four of five years tracked between 1995 and 1999 (Hertenstein et al., 2001). The authors conducted a follow-up study (Hertenstein et al. 2005) based on a larger sample from the manufacturing industry $(\mathrm{n}=92)$ and a larger expert panel from the Design Management Council and find strong support for their original results.

Finally, Aspara (2009a, b) sheds light on investors' design-led responses. In particular, his analyses reveal that Finnish institutional actors in the financial market assessed both design as part of a product and design as an organizational capability (Aspara, 2009a). In more detail, Aspara (2009b) shows that investors' positive evaluations of companies' product design significantly correlated with investors' optimism about the financial returns from a company's stock (positive correlation), investors' consideration of alternative investment targets (negative correlation) and investors' willingness to invest in the company (positive correlation). Furthermore, Aspara (2009b) finds that mentioning product design excellence in a company's investment advertisement has a positive influence on investors' willingness to invest in the company (Aspara, 2009b). 


\section{Characteristics of Design Management Literature}

In summary, studies in the first research stream provide support that across countries, industries and sample sizes, design can lead to numerous positive outcomes, as Table 2.2 indicates. The increased numbers of publications within the past decade reflect the enhanced interest in measuring design success.

Table 2.2 Comparison of Study Characteristics among Research Streams

\begin{tabular}{|c|c|c|c|c|}
\hline & & \multicolumn{3}{|c|}{ Number of Studies } \\
\hline & & $\begin{array}{c}\text { Research Stream } \\
1\end{array}$ & $\begin{array}{c}\text { Research Stream } \\
2\end{array}$ & $\begin{array}{c}\text { Research Stream } \\
3\end{array}$ \\
\hline \multirow{7}{*}{$\begin{array}{c}\text { Year of } \\
\text { Publication }\end{array}$} & 1980-1985 & & & 1 \\
\hline & $1986-1990$ & 2 & & 1 \\
\hline & $1991-1995$ & 2 & & 2 \\
\hline & $1996-2000$ & 1 & & 1 \\
\hline & 2001-2005 & 9 & & 3 \\
\hline & 2006-2010 & 8 & 4 & 5 \\
\hline & After 2010 & 2 & 3 & 2 \\
\hline \multirow{11}{*}{$\begin{array}{l}\text { Type of } \\
\text { Industry }\end{array}$} & Automotive & 1 & & 3 \\
\hline & Consumer Electronics & 4 & & 5 \\
\hline & Food & & & 6 \\
\hline & Furniture & 3 & & \\
\hline & High-Tech & 4 & & \\
\hline & Industrial Goods & 1 & & 1 \\
\hline & Pharma \& Healthcare & 1 & 2 & 1 \\
\hline & Service & 1 & 2 & 1 \\
\hline & Software & & 1 & \\
\hline & Other & 5 & 1 & \\
\hline & Various & 13 & 1 & \\
\hline \multirow{7}{*}{$\begin{array}{c}\text { Regional } \\
\text { Sampling } \\
\text { Frame }\end{array}$} & Nordic Countries & 10 & & \\
\hline & United Kingdom & 5 & & 1 \\
\hline & $\begin{array}{l}\text { Other European } \\
\text { Countries }\end{array}$ & 5 & & 2 \\
\hline & United States & 2 & 4 & 3 \\
\hline & Asia & & 3 & \\
\hline & Multinational & 6 & & 1 \\
\hline & Not specified & & & 8 \\
\hline \multirow{6}{*}{$\begin{array}{c}\text { Sample } \\
\text { Size }\end{array}$} & $1-5$ & 2 & 6 & 1 \\
\hline & $6-50$ & 3 & & 4 \\
\hline & $51-100$ & 7 & & 1 \\
\hline & $101-500$ & 10 & 1 & 6 \\
\hline & $500-1000$ & 3 & & 2 \\
\hline & More than 1,000 & 3 & & 1 \\
\hline \multirow{2}{*}{$\begin{array}{c}\text { Type of } \\
\text { Analysis }\end{array}$} & Descriptive & 10 & 6 & 2 \\
\hline & Inferential & 15 & 1 & 13 \\
\hline
\end{tabular}


Half the studies (54\%) use a cross-industry sample. Although early studies came mainly from the United Kingdom, Nordic countries have caught up and currently represent the largest share in the sampled studies (42\%). Furthermore, $25 \%$ of the studies reviewed based their analyses on multinational samples. Research using U.S. samples is comparably sparse (8\%), and none of the studies reviewed use a solely Asian-based sample. The sample sizes most often used were in the range of 101-500 objects (42\%), though $29 \%$ of the studies used a sample of $51-100$ objects.

Since the first studies from the United Kingdom in the 1980s, more recent studies have implemented larger sample sizes, new industries and new geographic areas, though the methodologies have not varied significantly over time. Typically, studies compare organizations with a high versus low design emphasis (approach used in 67\% of the studies) or with a high versus low design excellence $(33 \%)$ in terms of their performance. Design emphasis was measured as money spent on design, number of designers incorporated, time spent designing a product, number of times a design task was performed or managers' evaluations of the level of design integration. Design excellence was most often assessed by measuring the number of design awards won or design experts' or peer groups' ratings.

The most-often used metric to measure design outcomes was sales, used in $54 \%$ of the studies, followed by profit, used in $50 \%$ of the studies. The other metrics used were relatively unique to the studies. For example, Aspara (2009b) uses "willingness to invest" as a measure for investors' cognitive responses, Chiva et al. (2004) use storage and manufacturing cost to reflect further financial results and Swan et al. (2005) use time to market as a non-financial result, which is measured inside the organization. In half the studies that measure organizational performance, researchers use managers' evaluations to quantify the design outcomes; the other half use actual market data. With regard to level of observation, $67 \%$ of 
the studies use the company level and 33\% use the project level. The analyses were based on inferential statistics in $63 \%$ of the studies and descriptive statistics in $42 \%$.

\section{Directions for Further Research}

The results of the studies in the first research stream provide evidence that an organizational focus on design at a company or project level can improve company performance. However, the analyses are often based on group-wise comparisons between companies that are more versus less design excellent (Hertenstein et al., 2001) or have a high versus low design emphasis (Lindström and Pajarinen, 2006). Although this approach has led to a couple of interesting findings, it has three important limitations. First, the studies provide only limited insights into how design was incorporated into organizational structures and processes in the successful design-driven organizations. Such insights are necessary to develop a sound understanding of how to best manage design to improve performances. Second, the comparisons mostly focus on either the corporate or the project level. However, Cooper and Kleinschmidt (2007) mention that companies that are successful at one level might not be so at the other, and design-related interactions between both organizational levels might occur. Thus, a multilevel level investigation would provide new insights into the hindrances and levers of using design effectively on a corporate as well as on a project level. Third, the studies explain only sparingly what actually drives the success. In summary, the literature lacks an empirically validated, holistic managerial framework that shows how to most effectively incorporate design into organizations to optimise design outcomes. Therefore, future research in this literature stream should shed more light on the drivers of organizational design success and how they are related to one another and to different performance metrics.

Solum et al. (1996) and, more recently, the UK Design Council (2007) provide initial empirical support that the organizations' use of design can improve innovativeness. However, 
those studies provide only limited insights into the factors that determine the effectiveness of such an effort. A design-oriented managerial framework should therefore be developed in the context of innovation management. Such an investigation would be in line with the increasing research and governmental interest in design as a driver of innovativeness (e.g. Candi, 2010; Candi and Saemundsson, 2011; European Commission, 2009a; Verganti, 2009).

Focusing on moderating influences on the relationship between organizational design integration and performance, special attention should be paid to types of industries. Solum et al. (1996) do note that the influence of design emphasis on organizational performances is moderated by industry type. In addition, studies demonstrate that the "maturity" of design use (Gemser and Leenders, 2001) and the relative importance" of design within an industry (Candi and Saemundsson, 2011) are crucial characteristics that determine the moderating influence of industries. In line with Gemser and Leenders (2001), further research should examine whether these findings are applicable to various classes of industries.

Finally, further research should consider other design outcome metrics. For example, a worthwhile avenue would be to assess whether companies' design effort can be associated with an increased sales staff motivation. Automakers' sales representatives might conceivably be more motivated to present an aesthetically pleasing than a visually unattractive newly launched vehicle at a motor show. Moreover, focusing on non-financial performance outcomes, future research might examine whether there is a relationship between an organizational design engagement and customer satisfaction indices. Such an effect could occur when the integration of design functions in organizations influences the usability of the company's products, which in turn increases consumers' delight while using the products. For a summary of these future research directions, see Appendix 2 to this chapter. 


\section{Design Thinking Perspective}

\section{Preface: Design Thinking History and Examples of IDEO}

The term "design thinking", at least in the current context, can be traced back to David Kelley (Kelley, 2001), Stanford professor and cofounder of the Palo Alto-based design consultancy IDEO. Since its founding, IDEO has won more than 340 design awards (Tischler, 2009). Initially, the focus of IDEO lay in traditional design tasks such as the design of the personal digital assistant Palm V, Oral-B toothbrushes and chairs for Steelcase (Brown and Wyatt, 2010). However, since the beginning of the first decade of the twenty-first century, the company has increasingly been involved in developing solutions to problems apart from traditional, product-centred design (Brown and Wyatt, 2010).

For VisionSpring, for example, a company that delivers eyeglasses to people in developing countries, IDEO “designed” an eye-screening process for children (Brown and Wyatt, 2010). At first, the designers flew to India and tried to screen the vision of a girl in the traditional way as done in the typical course of these tests. The girl started to cry because she perceived risk in "failing" the test. To reduce the pressure in this stressful situation, the designers created a prototype of a new process and let the children's teacher perform the task. However, the child burst into tears again. As a third approach, the designers asked the girl to screen her teacher. The girl liked the task, and the other children watched enviously. Thus, by observing the children while prototyping the process, the designers recognized the potential for letting the children screen one another, which also worked for VisionSpring's practitioners and the children's teachers. Finally, VisionSpring set up 10 eye camps for children in India, screened 3,000 children and provided glasses for all 69 children who needed them. (Brown and Wyatt, 2010). 
Projects such as that for VisionSpring took IDEO from designing consumer products to designing consumer experiences' (Brown and Wyatt, 2010, p. 33). To distinguish this new kind of design work from traditional design tasks, IDEO established the term "design thinking" (Brown and Wyatt, 2010), a mixture of analytical phases in which information is gathered and synthetic phases in which solutions are developed, tested and improved (Plattner et al., 2009). Observation, brainstorming and prototyping are core elements of the design thinking process in which interdisciplinary teams are appreciated (Brown and Wyatt, 2010). Recently, the concept of design thinking has been adopted by companies such as General Electric, Intel, Toyota and Procter \& Gamble, which have begun to use design together with traditional business approaches to develop not only products and services but also new customer experiences and business models (Nagji and Locsin, 2009).

\section{Comparison of Studies Taking a Design Thinking Perspective}

Along with the increasing application of design within industries, design thinking has found increasingly more entry into academic and management literature. Although the steps of the design thinking process described in the literature differ depending on the authors (cf. Brown, 2008; Hempel, 2007; Liedtka, 2011; Martin, 2011), the concepts share core elements such as getting close to people, brainstorming in interdisciplinary groups and building prototypes. The articles that quantify the success of design thinking provide valuable insights into the concept and demonstrate which design outcomes previous research has assessed, as Table 2.2 shows.

\section{Design Approaches’ Influence on Design Outcomes}

Two subsets of articles can be assessed. The first set describes design thinking approaches on a project basis. For example, chief executive officer and president of IDEO Tim Brown (2008) explains how his firm used design thinking to improve nurses' shift-change processes in a U.S.-based hospital. The new process not only increased nurses' job satisfaction and 
improved patients' experience but also improved nurses' productivity. Brown (2008) furthermore highlights the success of design thinking for redesigning a debit card payment system in a U.S. bank. The new system attracted 2.5 million new customers within the first year after program launch, which led to 700,000 new checking accounts and 1 million new saving accounts (Brown, 2008).

Demonstrating the design thinking approach in the context of new business model design, Hempel (2007) shows how a new concept of "information kiosks", which provide Indian people with Internet access and technical support, became a success, with 1,000 businesses running six years after launch. Further highlighting the benefits of the approach on a project basis, Liedtka (2011) describes how the use of design thinking elements during the innovation process in a pharmaceutical company led to new portable product packages and bundles of consumer health care products. Those new offerings generated 5\%-10\% additional revenue for participating brands from the start on and were "soon projected to become a $\$ 500$ million category" (Liedtka, 2011, p. 15).

\section{Design Applications' Influence on Design Outcomes}

The other set of articles within the second research stream describes the application of design thinking within corporations, which touches on the field of business transformation. For example, Martin (2009) indicates a relationship between the implementation of the design thinking process within a large consumer goods company and an improved financial performance of that organization in terms of revenue, profit and market share. The firm implemented design concepts through workshops, designer involvement in business teams, cooperations with design agencies and an external design board (Martin, 2009). With a similar transformational approach, a leading U.S.-based software company launched 32 new products within a year (Martin, 2011). Martin (2011) further notes the success of these products: one 
application achieved a high net promoter score, and another had 180,000 subscribers within one year after the software was launched.

Wattanasupachoke (2012) makes an initial attempt to assess design thinking success on the basis of inferential statistics. The author conducted a survey among 114 companies listed on the Stock Exchange of Thailand. The results of the data analysis reveal a significant positive correlation between companies' focus on design thinking strategies and firm innovativeness and firm performance compared with competition over the previous three years. However, the analysis was solely based on subjective management evaluations and the used measurements remain unclear. (Wattanasupachoke, 2012)

\section{Characteristics of Design Thinking Literature}

Although design thinking has increasingly been recognized as a field in academic research, studies that quantify its impact are still sparse, as shown in Table 2.2. All articles reviewed were published after 2006. The analyses are all based on case studies, except Wattanasupachoke (2012), which is based on a larger data set and uses inferential statistics. Most case studies describe success stories of design thinking in U.S.-based companies; even examples from Asian-based companies partially involve U.S.-based design consultancies. In contrast to the preceding research stream and in line with the new perspective on areas of design application, the design thinking literature focuses to a greater extent on design tasks in social, service and software contexts, which involve intangible and even invisible content.

\section{Directions for Further Research}

Although the articles deliver some notable insights into the approaches and applications of design thinking, the authors predominantly use a descriptive approach and highlight only the successes and not the failures (Hauser et al., 2006). Therefore, more research is needed to empirically validate that design thinking leads to valuable design outcomes. Indeed, Ungaretti 
et al. (2009) point out that although application of design to business practice is increasing, empirical evidence that would justify it is still lacking. Thus, further research should examine whether design thinking in general is superior to other innovation processes.

Furthermore, Hauser et al. (2006, p. 703) point out that "opportunities exist for comparative search to identify which methods work best in what contexts." In particular, research could fruitfully test different design thinking processes against one another to examine best practice models. In particular, attention should be paid to the operationalization of the phases to answer practical questions such as where and how long observations should be conducted and which tools should be used to build prototypes. Further studies could examine which team compositions are most effective in which situations. As mentioned previously, design thinking encourages interdisciplinary teams (Brown and Wyatt, 2010). Therefore, researchers could test whether the fit between design task and team composition influences the effectiveness or efficiency of the process.

Finally, the examples noted here describe the success of design thinking for the design of processes, business models or systems across industries. Therefore, scholars might fruitfully compare the effectiveness of the process among different industries or design solutions.

\section{Design Output Perspective}

\section{Preface: Traditional Design Research at the Customer-Product Interface}

Design has long been used to differentiate, brand and add value to organizational outputs. Traditionally, firms have used this strategy for tangible design outputs, such as the Coca-Cola bottle and Alessi's teakettle (Orth and Malkewitz, 2008; Verganti, 2006). Yet the previous section indicates that applications of designers and design processes have evolved, so that less tangible design outputs such as business models or services play a greater role. However, 
studies with a focus on design outputs have not yet adopted the new design areas. Therefore, the following review focusses only on traditional design areas.

From a traditional perspective, design as a result of the design process "represents a number of elements chosen and blended into a whole by the design team to achieve a particular sensory effect" (Bloch 1995, p. 16). This definition can be applied to design areas such as products, graphics or interiors. Focussing especially on tangible outputs, some authors also refer to product form, product shape, exterior appearance or product appearance (Talke et al., 2009). Although these terms vary, Talke et al. (2009) conclude that they all refer to observable, exterior features. Design features consist of characteristics such as shape, colour, reflectiveness or materials (Bloch 1995). The combination of those design features determines an object's particular design aspects. Many authors use a three-dimensional segmentation when decomposing design into these aspects (Candi, 2006), which researchers also refer to as "properties" (Rindova and Petkova, 2007), "values" (Noble and Kumar, 2010) and "dimensions" (Gemser et al, 2006). Although the terms differ, the underlying concepts are comparable. The aesthetic aspect refers to what an object presents to the senses (Crilly et al., 2004, p. 549). The functional aspect encompasses usability and performance characteristics (Candi, 2006), such as passenger space in a car and road visibility (Noble and Kumar, 2010). Finally, the communicative aspect refers to design as a vehicle to transfer information, which "plays a central role in object perception, recognition, interpretation, understanding and use" (Veryzer, 1995, p. 641).

Authors measuring design impact from a results perspective focus predominantly on the customer-product interface. Various studies measure which design features or aspects people prefer (e.g., Garber, 1995; Raghubir and Greenleaf, 2006; Veryzer, 1993; Veryzer and Hutchinson, 1998) and how this preference varies among respondents (e.g., Hsu et al., 2000; Moss et al., 2006). This research stream is especially broad in that nearly everything people 
encounter evokes some response, which often makes it difficult to define boundaries when conducting research (Crilly et al., 2004). In this study, we use the performance-oriented view to build the boundary for our selection. In particular, the selected studies should reveal the relevant variables on which design as an output has an influence, in what contexts this influence has been assessed and especially to what extent.

\section{Comparison of Studies Taking a Design Output Perspective}

People's responses to design can be classified as psychological and behavioural responses (Bloch, 1995; Crilly et al., 2004). Psychological responses can be further subdivided into cognitive and affective responses. Cognitive responses refer to "the judgments that the user or consumer makes about the product based on the information perceived by the senses" (Crilly et al. 2004, p. 552), such as beliefs about the product and brand. Affective responses encompass emotions, feelings and moods (Crilly et al., 2004). Both types of psychological responses are considerably interrelated and influence people's behaviours (Bloch, 1995; Crilly

et al., 2004). In contrast, the behavioural responses reflect either an approach or avoidance response (Bloch, 1995; Crilly et al., 2004). Whereas approach responses encompass behaviours such as using or buying an object, avoid responses encompass the opposite (Bloch, 1995; Crilly et al., 2004). Furthermore, preferences and choices reflect behavioural responses (Chitturi et al., 2007; Zajonc and Marcus, 1982). In summary, approach behaviours are most often used as a dependent category within this research stream as noted in Table 2.1.

\section{Design Features' and Attributes' Influence on People's Responses}

Of the articles considered, 33\% selected measured the influence of design on purchase intentions or product preferences. In three cases, the authors conduct conjoint analyses using these two metrics as dependent variables (Bloch et al., 2003; Kauppinen-Räisänen, 2010; Yamamoto and Lambert, 1994). Using conjoint analysis, Yamamoto and Lambert (1994) find 
empirical evidence that even the aesthetics of industrial products such as oscilloscopes and dispense pumps had a "palpable" influence on product preferences of 33 engineers, purchasing professionals and marketers. Using the same method, Bloch et al. (2003) reveal, among other things, that the design of bathroom scales influenced business students' purchase intentions. Furthermore, Kauppinen-Räisänen (2010) demonstrate that the colour, shape and font type of nonprescription drug packages together influenced consumers' product preferences more than the type of medicine producer. For throat medicine, package colour alone had a greater influence on product preferences than the type of medicine producer (Kauppinen-Räisänen, 2010).

The advantages of conjoint analysis are twofold. First, it reveals not only which designs respondents prefer but also to what extent design as a whole influences consumer choices compared with the offering's other attributes (de Ruyter and Wetzels, 1996). Thus, researchers can extract this impact of design on consumers and compare its strength with other influences (e.g., product's brand, its price). Second, the method acknowledges that respondents are not conscious of the importance they attach to design (Martin, 2008), which is particularly important given that research confirms the subconscious level on which design operates in consumers' choice behaviour (Townsend and Sood, 2009).

Based on different methods, studies have also shown that the design of food and food packages can influence consumer behaviour. Berkowitz (1987) showed in an experiments that homemakers prefer an untrimmed versus a trimmed shape of frozen corncobs. Some of the respondents even mentioned that the untrimmed shape looked more aesthetic (Berkowitz, 1987). Furthermore, Quester and Smart (1998) conducted a survey among 20 wine experts and managers of retail outlets. Twelve respondents mentioned the front label, four the back label and three the bottle shape as influences on their purchase decision. In addition, Yang and Raghubir (2005) demonstrate that bottle design not only influences product selections but also 
purchase quantity. Using scanner panel data, the authors reveal that more elongated beer containers generated less purchase quantity than less elongated containers (Yang and Raghubir, 2005).

Another set of articles investigates the degree to which the physical appearance of consumer electronic products influences people's responses. Creusen et al. (2010) discover that the aesthetic of video recorders and the ease of use were most important for building preferences. Shedding more light on what drives these influences, Dawar and Parker (1994) find empirical evidence that students rate the physical appearance of consumer electronics as an important sign of quality when purchasing electronic products. In addition, Page and Herr (2002) show that the aesthetic of laptop computers has a positive influence on students' product liking, whereas brand strength exhibits no influence.

A further set of studies shows that design influences brand impressions and brand beliefs (Orth and Malkewitz, 2008; Pantin-Sohier, 2009). Orth and Malkewitz (2008) exposed members of a research panel to pictures of various wine bottles that had been pretested as being prototypical for one of five classes And asked them to indicate their brand impressions (Orth and Malkewitz, 2008). The results reveal that the holistic package designs influenced different brand personality and managerially oriented brand impressions. Using a comparable approach, Pantin-Sohier (2009) demonstrates that the colour and shape of tins of coffee and water bottles also influences brand beliefs about the price, quality and aroma of these products.

\section{Design Features' and Attributes' Influence on Organizational Performance}

Using case studies, Dawton (2011) demonstrates that a change in package design also affects subsequent design success stages, in particular, companies' financial benefits. More specifically, she describes how the change of package designs increases brand value, sales and 
number of new customers of a U.K.-based food company and the sales, profitability and market share of an Ireland-based brewery (Dawton, 2011). The author also uses the example of a Scottish tour operator's new design of marketing materials, tour brochures and shop signage, which influenced the companies' sales and return on investment (Dawton, 2011).

Using larger data sets, three authors show how the design of cars influenced car sales. Focusing on 26 car lines of a U.S. automobile manufacturer, Hoffer and Reilly (1984) find empirical support that car lines with major styling changes have significantly higher sales growth rates than car lines with minor styling changes. In a similar vein, Talke et al. (2009) show that design newness of cars compared with competing models had a positive, significant influence on sales. Focusing on particular design features, Landwehr et al. (2011) ascertain that the design of car fronts significantly influenced not only people's liking but also car sales.

\section{Characteristics of Traditional Design Literature}

In summary, the studies in the third research stream provide strong support that design as an output leads to valuable outcomes across industries, regions and sample sizes. Table 2.2 provides an overview of the studies reviewed in this research stream.

As evidenced by the span of research from the 1980s (e.g. Berkowitz, 1987; Hoffer and Reilly, 1984) to the present, this research stream demonstrates the steadily increasing importance of measuring design impact. The first decade of the twenty-first century in particular exhibits a rising interest in this topic.

The objects of inquiry most often used are in the consumer electronics (33\% of all studies) and food $(40 \%)$ industries. Although in $53 \%$ of the studies, the regions from which the samples were drawn were not mentioned, which makes it difficult to assess differences among cultures, the multinationality of the remaining studies provides some support that design is an 
important success factor across countries. Furthermore, in $40 \%$ of the studies, the sample sizes were between 101 and 500 units, underscoring the reliability of the respective results.

Table 2.2 reveals also that inferential statistics were used in $87 \%$ of all studies. From a methodological perspective, all studies focused on the visual perception of design. In $69 \%$ of the articles, respondents saw a picture of the designed object. In $13 \%$ of the studies, respondents completed a survey (e.g. on the importance of design) that contained no visual presentations. Finally, $19 \%$ of the studies use actual market data.

\section{Directions for Further Research}

Although various studies exist on the preference structure of consumers toward certain design features or aspects, research that measures the degree to which design drives design outcomes is comparatively limited. Thus, more research is needed that sheds light on that relationship. The studies described in this section focus on just one design aspect (e.g., Page and Herr, 2002), the product's total physical appearance (e.g., Creusen et al., 2010) or certain design features (e.g. Kauppinen-Räisänen, 2010). None of the studies compared whether the aesthetic, functional or communicative aspect influences a certain design outcome to a greater or lesser extent. Therefore, further research should examine which design aspects drive what design outcomes most and in what contexts.

Further research is also needed to shed light on the factors that enable, strengthen or weaken the relationships between design as an output and design outcomes. For example, the articles reviewed all focus on the visual perception of design. However, the design of objects can be perceived by other senses as well, such as the sense of touch (Crilly et al., 2004). Thus, more research is needed that explains how senses other than vision mediate the influence of design on its outcomes. Moreover, Bloch (1995) argues that culture is likely to moderate the relationship between design and consumer preferences. Thus, further research should 
investigate whether culture also influences the importance people attach to design. Likewise, researchers should take demographics into account in future studies. For example, gender, moderates the relationship between design features and the attractiveness of a product (Eckman and Wagner, 1994). Therefore, it would be worthwhile to assess whether certain demographics also influence the relevance of design, at least for certain product classes. In addition, Yamamoto and Lambert (1994) note that not only products but also product classes should be investigated. Thus, further research might investigate patterns involving the importance of design among product classes. Intangible product categories were especially underrepresented within the reviewed studies. Therefore, further research should pay more attention to that domain. For example, research could measure to what extent the design of web shops influences consumers' purchase behaviour and, in turn, companies' sales.

With respect to the design outcome categories, further research is needed that sheds light on the influence of design as an output with other dependent variables apart from people's design-led responses and financial benefits. For example, researchers could focus on nonfinancial results to research whether the more aesthetic appearance of an object leads to a better customer consultation by a company's sales staff because of higher staff motivation. Shifting the focus from the company, researchers could also measure whether a more appealing product increases word-of-mouth activities among consumers.

\section{An Integrative Perspective on Design Success}

The studies reviewed show that design can be operationalized differently and lead to numerous outcomes. However, each stream focusses predominantly on certain variables between relationships are measured, while partially neglecting variables used in other streams. Thus, this study takes a holistic perspective and discusses the white spots between research streams. 


\section{Figure 2.2 The Design Success Chain}

\begin{tabular}{|c|c|c|c|c|c|}
\hline \multirow[b]{2}{*}{ 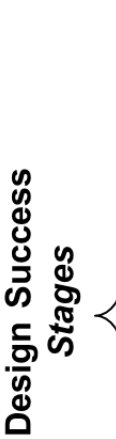 } & \multicolumn{2}{|c|}{ Design Interpretations } & & \multicolumn{2}{|l|}{ Design Outcome } \\
\hline & $\begin{array}{l}\text { Design as Part of an } \\
\text { Organization } \\
\text { (e.g. of a corporation, } \\
\text { business unit or project) }\end{array}$ & $\begin{array}{c}\text { Design as Part of an } \\
\text { Output } \\
\text { (e.g. of a product, } \\
\text { package, service, process } \\
\text { or system) }\end{array}$ & $\begin{array}{l}\text { Design-led } \\
\text { Response } \\
\text { (e.g. of customers, peer } \\
\text { groups, employees or } \\
\text { other stakeholders) }\end{array}$ & $\begin{array}{c}\text { Design-led } \\
\text { Organizational } \\
\text { Performance } \\
\text { (e.g. of a corporation, } \\
\text { business unit or project) }\end{array}$ & $\begin{array}{l}\text { Design-led } \\
\text { Shareholder } \\
\text { Return }\end{array}$ \\
\hline 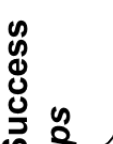 & $\begin{array}{l}\text { Design Management Per. } \\
\text { - Design Emphasis } \\
\text { - Design Excellence }\end{array}$ & $\begin{array}{l}\text { Traditional Perspective: } \\
\text { - Design Features } \\
\text { - Design Aspects }\end{array}$ & $\begin{array}{l}\text { Psychological Responses: } \\
\text { - Affective Responses } \\
\text { - Cognitive Responses }\end{array}$ & $\begin{array}{l}\text { Financial Results: } \\
\text { - Benefits } \\
\text { - Costs }\end{array}$ & \multirow{2}{*}{$\begin{array}{l}\text { Share Price } \\
\text { Dividend }\end{array}$} \\
\hline ๘ & $\begin{array}{l}\text { Design Thinking Persp } \\
\text { Design Approaches } \\
\text { Design Applications }\end{array}$ & $\begin{array}{l}\text { New Perspective } \\
\text { Design Solutions }\end{array}$ & $\begin{array}{l}\text { Behavioral Responses } \\
\text { - Approach } \\
\text { - Avoidance }\end{array}$ & Non-Financial Results & \\
\hline & \multicolumn{5}{|c|}{ Focus of Literature Stream 1} \\
\hline & \multicolumn{5}{|c|}{ Focus of Literature Stream 2} \\
\hline & \multicolumn{5}{|c|}{ Focus of Literature Stream 3} \\
\hline
\end{tabular}


The refined conceptual model shown in Figure 2.2, which we term the "Design Success Chain", extents the preliminary framework by providing an overview of the variables used to assess the influence of design on its outcomes and by highlighting the foci of the analysed research streams. The design success stages are equally applicable to the different design contexts, as our study demonstrates. However, Figure 2.2 shows that studies in the first research stream centre on the influence of organizational design emphasis and excellence on financial results; those in the second stream describe how design approaches and design applications lead to new design solutions and improve non-financial performances and finally articles in the third stream focus predominantly on the customer interface.

Looking at the streams from such a holistic perspective leads to the question of how much of the effects measured in the first research stream can be explained by the effects assessed in the second and third research streams. In particular, the product-related studies in the second stream do not reveal whether organizations' design emphases or excellence lead to superior design-led organizational performances solely due to a superior customer interface with the product. As the studies indicate, an integration of designers and design processes within organizations can also evoke a shift in the organizational culture and among the organizational tools applied which can lead to design solutions apart from products that might in turn improve organizational performance. In support of this argumentation, Ungaretti et al. (2009) show that business students adopted some of designers' methods when introduced to the concept of design thinking and when working together with design students. Furthermore, the National Agency for Enterprise and Housing (2003) survey reveals that companies working with only external rather than internal designers have lower export sales, lower increase of employment and lower increase in gross sales. This finding might indicate that companies that purchase design only externally neglect the potential that designers can offer to the organization. However, more research is necessary to assess whether designers drive 
organizational performances to a greater extent through their direct outputs in terms of the design of tangible or at least visual objects or whether the success of design-driven companies can be also traced to superior services, processes or business models developed on the basis of design thinking.

\section{Conclusion}

Study 1 shows that an increasing number of studies measure design success. In particular, the first decade of the twenty-first century has exhibited an enhanced interest in that research topic. We review three distinct research streams that differ in terms of design concepts, design applications, design success measurement approaches and design outcome metrics used. The results across all three streams reveal that designers, design processes and design outputs can lead to numerous managerial relevant outcomes. Those results, in combination with the measurement approaches, metrics and frameworks we describe, can help overcome the barriers of using design in organizations as the European Commission (2009b) notes and enhance design as a research topic across disciplines. However, more research is needed within and across the literature streams to develop a deeper understanding of the degree to which design leads to outcomes and how this influence can be managed properly. 


\section{Appendix 1 - Summary of Extant Studies per Research Stream}

\begin{tabular}{|c|c|c|c|c|c|c|c|c|c|c|c|}
\hline \multicolumn{12}{|c|}{ Research Stream 1} \\
\hline \multirow[t]{2}{*}{ Author(s) } & \multirow[t]{2}{*}{ Year } & \multicolumn{3}{|c|}{ Sample } & \multirow[t]{2}{*}{ Analysis } & \multicolumn{5}{|c|}{ Design Success Variables } & \multirow[t]{2}{*}{ Selected Findings } \\
\hline & & Description & Size & Region & & $\begin{array}{l}\text { Design as Part of } \\
\text { an Organization }\end{array}$ & $\begin{array}{l}\text { Design as } \\
\text { Part of an } \\
\text { Output }\end{array}$ & $\begin{array}{l}\text { Design- } \\
\text { led } \\
\text { Response }\end{array}$ & $\begin{array}{l}\text { Design-led } \\
\text { Organizational } \\
\text { Performance }\end{array}$ & $\begin{array}{l}\text { Design-led } \\
\text { Share-holder } \\
\text { Return }\end{array}$ & \\
\hline $\begin{array}{l}\text { Black and } \\
\text { Baker }\end{array}$ & 1987 & $\begin{array}{l}\text { Small } \\
\text { engineering } \\
\text { and textile } \\
\text { companies } \\
\end{array}$ & 61 & Scotland & $\begin{array}{l}\text { Descriptive } \\
\text { analysis }\end{array}$ & $\begin{array}{c}\text { Participation and } \\
\text { involvement of } \\
\text { design functions in } \\
\text { NPD } \\
\end{array}$ & & & Sales growth & & $\begin{array}{c}\text { Companies with higher sales growth involved designers to } \\
\text { a greater extend during NPD processes. }\end{array}$ \\
\hline Candi & 2010 & $\begin{array}{l}\text { New } \\
\text { technology } \\
\text { based firms }\end{array}$ & 98 & $\begin{array}{l}\text { Northern } \\
\text { Europea } \\
n \\
\text { country } \\
\end{array}$ & $\begin{array}{l}\text { Regression } \\
\text { analysis }\end{array}$ & $\begin{array}{l}\text { Emphasis on } \\
\text { aesthetic design in } \\
\text { new service } \\
\text { development } \\
\end{array}$ & & & New service success & & $\begin{array}{l}\text { There was a positive, significant relationship between } \\
\text { aesthetic design emphasis and all performance measures } \\
\text { except customer loyalty. }\end{array}$ \\
\hline $\begin{array}{l}\text { Candi and } \\
\text { Saemundsson }\end{array}$ & 2011 & $\begin{array}{l}\text { New } \\
\text { technology } \\
\text { based firms }\end{array}$ & 101 & $\begin{array}{l}\text { Northern } \\
\text { Europea } \\
n \\
\text { country }\end{array}$ & $\begin{array}{l}\text { Regression } \\
\text { analysis }\end{array}$ & $\begin{array}{l}\text { Emphasis on } \\
\text { aesthetic design in } \\
\text { new service } \\
\text { development }\end{array}$ & & & $\begin{array}{l}\text { Resistance to } \\
\text { imitation, and } \\
\text { profitability }\end{array}$ & & $\begin{array}{l}\text { There was a positive, significant relationship between } \\
\text { aesthetic design emphasis and resistance to imitation and } \\
\text { profitability. The influence on profitability was moderated by } \\
\text { level of commoditization. The influence on resistance to } \\
\text { imitation was moderated by industry sectors' design } \\
\text { importance. }\end{array}$ \\
\hline $\begin{array}{l}\text { Center for } \\
\text { Design } \\
\text { Innovation }\end{array}$ & 2007 & SMEs & 405 & Ireland & $\begin{array}{l}\text { Descriptive } \\
\text { analysis }\end{array}$ & $\begin{array}{l}\text { Involvement of } \\
\text { design (based on } \\
\text { the design ladder) }\end{array}$ & & & Growth in demand & & $\begin{array}{l}\text { Companies that place greater emphasis on the design } \\
\text { ladder are more likely to experience growth in demand than } \\
\text { no growth. }\end{array}$ \\
\hline $\begin{array}{l}\text { Chiva and } \\
\text { Alegre }\end{array}$ & 2009 & $\begin{array}{l}\text { Ceramic tile } \\
\text { industry }\end{array}$ & 182 & $\begin{array}{l}\text { Italy and } \\
\text { Spain }\end{array}$ & $\begin{array}{l}\text { Correlation } \\
\text { analysis }\end{array}$ & $\begin{array}{l}\text { Investment in } \\
\text { design and design } \\
\text { management }\end{array}$ & & & $\begin{array}{l}\text { Firm performance in } \\
\text { terms of growths and } \\
\text { profitability compared } \\
\text { to competitors }\end{array}$ & & $\begin{array}{l}\text { Investment in design and design management positively } \\
\text { influenced company growths and profitability. Design } \\
\text { management mediates the relationship between } \\
\text { investment in design and company performance. }\end{array}$ \\
\hline $\begin{array}{l}\text { Chiva, Alegre } \\
\text { and Lapiedra }\end{array}$ & 2004 & $\begin{array}{l}\text { Companies } \\
\text { from the } \\
\text { ceramic } \\
\text { industry } \\
\end{array}$ & 4 & Spain & $\begin{array}{l}\text { Descriptive } \\
\text { analysis } \\
\text { (case study) }\end{array}$ & $\begin{array}{c}\text { Type of product } \\
\text { design management }\end{array}$ & & & $\begin{array}{c}\text { Company } \\
\text { performance and } \\
\text { actual ROI and return } \\
\text { on sales } \\
\end{array}$ & & $\begin{array}{l}\text { Design management positively influenced company } \\
\text { performance in terms of a better profitability, higher sales } \\
\text { and lower storage or manufacturing costs. }\end{array}$ \\
\hline $\begin{array}{l}\text { Gemser and } \\
\text { Leenders }\end{array}$ & 2001 & $\begin{array}{l}\text { Manuf. of } \\
\text { furniture and } \\
\text { precision } \\
\text { instruments }\end{array}$ & 47 & $\begin{array}{l}\text { Nether- } \\
\text { lands }\end{array}$ & $\begin{array}{l}\text { Regression } \\
\text { analysis }\end{array}$ & $\begin{array}{l}\text { Industrial design } \\
\text { intensity and } \\
\text { industrial design } \\
\text { innovation strategy }\end{array}$ & $\begin{array}{l}\text { Management' } \\
\text { s evaluation } \\
\text { of industrial } \\
\text { design }\end{array}$ & & $\begin{array}{l}\text { Profit, profit growth, } \\
\text { turnover growth and } \\
\text { export sales }\end{array}$ & & $\begin{array}{c}\text { Higher industrial design intensity was associated with } \\
\text { enhanced evaluations of design's potential in improving } \\
\text { product appearance. The influence of design intensity and } \\
\text { design innovation strategy on company performance } \\
\text { differed between industries. }\end{array}$ \\
\hline $\begin{array}{l}\text { Gemser, Candi } \\
\text { and van den } \\
\text { Ende }\end{array}$ & 2011 & $\begin{array}{l}\text { Companies } \\
\text { from various } \\
\text { industries }\end{array}$ & 163 & $\begin{array}{l}\text { Nether- } \\
\text { lands }\end{array}$ & $\begin{array}{c}\text { n.a. } \\
\text { (Inferential) }\end{array}$ & $\begin{array}{l}\text { Emphasis on } \\
\text { experiential and } \\
\text { functional design; } \\
\text { involvement of } \\
\text { designers } \\
\text { in corporate visual } \\
\text { identity } \\
\text { development } \\
\end{array}$ & $\begin{array}{l}\text { Products' } \\
\text { experiential } \\
\text { and } \\
\text { functional } \\
\text { quality }\end{array}$ & & $\begin{array}{l}\text { Product's financial } \\
\text { performance } \\
\text { compared to } \\
\text { competition; perceived } \\
\text { firm image }\end{array}$ & & $\begin{array}{c}\text { Experiential (functional) design emphasis had a positive } \\
\text { influence on products' experiential (functional) quality and a } \\
\text { negative influence on products' functional (experiental) } \\
\text { quality. Involvement of designers in corporate visual } \\
\text { identity development was positively related to perceived } \\
\text { firm image. NPD projects with a high vs. medium design } \\
\text { emphasis have on average up to } 10 \% \text { better financial } \\
\text { performance. }\end{array}$ \\
\hline $\begin{array}{l}\text { Hise, O'Neal, } \\
\text { McNeal and } \\
\text { Parasuraman }\end{array}$ & 1989 & $\begin{array}{l}\text { Publicly held } \\
\text { manufacturing } \\
\text { companies }\end{array}$ & 195 & USA & $\begin{array}{l}\text { Chi-Square } \\
\text { tests }\end{array}$ & $\begin{array}{l}\text { Number and type of } \\
\text { product design } \\
\text { activities performed }\end{array}$ & & & $\begin{array}{l}\text { Commercial success } \\
\text { of the most recent new } \\
\text { industrial offering }\end{array}$ & & $\begin{array}{c}\text { The percentage of highly successful new offerings was } \\
\text { significantly larger when more compared with fewer design } \\
\text { steps were performed and when rough and detailed } \\
\text { drawings were done. }\end{array}$ \\
\hline $\begin{array}{l}\text { Lindström and } \\
\text { Pajarinen }\end{array}$ & 2006 & $\begin{array}{l}\text { Manufacturing } \\
\text { companies } \\
\text { from various } \\
\text { industries } \\
\end{array}$ & 222 & Finland & $\begin{array}{l}\text { Correlation } \\
\text { analysis }\end{array}$ & $\begin{array}{l}\text { Frequency of design } \\
\text { use and design } \\
\text { integration }\end{array}$ & & & $\begin{array}{l}\text { Design's influence on } \\
\text { company performance }\end{array}$ & & $\begin{array}{l}\text { Continuous design use and design integration positively } \\
\text { correlated with design' ability to increase sales, strengthen } \\
\text { brand or company image and differentiate products or } \\
\text { services from competition. }\end{array}$ \\
\hline
\end{tabular}


Research Stream 1 (continued)

\begin{tabular}{|c|c|c|c|c|c|c|c|c|c|c|c|}
\hline \multicolumn{12}{|c|}{ Research Stream 1 (contınued) } \\
\hline \multirow[t]{2}{*}{ Author(s) } & \multirow[t]{2}{*}{ Year } & \multicolumn{3}{|c|}{ Sample } & \multirow[t]{2}{*}{ Analysis } & \multicolumn{4}{|c|}{ Design Success Variables } & \multirow[b]{2}{*}{$\begin{array}{l}\text { Design- } \\
\text { led Share- } \\
\text { holder } \\
\text { Return }\end{array}$} & \multirow[t]{2}{*}{ Selected Findings } \\
\hline & & Description & Size & Region & & $\begin{array}{l}\text { Design as Part of } \\
\text { an Organization }\end{array}$ & $\begin{array}{l}\text { Design } \\
\text { as Part } \\
\text { of an } \\
\text { Output }\end{array}$ & $\begin{array}{l}\text { Design- } \\
\text { led } \\
\text { Response }\end{array}$ & $\begin{array}{l}\text { Design-led } \\
\text { Organizational } \\
\text { Performance }\end{array}$ & & \\
\hline $\begin{array}{l}\text { National Agency for } \\
\text { Enterprise and } \\
\text { Housing }\end{array}$ & 2003 & $\begin{array}{l}\text { Randomly } \\
\text { sampled } \\
\text { companies }\end{array}$ & 734 & Denmark & $\begin{array}{l}\text { Descriptive } \\
\text { analysis }\end{array}$ & $\begin{array}{l}\text { Companies' } \\
\text { changes in } \\
\text { investment in design } \\
\end{array}$ & & & $\begin{array}{l}\text { Increase in sales, export } \\
\text { share of turnover and } \\
\text { increase in staff }\end{array}$ & & $\begin{array}{c}\text { Increase in sales, export share of turnover and increase } \\
\text { in staff was greater for companies with increased } \\
\text { investment in design. }\end{array}$ \\
\hline $\begin{array}{l}\text { Potter, Roy, Capon, } \\
\text { Bruce, Walsh and } \\
\text { Lewis }\end{array}$ & 1991 & $\begin{array}{l}\text { SME's subsidised } \\
\text { for design } \\
\text { consultation }\end{array}$ & 221 & UK & $\begin{array}{l}\text { Descriptive } \\
\text { analysis }\end{array}$ & $\begin{array}{l}\text { External design } \\
\text { consultant } \\
\text { engagement on a } \\
\text { project basis } \\
\end{array}$ & & & $\begin{array}{l}\text { Sales, profit, payback } \\
\text { period, exports, new } \\
\text { market entries }\end{array}$ & & $\begin{array}{l}\text { The design consultant engagement lead to an increase } \\
\text { in sales, exports and number of home markets. } \\
\text { Approximately } 90 \% \text { of the implemented projects were } \\
\text { profitable. The average payback period was } 15 \text { months. }\end{array}$ \\
\hline Ramlau and Melander & 2004 & $\begin{array}{l}\text { Randomly } \\
\text { sampled } \\
\text { companies }\end{array}$ & 1500 & Denmark & $\begin{array}{c}\text { n.a. } \\
\text { (Inferential) }\end{array}$ & $\begin{array}{l}\text { Involvement of } \\
\text { design (based on } \\
\text { the design ladder) }\end{array}$ & & & $\begin{array}{l}\text { Gross revenue and export } \\
\text { share of turnover }\end{array}$ & & $\begin{array}{l}\text { Gross revenue performance was better for companies } \\
\text { that placed higher in the design ladder. Export share of } \\
\text { turnover is significantly higher for companies that placed } \\
\text { high on the design ladder. }\end{array}$ \\
\hline \multirow{2}{*}{ Roy } & \multirow{2}{*}{1994} & $\begin{array}{l}\text { Companies from } \\
\text { the plastic } \\
\text { industry }\end{array}$ & 49 & $\begin{array}{l}\text { UK and } \\
\text { Denmark }\end{array}$ & $\begin{array}{c}\text { n.a. } \\
\text { (Inferential) }\end{array}$ & $\begin{array}{l}\text { Design excellence } \\
\text { (e.g. in terms of } \\
\text { number of design } \\
\text { awards won) }\end{array}$ & & & $\begin{array}{l}\text { Return on capital, profit } \\
\text { margin, profit growth, } \\
\text { turnover growths and } \\
\text { export sales }\end{array}$ & & $\begin{array}{c}\text { Design-conscious companies performed significantly } \\
\text { better in terms of return on capital, profit margin, turnover } \\
\text { growth and capital growth than a randomly selected, } \\
\text { representative sample. }\end{array}$ \\
\hline & & $\begin{array}{l}\text { Companies from } \\
\text { the electronic, } \\
\text { heating and office } \\
\text { furniture industry }\end{array}$ & 51 & $\begin{array}{l}\text { UK (42) } \\
\text { and Other } \\
\quad(9)\end{array}$ & $\begin{array}{c}\text { n.a. } \\
\text { (Inferential) }\end{array}$ & $\begin{array}{l}\text { Design excellence } \\
\text { (e.g. in terms of } \\
\text { number of design } \\
\text { awards won) } \\
\end{array}$ & & & $\begin{array}{l}\text { Return on capital, profit } \\
\text { margin, profit growth, } \\
\text { turnover growths and } \\
\text { export sales } \\
\end{array}$ & & $\begin{array}{l}\text { Companies leading in terms of design have significantly } \\
\text { higher profit margins and return on investments than a } \\
\text { randomly selected, representative sample. }\end{array}$ \\
\hline \multirow{2}{*}{$\begin{array}{l}\text { Solum, Smith and } \\
\text { Karlsen }\end{array}$} & \multirow{2}{*}{1996} & \multirow{2}{*}{$\begin{array}{l}\text { Companies from } \\
\text { various industries }\end{array}$} & \multirow{2}{*}{954} & \multirow{2}{*}{ Norway } & $\begin{array}{l}\text { Correlation } \\
\text { analysis }\end{array}$ & $\begin{array}{c}\text { Product design } \\
\text { expenditure as } \\
\text { percentage of } \\
\text { turnover and } \\
\text { innovation costs } \\
\end{array}$ & & & $\begin{array}{l}\% \text { of sales from modified } \\
\text { and new or significantly } \\
\text { modified products }\end{array}$ & & $\begin{array}{l}\text { Share of design expenditure positively and significantly } \\
\text { correlated with share of sales from new or significantly } \\
\text { modified products, but not for all industries. }\end{array}$ \\
\hline & & & & & $\begin{array}{l}\text { Regression } \\
\text { analysis }\end{array}$ & $\begin{array}{l}\text { Product design and } \\
\text { other research and } \\
\text { development costs } \\
\text { as share of total } \\
\text { innovation spending }\end{array}$ & & & $\begin{array}{l}\% \text { of sales from modified } \\
\text { and new or significantly } \\
\text { modified products }\end{array}$ & & $\begin{array}{c}\text { Share of design expenditure had the highest influence on } \\
\text { share of sales for modified and new or significantly } \\
\text { modified products among the types of innovation } \\
\text { spending tested. }\end{array}$ \\
\hline $\begin{array}{l}\text { Swan, Kotabe and } \\
\text { Allred }\end{array}$ & 2005 & $\begin{array}{l}\text { High-tech } \\
\text { companies }\end{array}$ & 84 & USA & T-test & $\begin{array}{l}\text { Functional, } \\
\text { aesthetic, } \\
\text { technological and } \\
\text { quality capabilities }\end{array}$ & & & $\begin{array}{l}\text { Relative firm performance } \\
\text { and relative speed to } \\
\text { market }\end{array}$ & & $\begin{array}{c}\text { Sales growth, market share growth and overall; company } \\
\text { performance (compared with competition) were } \\
\text { significantly greater for companies with high vs. low } \\
\text { aesthetic capabilities. }\end{array}$ \\
\hline $\begin{array}{l}\text { The Association of } \\
\text { Swedish Engineering } \\
\text { Ind. and the SVID }\end{array}$ & 2005 & $\begin{array}{l}\text { Companies with } \\
20 \text { or more } \\
\text { employees }\end{array}$ & 1308 & Sweden & $\begin{array}{l}\text { Descriptive } \\
\text { analysis }\end{array}$ & $\begin{array}{l}\text { Involvement of } \\
\text { design (based on } \\
\text { the design ladder) }\end{array}$ & & & $\begin{array}{l}\text { Average growths in } \\
\text { turnover }\end{array}$ & & $\begin{array}{l}\text { Companies that placed higher on the design ladder had } \\
\text { a higher average growth in turnover. }\end{array}$ \\
\hline \multirow{3}{*}{ UK Design Council } & \multirow{3}{*}{2007} & \multirow{3}{*}{$\begin{array}{l}\text { Companies with } \\
\text { ten or more } \\
\text { employees }\end{array}$} & \multirow{2}{*}{1500} & \multirow{2}{*}{ UK } & \multirow{2}{*}{$\begin{array}{l}\text { Multivariate } \\
\text { analysis }\end{array}$} & $\begin{array}{l}\text { Investment and use } \\
\text { of design }\end{array}$ & & & $\begin{array}{l}\text { Contribution of design to } \\
\text { company growth }\end{array}$ & & $\begin{array}{l}\text { Turnover growth was more likely in companies that } \\
\text { increased investment in design. The chances of design } \\
\text { contributing to company growth increased by } 330 \% \text { if } \\
\text { design was used to lead and guide the NPD process. }\end{array}$ \\
\hline & & & & & & $\begin{array}{l}\text { Design integration } \\
\text { into companies } \\
\text { operations }\end{array}$ & & & $\begin{array}{l}\text { Having developed a new } \\
\text { product or service in the } \\
\text { past three years }\end{array}$ & & $\begin{array}{l}\text { Companies that viewed design as an integral part of their } \\
\text { operations were more likely to have developed a new } \\
\text { product or service during the previous three years ( } 83 \% \\
\text { did so). }\end{array}$ \\
\hline & & & 250 & UK & $\begin{array}{c}\text { n.a. } \\
\text { (inferential) }\end{array}$ & Spend on design & & & Turnover and profit & & $\begin{array}{c}\text { Every £100 spent on design increased turnover by £225 } \\
\text { and profit by £83. }\end{array}$ \\
\hline
\end{tabular}


Research Stream 1 (continued)

\begin{tabular}{|c|c|c|c|c|c|c|c|c|c|c|c|}
\hline \multirow{3}{*}{ Author(s) } & & \multirow{2}{*}{\multicolumn{3}{|c|}{ Sample }} & & \multirow{2}{*}{\multicolumn{5}{|c|}{$\frac{\text { Research Stream } 1 \text { (continued) }}{\text { Design Success Variables }}$}} & \multirow{3}{*}{ Selected Findings } \\
\hline & \multirow[t]{2}{*}{ Year } & & & & \multirow[t]{2}{*}{ Analysis } & & & & & & \\
\hline & & Description & Size & Region & & $\begin{array}{l}\text { Design as Part of an } \\
\text { Organization }\end{array}$ & $\begin{array}{l}\text { Design as Part } \\
\text { of an } \\
\text { Output }\end{array}$ & $\begin{array}{l}\text { Design-led } \\
\text { Response }\end{array}$ & $\begin{array}{l}\text { Design-led } \\
\text { Organizational } \\
\text { Performance }\end{array}$ & $\begin{array}{l}\text { Design-led } \\
\text { Shareholder } \\
\text { Return }\end{array}$ & \\
\hline \multirow{3}{*}{$\begin{array}{l}\text { UK Design } \\
\text { Council } \\
\text { (Cont.) }\end{array}$} & \multirow{3}{*}{2007} & \multirow{3}{*}{$\begin{array}{l}\text { Companies } \\
\text { with } 10 \text { or } \\
\text { more } \\
\text { employees }\end{array}$} & \multirow{3}{*}{503} & \multirow{3}{*}{ UK } & \multirow{3}{*}{$\begin{array}{l}\text { Descriptive } \\
\text { analysis }\end{array}$} & $\begin{array}{l}\text { Use of designers to } \\
\text { add value to products } \\
\text { or services }\end{array}$ & & & $\begin{array}{l}\text { Impact of design } \\
\text { on several } \\
\text { performance } \\
\text { metrics } \\
\end{array}$ & & $\begin{array}{l}\text { Businesses that used designers to add value to their } \\
\text { products or services were more likely to report an impact of } \\
\text { design on all performance measures. }\end{array}$ \\
\hline & & & & & & $\begin{array}{c}\text { Stage of NPD process } \\
\text { when design is } \\
\text { considered to add } \\
\text { value }\end{array}$ & & & $\begin{array}{l}\text { Impact of design } \\
\text { on several } \\
\text { performance } \\
\text { metrics } \\
\end{array}$ & & $\begin{array}{l}\text { Businesses that considered design to add value earlier in } \\
\text { the NPD process were more likely to report an impact of } \\
\text { design on all performance measures. }\end{array}$ \\
\hline & & & & & & $\begin{array}{l}\text { Use of designers to } \\
\text { add value to products } \\
\text { or services }\end{array}$ & & & $\begin{array}{l}\text { Having developed } \\
\text { a new product or } \\
\text { service in the past } \\
\text { three years }\end{array}$ & & $\begin{array}{l}\text { Businesses that use designers to add value to their } \\
\text { products or services were more likely to have developed a } \\
\text { new product or service in the previous three years. }\end{array}$ \\
\hline Verganti & 2006 & $\begin{array}{c}\text { Furniture } \\
\text { manufacturer }\end{array}$ & 4 & Italy & $\begin{array}{l}\text { Descriptive } \\
\text { analysis }\end{array}$ & Design excellence & & & Revenue growth & & $\begin{array}{l}\text { Companies in the Lombardy region outperformed the } \\
\text { European and Italian industry average in terms of revenue } \\
\text { growth. Companies in the Lombardy region are viewed as } \\
\text { having a greater number and strength of links within the } \\
\text { design system and a better quality of interactions among } \\
\text { key actors. }\end{array}$ \\
\hline $\begin{array}{l}\text { Hertenstein, } \\
\text { Platt and } \\
\text { Brown }\end{array}$ & 2001 & $\begin{array}{l}\text { Publicly } \\
\text { traded } \\
\text { companies }\end{array}$ & 51 & $\begin{array}{c}\text { Multi- } \\
\text { national }\end{array}$ & T-test & $\begin{array}{l}\text { Effectiveness in } \\
\text { demonstrating good } \\
\text { design } \\
\text { (rating by } 9 \text { experts) }\end{array}$ & & & $\begin{array}{l}\text { EBITda, net } \\
\text { income, cash flow } \\
\text { and net cash flow } \\
\text { ratios; growths } \\
\text { rates }\end{array}$ & $\begin{array}{l}\text { Five year } \\
\text { total stock } \\
\text { return } \\
\text { relative to } \\
\text { market }\end{array}$ & $\begin{array}{c}\text { On average, firms in the more-effective design group } \\
\text { significantly outperformed companies in the less-effective } \\
\text { design group in terms of growths rates, results relative to } \\
\text { share, EBITda relative to assets and stock market returns } \\
\text { in four of five years. }\end{array}$ \\
\hline $\begin{array}{l}\text { Hertenstein, } \\
\text { Platt and } \\
\text { Veryzer }\end{array}$ & 2005 & $\begin{array}{l}\text { Publicly } \\
\text { traded } \\
\text { companies }\end{array}$ & 93 & $\begin{array}{c}\text { Multi- } \\
\text { national }\end{array}$ & T-test & $\begin{array}{c}\text { Effectiveness in } \\
\text { demonstrating good } \\
\text { design } \\
\text { (rating by } 138 \text { experts) }\end{array}$ & & & $\begin{array}{c}\text { EBITda, net } \\
\text { income, cash flow } \\
\text { and net cash flow } \\
\text { ratios; growths } \\
\text { rates }\end{array}$ & $\begin{array}{l}\text { Five year } \\
\text { total stock } \\
\text { return } \\
\text { relative to } \\
\text { market }\end{array}$ & $\begin{array}{l}\text { On average, more design-effective firms performed better } \\
\text { on all measures except growth rate. }\end{array}$ \\
\hline $\begin{array}{l}\text { UK Design } \\
\text { Council }\end{array}$ & 2004 & $\begin{array}{l}\text { Publicly } \\
\text { traded } \\
\text { companies }\end{array}$ & 63 & $\begin{array}{c}\text { Multi- } \\
\text { national }\end{array}$ & $\begin{array}{l}\text { Descriptive } \\
\text { analysis }\end{array}$ & $\begin{array}{l}\text { Number of design } \\
\text { awards won }\end{array}$ & & & & Share price & $\begin{array}{l}\text { Companies in the design index outperformed the FTSE } \\
100 \text { and FTSE All Share indices by more than } 200 \text { percent. } \\
\text { The outperformance has been constant over the tracked } \\
\text { period (1993-2004), which included a bear and a bull } \\
\text { market. }\end{array}$ \\
\hline Aspara & 2009a & Investors & 16 & Finland & $\begin{array}{l}\text { Descriptive } \\
\text { analysis }\end{array}$ & $\begin{array}{c}\text { Organizational } \\
\text { capabilities of design }\end{array}$ & $\begin{array}{l}\begin{array}{c}\text { Design quality } \\
\text { (of mobile } \\
\text { phones) }\end{array} \\
\end{array}$ & $\begin{array}{l}\text { Investment } \\
\text { decision }\end{array}$ & & & $\begin{array}{c}\text { Institutional actors in the financial market seem to assess } \\
\text { both design as part of a product and design as an } \\
\text { organizational capability. }\end{array}$ \\
\hline \multirow[t]{2}{*}{ Aspara } & \multirow[t]{2}{*}{ 2009b } & Investors & 340 & Finland & $\begin{array}{l}\text { Correlation } \\
\text { analysis }\end{array}$ & $\begin{array}{l}\text { Overall affect for the } \\
\text { product design of the } \\
\text { company invested in }\end{array}$ & & $\begin{array}{l}\text { Willingness to } \\
\text { invest, } \\
\text { consideration of } \\
\text { alternatives, } \\
\text { optimism about } \\
\text { financial returns }\end{array}$ & & & $\begin{array}{l}\text { Positive evaluations of companies' product design } \\
\text { significantly correlated with investors' optimism about the } \\
\text { financial returns from company's stock (positive } \\
\text { correlation), investors' consideration of alternative } \\
\text { investment targets (negative correlation) and investors' } \\
\text { willingness to invest in company (positive correlation). }\end{array}$ \\
\hline & & Investors & 187 & Finland & ANOVA & $\begin{array}{l}\text { Product design } \\
\text { excellence as } \\
\text { reflected in an } \\
\text { investment ad }\end{array}$ & & $\begin{array}{c}\text { Willingness to } \\
\text { invest in } \\
\text { company's } \\
\text { stock } \\
\end{array}$ & & & $\begin{array}{l}\text { Product design emphasis in a company's investment } \\
\text { advertisement positively influenced investors' willingness to } \\
\text { invest in the company. }\end{array}$ \\
\hline
\end{tabular}


Research Stream 2

\begin{tabular}{|c|c|c|c|c|c|c|c|c|c|c|c|}
\hline \multirow{2}{*}{ Author(s) } & \multirow{2}{*}{ Year } & \multicolumn{3}{|c|}{ Sample } & \multirow{2}{*}{ Analysis } & \multicolumn{5}{|c|}{ Design Success Variables } & \multirow{2}{*}{ Selected Findings } \\
\hline & & Description & Size & Region & & $\begin{array}{l}\text { Design as Part of } \\
\text { an Organization }\end{array}$ & $\begin{array}{l}\text { Design as Part } \\
\text { of an } \\
\text { Output }\end{array}$ & $\begin{array}{l}\text { Design-led } \\
\text { Response }\end{array}$ & $\begin{array}{l}\text { Design-led } \\
\text { Organizational } \\
\text { Performance }\end{array}$ & $\begin{array}{l}\text { Design-led } \\
\text { Shareholder } \\
\text { Return }\end{array}$ & \\
\hline \multirow[b]{2}{*}{ Brown } & \multirow[b]{2}{*}{2008} & $\begin{array}{l}\text { Hospital } \\
\text { (Kaiser } \\
\text { Permanente) }\end{array}$ & 1 & USA & $\begin{array}{l}\text { Descriptive } \\
\text { (case } \\
\text { study) }\end{array}$ & $\begin{array}{l}\text { Use of the design } \\
\text { thinking process } \\
\text { within a project }\end{array}$ & $\begin{array}{l}\text { New design of } \\
\text { nurses' shift- } \\
\text { change process }\end{array}$ & $\begin{array}{l}\text { Nurses' job } \\
\text { satisfaction } \\
\text { and patient } \\
\text { experience }\end{array}$ & $\begin{array}{l}\text { Average time between } \\
\text { nurses' arrival and first } \\
\text { patient contact; nurses' } \\
\text { productivity }\end{array}$ & & $\begin{array}{l}\text { The new shift-change process was developed using the design } \\
\text { thinking process. The new process resulted in an average time } \\
\text { reduction of } 50 \% \text { between nurses' arrival and their first patient } \\
\text { contact, a significant increase in nurse's job satisfaction and } \\
\text { productivity and a significantly improved patients' experience. }\end{array}$ \\
\hline & & $\begin{array}{l}\text { Bank } \\
\text { (Bank of } \\
\text { America) }\end{array}$ & 1 & USA & $\begin{array}{l}\text { Descriptive } \\
\text { (case } \\
\text { study) }\end{array}$ & $\begin{array}{l}\text { Use of the design } \\
\text { thinking process } \\
\text { within a project }\end{array}$ & $\begin{array}{l}\text { Re-design of the } \\
\text { debit card } \\
\text { payment system }\end{array}$ & & $\begin{array}{l}\text { Number of customers, } \\
\text { number of new accounts } \\
\text { and amount of total } \\
\text { savings }\end{array}$ & & $\begin{array}{l}\text { The idea for the new card payment system was developed using } \\
\text { the design thinking process. Within the first year after program } \\
\text { launch, } 2.5 \text { million customers were attracted, } 700,000 \text { new } \\
\text { checking accounts opened and } 1 \text { million new saving accounts } \\
\text { opened. Three years after program launch savings totalled more } \\
\text { than } \$ 500 \text { million and enrolment totalled more than } 5 \text { million } \\
\text { people. }\end{array}$ \\
\hline $\begin{array}{l}\text { Brown } \\
\text { and Wyatt }\end{array}$ & 2010 & $\begin{array}{l}\text { Eyeglass } \\
\text { retailer } \\
\text { (Vision } \\
\text { Spring) }\end{array}$ & 1 & India & $\begin{array}{l}\text { Descriptive } \\
\text { (case } \\
\text { study) }\end{array}$ & $\begin{array}{l}\text { Use of the design } \\
\text { thinking process } \\
\text { within a project }\end{array}$ & $\begin{array}{l}\text { New design of } \\
\text { the eye screening } \\
\text { process }\end{array}$ & $\begin{array}{c}\text { Children } \\
\text { happiness }\end{array}$ & $\begin{array}{l}\text { Number of launched } \\
\text { projects and number of } \\
\text { screened children }\end{array}$ & & $\begin{array}{l}\text { A new eye-screening process was developed using the design } \\
\text { thinking process. The new process resulted in } 10 \text { eye camps and } \\
3,000 \text { screened children. }\end{array}$ \\
\hline Hempel & 2007 & $\begin{array}{l}\text { Service } \\
\text { provider } \\
\text { (Drishtee) }\end{array}$ & 1 & India & $\begin{array}{l}\text { Descriptive } \\
\text { (case } \\
\text { study) }\end{array}$ & $\begin{array}{l}\text { Use of the design } \\
\text { thinking process } \\
\text { during the start-up } \\
\text { phase of a } \\
\text { company } \\
\end{array}$ & $\begin{array}{l}\text { New designed } \\
\text { business model }\end{array}$ & & $\begin{array}{l}\text { Number of businesses } \\
\text { running }\end{array}$ & & $\begin{array}{l}\text { The new business model was developed using the design } \\
\text { thinking process. After six years, } 1,000 \text { businesses were running. }\end{array}$ \\
\hline Liedtka & 2011 & $\begin{array}{l}\text { Pharmaceuti } \\
\text { cal company } \\
\text { (Pfizer) }\end{array}$ & 1 & USA & $\begin{array}{l}\text { Descriptive } \\
\text { (case } \\
\text { study) }\end{array}$ & $\begin{array}{l}\text { Use of design } \\
\text { thinking elements } \\
\text { within the } \\
\text { innovation process }\end{array}$ & $\begin{array}{l}\text { New designed } \\
\text { portable product } \\
\text { bundles of } \\
\text { consumer health } \\
\text { care products }\end{array}$ & & $\begin{array}{l}\text { Revenues of new } \\
\text { product categories }\end{array}$ & & $\begin{array}{l}\text { The new products generated } 5-10 \% \text { incremental revenue for the } \\
\text { participating brands from the start on and was "soon projected to } \\
\text { become a } 500 \text { million } \$ \text { category". }\end{array}$ \\
\hline Martin & 2009 & $\begin{array}{l}\text { Consumer } \\
\text { goods } \\
\text { company } \\
\text { (Procter \& } \\
\text { Gamble) } \\
\end{array}$ & 1 & USA & $\begin{array}{l}\text { Descriptive } \\
\text { (case } \\
\text { study) }\end{array}$ & $\begin{array}{l}\text { Implementation of } \\
\text { the design thinking } \\
\text { process within the } \\
\text { organization }\end{array}$ & & & $\begin{array}{l}\text { Revenues, profit and } \\
\text { market share }\end{array}$ & & $\begin{array}{c}\text { The design thinking implementation was partially responsible for } \\
\text { an improved organizational performance in terms of revenues, } \\
\text { profit and market share. }\end{array}$ \\
\hline \multirow{3}{*}{ Martin } & \multirow{3}{*}{2011} & \multirow{3}{*}{$\begin{array}{l}\text { Software } \\
\text { company } \\
\text { (Intuit) }\end{array}$} & \multirow{3}{*}{1} & \multirow{3}{*}{ USA } & \multirow{3}{*}{$\begin{array}{c}\text { Descriptive } \\
\text { (case } \\
\text { study) }\end{array}$} & $\begin{array}{l}\text { Implementation of } \\
\text { the design thinking } \\
\text { process within the } \\
\text { organization }\end{array}$ & & & $\begin{array}{l}\text { Number of new products } \\
\text { launched }\end{array}$ & & $\begin{array}{l}\text { One year after the design thinking process was implemented, the } \\
\text { company had launched } 32 \text { new products. }\end{array}$ \\
\hline & & & & & & $\begin{array}{l}\text { Use of design } \\
\text { thinking process } \\
\text { within a project }\end{array}$ & $\begin{array}{l}\text { New designed } \\
\text { mobile phone } \\
\text { application }\end{array}$ & & $\begin{array}{l}\text { Net promoter score; } \\
\text { online store rating } \\
\text { system }\end{array}$ & & $\begin{array}{l}\text { The idea for the mobile phone application was developed using } \\
\text { the design thinking process. The product received a net promoter } \\
\text { score in the high } 80 \text { s and achieved } 4.5 \text { stars in two online stores. }\end{array}$ \\
\hline & & & & & & $\begin{array}{l}\text { Use of design } \\
\text { thinking process } \\
\text { within a project }\end{array}$ & $\begin{array}{l}\text { New designed } \\
\text { mobile phone } \\
\text { application }\end{array}$ & & $\begin{array}{l}\text { Number of new } \\
\text { customers }\end{array}$ & & $\begin{array}{l}\text { The idea for the application was developed using the design } \\
\text { thinking process and had } 180,000 \text { subscribers within one year } \\
\text { after the product was launched. }\end{array}$ \\
\hline $\begin{array}{l}\text { Wattanasu } \\
\text { pachoke }\end{array}$ & 2012 & $\begin{array}{l}\text { Companies } \\
\text { listed on the } \\
\text { Stock } \\
\text { Exchange of } \\
\text { Thailand }\end{array}$ & 114 & Thailand & Correlation & $\begin{array}{l}\text { Focus on design } \\
\text { thinking strategies } \\
\text { (managers' } \\
\text { evaluation) }\end{array}$ & & & $\begin{array}{l}\text { Firm innovativeness and } \\
\text { firm performance } \\
\text { compared to competition } \\
\text { over the past three years }\end{array}$ & & $\begin{array}{l}\text { There was a significant positive correlation between the focus on } \\
\text { design thinking strategies and firm innovativeness. Firm } \\
\text { performance correlated with innovativeness but not with focus on } \\
\text { design thinking. }\end{array}$ \\
\hline
\end{tabular}


Research Stream 3

\begin{tabular}{|c|c|c|c|c|c|c|c|c|c|c|c|}
\hline \multirow{3}{*}{ Author(s) } & \multirow{3}{*}{ Year } & \multirow{2}{*}{\multicolumn{3}{|c|}{ Sample }} & \multirow{3}{*}{ Analysis } & \multirow{2}{*}{\multicolumn{5}{|c|}{ Design Success Variables }} & \multirow{3}{*}{ Selected Findings } \\
\hline & & & & & & & & & & & \\
\hline & & Description & Size & Region & & $\begin{array}{l}\text { Design as } \\
\text { Part of an } \\
\text { Organ. }\end{array}$ & $\begin{array}{c}\text { Design as Part of } \\
\text { an } \\
\text { Output }\end{array}$ & $\begin{array}{l}\text { Design-led } \\
\text { Response }\end{array}$ & $\begin{array}{l}\text { Design-led } \\
\text { Organizational } \\
\text { Performance }\end{array}$ & $\begin{array}{l}\text { Design- } \\
\text { led S. R. }\end{array}$ & \\
\hline Berkowitz & 1987 & Homemakers & 288 & USA & $\begin{array}{c}\text { Chi-square } \\
\text { test }\end{array}$ & & $\begin{array}{l}\text { Visual appeal of } \\
\text { frozen corncobs }\end{array}$ & Product preference & & & $\begin{array}{c}\text { Respondents preferred the untrimmed shape of } \\
\text { corncobs mainly due to size of the ears (value for } \\
\text { money) and the perceived better taste. In addition, } \\
\text { some respondents found the untrimmed shape more } \\
\text { aesthetic. }\end{array}$ \\
\hline $\begin{array}{l}\text { Bloch, } \\
\text { Brunel and } \\
\text { Arnold }\end{array}$ & 2003 & $\begin{array}{l}\text { Undergraduate } \\
\text { business students }\end{array}$ & 108 & n.a. & $\begin{array}{l}\text { Conjoint } \\
\text { analysis }\end{array}$ & & $\begin{array}{l}\text { Aesthetic quality of } \\
\text { bathroom scales }\end{array}$ & Purchase intention & & & $\begin{array}{l}\text { Bathroom scale design had a significant influence } \\
\text { on students' purchase intentions. }\end{array}$ \\
\hline $\begin{array}{l}\text { Creusen, } \\
\text { Veryzer } \\
\text { and } \\
\text { Schoorman } \\
\text { s }\end{array}$ & 2010 & $\begin{array}{l}\text { Respondents from a } \\
\text { consumer household } \\
\text { research panel }\end{array}$ & 422 & n.a. & ANOVA & & $\begin{array}{l}\text { Physical appearance } \\
\text { of video recorders }\end{array}$ & $\begin{array}{l}\text { Importance of } \\
\text { aesthetic, ease of use, } \\
\text { quality and number of } \\
\text { functions for building } \\
\text { product preferences }\end{array}$ & & & $\begin{array}{l}\text { Aesthetics and ease of use were most important for } \\
\text { building preferences, followed by quality impression } \\
\text { and number of functions. }\end{array}$ \\
\hline $\begin{array}{l}\text { Dawar and } \\
\text { Parker }\end{array}$ & 1994 & MBA students & 640 & $\begin{array}{l}\text { Industrial } \\
\text { ized } \\
\text { countries }\end{array}$ & ANOVA & & $\begin{array}{l}\text { Physical appearance } \\
\text { of consumer } \\
\text { electronic products }\end{array}$ & $\begin{array}{l}\text { Use of quality signs for } \\
\text { purchasing consumer } \\
\text { electronic products }\end{array}$ & & & $\begin{array}{l}\text { Physical appearance was the third most important } \\
\text { sign of quality for purchasing electronic products, } \\
\text { behind brand name and price and followed by } \\
\text { retailer reputation. }\end{array}$ \\
\hline $\begin{array}{l}\text { Kauppinen- } \\
\text { Räisänen }\end{array}$ & 2010 & Consumers & 18 & n.a. & $\begin{array}{l}\text { Conjoint } \\
\text { analysis }\end{array}$ & & $\begin{array}{l}\text { Colour, shape and } \\
\text { font type of non- } \\
\text { prescriptive drug } \\
\text { packages } \\
\end{array}$ & Product preference & & & $\begin{array}{l}\text { The design of nonprescription drug packages and } \\
\text { throat medicine packages had a significant influence } \\
\text { on consumers' product preferences. }\end{array}$ \\
\hline \multirow[t]{2}{*}{$\begin{array}{l}\text { Orth and } \\
\text { Malkewitz }\end{array}$} & \multirow[t]{2}{*}{2008} & $\begin{array}{l}\text { Members of a } \\
\text { research panel }\end{array}$ & 268 & USA & ANOVA & & $\begin{array}{l}\text { Prototypical, holistic } \\
\text { wine bottle design } \\
\text { classified by several } \\
\text { design features }\end{array}$ & $\begin{array}{l}\text { Brand personality } \\
\text { impression and } \\
\text { managerially oriented } \\
\text { brand impression } \\
\end{array}$ & & & $\begin{array}{c}\text { There were significant differences among consumer } \\
\text { responses to the holistic package designs for both } \\
\text { brand personality impressions and managerially } \\
\text { based impressions. }\end{array}$ \\
\hline & & $\begin{array}{l}\text { Members of a } \\
\text { research panel }\end{array}$ & 108 & n.a. & ANOVA & & $\begin{array}{l}\text { Prototypical, holistic } \\
\text { fragrance package } \\
\text { design }\end{array}$ & $\begin{array}{l}\text { Brand personality } \\
\text { impression }\end{array}$ & & & $\begin{array}{l}\text { There were significant differences among the } \\
\text { personality dimensions consumers attached to } \\
\text { various holistic package designs. }\end{array}$ \\
\hline $\begin{array}{l}\text { Page and } \\
\text { Herr }\end{array}$ & 2002 & Undergraduates & 80 & n.a. & $\begin{array}{l}\text { Logistic } \\
\text { regression }\end{array}$ & & $\begin{array}{l}\text { Aesthetic quality of } \\
\text { laptop computers }\end{array}$ & $\begin{array}{l}\text { Product liking and } \\
\text { quality judgements }\end{array}$ & & & $\begin{array}{l}\text { Aesthetics had a positive influence on participants' } \\
\text { liking and quality judgements. }\end{array}$ \\
\hline $\begin{array}{l}\text { Pantin- } \\
\text { Sohier }\end{array}$ & 2009 & Students & 638 & n.a. & MANOVA & & $\begin{array}{l}\text { Colour and shape of } \\
\text { tins of coffee and } \\
\text { water bottles }\end{array}$ & $\begin{array}{l}\text { Brand personality traits } \\
\text { and brand beliefs }\end{array}$ & & & $\begin{array}{l}\text { The shapes and colours of tins and bottles } \\
\text { significantly influenced several brand personality } \\
\text { traits and brand beliefs. The influence differed } \\
\text { between product categories. }\end{array}$ \\
\hline $\begin{array}{l}\text { Quester } \\
\text { and Smart }\end{array}$ & 1998 & $\begin{array}{l}\text { Wine experts and } \\
\text { managers }\end{array}$ & 20 & n.a. & $\begin{array}{c}\text { Descriptive } \\
\text { analysis }\end{array}$ & & $\begin{array}{l}\text { Features of wine } \\
\text { bottles }\end{array}$ & Product purchase & & & $\begin{array}{c}\text { Twelve respondents mentioned front label, four back } \\
\text { label and three bottle shape as influencing their } \\
\text { purchase decision. }\end{array}$ \\
\hline $\begin{array}{l}\text { Yamamoto } \\
\text { and } \\
\text { Lambert }\end{array}$ & 1994 & $\begin{array}{l}\text { Engineers, purchasing } \\
\text { professionals and } \\
\text { marketing personal }\end{array}$ & 33 & n.a. & $\begin{array}{l}\text { Conjoint } \\
\text { analysis }\end{array}$ & & $\begin{array}{l}\text { Aesthetic quality of } \\
\text { industrial products }\end{array}$ & Product preference & & & $\begin{array}{l}\text { The aesthetic quality of industrial products had a } \\
\text { "palpable" influence on professionals' product } \\
\text { preferences. }\end{array}$ \\
\hline $\begin{array}{l}\text { Yang and } \\
\text { Raghubir }\end{array}$ & 2005 & Consumers & - & n.a. & $\begin{array}{l}\text { Regression } \\
\text { analysis }\end{array}$ & & $\begin{array}{l}\text { Elongation of beer } \\
\text { containers }\end{array}$ & Purchase quantity & & & $\begin{array}{l}\text { More elongated beer containers generated less } \\
\text { purchase quantity than less elongated containers. }\end{array}$ \\
\hline
\end{tabular}


Research Stream 3 (continued)

\begin{tabular}{|c|c|c|c|c|c|c|c|c|c|c|c|}
\hline \multirow{2}{*}{ Author(s) } & \multirow{2}{*}{ Year } & \multicolumn{3}{|c|}{ Sample } & \multirow{2}{*}{ Analysis } & \multicolumn{5}{|c|}{ Design Success Variables } & \multirow{2}{*}{ Selected Findings } \\
\hline & & Description & Size & Region & & $\begin{array}{l}\text { Design as } \\
\text { Part of an } \\
\text { Organization }\end{array}$ & $\begin{array}{l}\text { Design as Part } \\
\text { of an } \\
\text { Output }\end{array}$ & $\begin{array}{l}\text { Design-led } \\
\text { Response }\end{array}$ & $\begin{array}{l}\text { Design-led } \\
\text { Organizational } \\
\text { Performance }\end{array}$ & $\begin{array}{l}\text { Design- } \\
\text { led Share- } \\
\text { holder } \\
\text { Return }\end{array}$ & \\
\hline \multirow{3}{*}{ Dawton } & \multirow{3}{*}{2011} & $\begin{array}{l}\text { Food } \\
\text { company }\end{array}$ & 1 & UK & $\begin{array}{l}\text { Descriptive } \\
\text { analysis }\end{array}$ & & $\begin{array}{c}\text { New package } \\
\text { design }\end{array}$ & & $\begin{array}{l}\text { Brand value, sales } \\
\text { and number of } \\
\text { new customers }\end{array}$ & & $\begin{array}{l}\text { After the change of the package design, sales of the product } \\
\text { range grew by } 16 \% \text {. After a year the brand was worth half a } \\
\text { billion pounds and had attracted } 400 \text { new customers. }\end{array}$ \\
\hline & & Brewery & 1 & Ireland & $\begin{array}{l}\text { Descriptive } \\
\text { analysis }\end{array}$ & & $\begin{array}{l}\text { New package } \\
\text { design }\end{array}$ & & $\begin{array}{l}\text { Sales, profitability } \\
\text { and market share }\end{array}$ & & $\begin{array}{l}\text { The design investment paid off within } 2.8 \text { days comparing the } \\
\text { money spend on design and the increase in sales and } \\
\text { profitability. In turn, market share increased by } 1.4 \% \text {. }\end{array}$ \\
\hline & & Tour operator & 1 & Scotland & $\begin{array}{l}\text { Descriptive } \\
\text { analysis }\end{array}$ & & $\begin{array}{l}\text { New design of } \\
\text { marketing } \\
\text { materials, tour } \\
\text { brochures and } \\
\text { shop signage } \\
\end{array}$ & & $\begin{array}{l}\text { Sales and return } \\
\text { on Investment }\end{array}$ & & $\begin{array}{c}\text { Shop sales grew by } 40 \% \text {, agent sales by } 200 \% \text { and online sales } \\
\text { by } 50 \% \text {. Return on investment was achieved after a month and } \\
\text { yearly revenues increased by } 60 \% \text {. }\end{array}$ \\
\hline $\begin{array}{l}\text { Hoffer and } \\
\text { Reilly }\end{array}$ & 1984 & $\begin{array}{c}\text { Car lines of } \\
\text { US automobile } \\
\text { manufacturer }\end{array}$ & 26 & USA & T-test & & $\begin{array}{l}\text { Degree of cars' } \\
\text { body style } \\
\text { change }\end{array}$ & & Sales growth & & $\begin{array}{l}\text { Car lines with major styling changes were found to have } \\
\text { significantly higher growth rates than car lines with minor styling } \\
\text { changes. }\end{array}$ \\
\hline \multirow{3}{*}{$\begin{array}{l}\text { Landwehr, } \\
\text { McGill and } \\
\text { Herrmann }\end{array}$} & \multirow{3}{*}{2011} & $\begin{array}{l}\text { People within } \\
\text { a given } \\
\text { income range }\end{array}$ & 263 & n.a. & ANOVA & & $\begin{array}{l}\text { Shape of car } \\
\text { fronts }\end{array}$ & Liking & & & $\begin{array}{l}\text { People's liking of car front shapes was significantly higher for } \\
\text { cars with an upturned grille and slanted headlights than cars with } \\
\text { a downturned grille and arched headlights. }\end{array}$ \\
\hline & & $\begin{array}{c}\text { Cars with } \\
\text { major share of } \\
\text { sales in } \\
\text { Germany in } \\
2008 \\
\end{array}$ & 123 & $\begin{array}{c}\text { German } \\
y\end{array}$ & ANOVA & & $\begin{array}{l}\text { Shape of car } \\
\text { fronts }\end{array}$ & & Sales & & $\begin{array}{l}\text { Sales were significantly higher for cars with an upturned grille and } \\
\text { slanted headlights than for cars with a downturned grille and } \\
\text { arched headlights. }\end{array}$ \\
\hline & & $\begin{array}{l}\text { Consumers } \\
\text { assembled by } \\
\text { research } \\
\text { company }\end{array}$ & 146 & n.a. & ANOVA & & $\begin{array}{l}\text { Shape of mobile } \\
\text { phone covers }\end{array}$ & Liking & & & $\begin{array}{l}\text { Consumers' liking of mobile phone shapes was significantly } \\
\text { higher for mobile phones with upturned and slanted buttons than } \\
\text { mobile phones with downturned and arched buttons. }\end{array}$ \\
\hline $\begin{array}{l}\text { Talke, } \\
\text { Salomo, } \\
\text { Wieringa } \\
\text { and Lutz }\end{array}$ & 2009 & $\begin{array}{l}\text { Cars launched } \\
\text { between } 1978 \\
\text { and } 2006\end{array}$ & 157 & $\begin{array}{c}\text { German } \\
y\end{array}$ & $\begin{array}{c}\text { Regression } \\
\text { analysis }\end{array}$ & & $\begin{array}{l}\text { Design newness } \\
\text { of cars }\end{array}$ & & Sales & & Design newness had a significant, positive influence on sales. \\
\hline
\end{tabular}




\section{Appendix 2 - Overview of Avenues for Further Investigations}

\begin{tabular}{|c|c|c|}
\hline Research stream & Current insights & Future research avenues \\
\hline $\begin{array}{l}\text { 1. Design } \\
\text { management }\end{array}$ & $\begin{array}{l}\text { Design emphasis and design excellence have a positive } \\
\text { influence on firms' innovativeness and financial performance. }\end{array}$ & $\begin{array}{l}\text { - How do successful design-driven organizations } \\
\text { incorporate design into their organizational structures and } \\
\text { processes? } \\
\text { - How does design emphasis or design excellence lead to } \\
\text { financial success? } \\
\text { - To what extent does design as part of an organization } \\
\text { influence non-financial performance outcomes? }\end{array}$ \\
\hline 2. Design thinking & $\begin{array}{l}\text { The design thinking process seems to be beneficial for designers } \\
\text { and non-designers working on tangible and intangible tasks alike. }\end{array}$ & $\begin{array}{l}\text { - Can the benefits of design thinking be empirically } \\
\text { validated? } \\
\text { - How should the design thinking process be } \\
\text { operationalized (i.e., which prototyping tools should be } \\
\text { used) to yield the best outcomes? } \\
\text { - Which industries or types of tasks benefit from design } \\
\text { thinking most? } \\
\text { Do theoretical considerations from the design thinking } \\
\text { discourse add to a holistic understanding of the benefits of } \\
\text { design assessed in the design management literature? }\end{array}$ \\
\hline 3. Design output & $\begin{array}{l}\text { An appealing product design improves the chance of a product to } \\
\text { be preferred or bought. }\end{array}$ & $\begin{array}{l}\text { - To what extent does the aesthetic, functional or } \\
\text { communicative aspect of design in isolation influence } \\
\text { consumer preferences? } \\
\text { - How do senses, cultures, demographics and product } \\
\text { types influence the impact of design on consumers? } \\
\text { - Which design outcomes apart from consumer responses } \\
\text { are influenced by design outputs? } \\
\text { - To what extent are intangible design outputs beneficial for } \\
\text { organizations? }\end{array}$ \\
\hline
\end{tabular}


CHAPTER 3. DESIGN ORIENTATION OF FIRMS:

CONCEPTUALIZATION AND EMPIRICAL

INVESTIGATION OF ITS ANTECEDENTS AND

INNOVATION OUTCOMES

A manuscript based on this chapter has been submitted for publication in Research Policy, with the following bibliographic reference: Dülfer, N., Mahr, D., and Wetzels, M. (2014). Design orientation of firms: Conceptualization of its antecedents and innovation outcomes. 


\section{Introduction}

Organizations increasingly view design orientation as an opportunity for distinctiveness and ultimately as a source of competitive advantage and market success (Calabretta et al., 2008; Candi, 2010; Hoegg et al., 2010; Verganti, 2009). An organization's design orientation encompasses design processes, principles and tools that transcend a firm's culture, innovation relevant processes, and strategic decisions to seize a competitive advantage (see Beverland and Farrelly, 2007; Calabretta et al., 2008 for related discussion). This view reflects the shift from design as a specialized function in a firm toward a strategic approach in its innovation management (Perks et al., 2005).

The success of design oriented companies (e.g., Apple in the high tech or Alessi in the kitchenware industry) encourages not only more firms to apply design processes encompassing user observation and idea prototyping to various innovation contexts (Brown, 2009; Martin, 2011), it also encourages policy makers in the United States, China, and the European Union (Beckman and Barry, 2007; European Commission, 2009a) to develop programs to support design capabilities of firms. Yet generalizable findings are limited on what fosters firms' integration of design processes, principles and tools into their innovation management and on the extent to which it leads to financial success (European Commission, 2009a). Thus, both managers and policy makers would benefit from a better understanding of a firm's design orientation and an empirical investigation of its practices to develop innovations more successfully.

Research has equally acknowledged the shift from a product-, object-centered perspective on design toward a cultural and processual perspective (Beckman and Barry, 2007; Brown, 2009). Thus, rather than focusing on the improvement of a product's shape, color, or material (e.g., Bloch, 1995), researchers are increasingly examining organizations' adoptions of design 
principles (e.g., developing a holistic user understanding, visualizing new possibilities, and involving multiple stakeholders), of design processes (i.e. user observation, brainstorming and idea prototyping\& testing), and of design tools (e.g., customer journeys, story boards, research diaries) (Brown, 2009; Liedtka, 2011; Martin, 2009). Such a design orientation is embedded in the entire organization, rather than driven solely by designers, in line with the recently advocated broader view when studying design (Candi, 2007; Moultrie and Livesey, 2014). Yet the changing perspectives on design over time have nourished inconsistencies in the understanding of design orientation, which in turn has resulted in research calls for developing better conceptualizations and testing their impact on firm performance (e.g., Di Benedetto, 2012). Moreover, the topic's novelty in the context of innovation typically confines the empirical work to the project level (e.g., Candi, 2010; Candi and Saemundsson, 2011) and to exploratory, qualitative approaches (e.g. Brown, 2008; Verganti, 2006). To the author's knowledge, no quantitative study provides a fine-grained picture of the internal factors of a firm that facilitate design orientation. This empirical scarcity extends to contextual and industry factors that may serve as boundary conditions Candi and Saemundsson, 2011; Gemser and Leenders, 2001; Solum et al., 1996), but their role remains unclear (Ravasi and Stigliani; 2012; Veryzer and Borja de Mozota, 2005).

To address these research gaps, study 2 adopts a firm perspective to provide a detailed picture of design orientation in the context of innovation management. It addresses the following research questions:

- Which organizational factors drive a firm's design orientation?

- What are the innovation process and financial outcomes of design orientation?

- What are project-, firm-, and industry-related contingency effects for the antecedents and outcomes of design orientation? 
The findings should provide managers and researchers with an empirically validated firmlevel framework that provides guidance for academic or practical efforts of design-led innovation. More specifically, study 2 makes three key contributions to scientific research.

First, this study enriches innovation literature by conceptualizing a firm's design orientation in the context of innovation management. The developed model includes antecedents related to the firm's structure, process, strategy, and culture and its management's commitment as well as outcomes related to its innovation process and financial performance. The generic elements of the model facilitate the comparability of the elements with other prominent conceptualizations of firm processes and culture in innovation (e.g. Cooper and Kleinschmidt, 1995) and marketing (e.g. Kohli and Jaworski, 1990). More generally, the study offers insights into design's role as a lever for a firm's innovation management.

Second, study 2 employs a large-scale data collection to quantitatively validate the developed model and to demonstrate the contribution of design to a firm's innovation management. To the author's knowledge, this data set represents the first large-scale survey of firms to assess firm antecedents and innovation outcomes of design orientation.

Third, this study offers theoretical and empirical insights into boundary conditions for the integration of design orientation into innovation management. In doing so, it supports industry leaders and policy makers in assessing the usefulness of design efforts across various contexts. Moreoever, the findings relate design orientation to prominent research domains such as radical, open, and service innovation and show their contingency effects on design orientation.

The remainder of chapter 3 is structured as follows. After a review of the extant theoretical concepts of design orientation, we develop a model and hypotheses including five firm factors driving design orientation and in turn driving innovation performance. Next, we test the 
model with firm-level data from 986 companies across various industries. After presenting the results, we discuss the findings against the backdrop of prior research and present theoretical and managerial implications. The chapter concludes with a discussion of the study's limitations, which in turn offer suggestions for further research.

\section{Theoretical Background and Hypotheses Development}

\section{Conceptualization of Design Orientation}

Previous descriptions of design orientation reflect the particular design focus of the decade in which the research was conducted (cf. Beverland and Farrelly, 2007; Calabretta et al., 2008; Hart et al., 1989; Kotler and Rath, 1984; Moultrie and Livesey, 2014; Venkatesh et al., 2012). Hart et al. (1989, p. 103), for example, define design orientation "as the realization that competitive advantage can be built on products." In doing so, they highlight the potential of design as an added value to tangible offers. In line with the evolution of design (for related discussion, see Brown, 2009), more recent interpretations of design orientation focus predominantly on design processes and tools for both tangible and intangible innovation outputs (e.g., Beverland and Farrelly, 2007; Calabretta et al., 2008; Moultrie and Livesey, 2014; Venkatesh et al., 2012). Furthermore, Beverland and Farrelly (2007) point out that design oriented firms are not necessarily driven by designers but rather embed design principles throughout the organization, which is in line with the emerging literature on design thinking in the context of business transformation (e.g., Liedtka 2011; Martin, 2011; Wattanasupachoke, 2012). Building on this view, Calabretta et al. (2008, p. 384) highlight that a design orientation reflects a company's use of design "as a major force for innovativeness," which mirrors scholars' increasing interest in the design innovation interface (e.g., Candi, 2010; Candi and Saemundsson, 2011; Moultrie and Livesey, 2014; Verganti, 2009). In line with these recent interpretations, the current study defines design orientation as 
the degree to which a company adopts design principles and applies design processes and tools throughout the innovation process. While the design process typically encompasses user observation, brainstorming and idea prototyping \& testing (Brown, 2009), design principles include - but not exclusively - developing a holistic user experience, visualizing new possibilities, and involving a range of stakeholders (Martin, 2009); popular design tools are customer journeys, story boards, research diaries, stakeholder maps (Brown, 2009; for a more comprehensive listing see Liedtka, 2011). Taking a holistic perspective on design is supported by Candi (2007, p. 561), who suggests "taking a broad view when studying design as an element of innovation."

\section{Antecedents of Design Orientation}

Absent a model that captures the antecedents of design orientation in the context of innovation management, we draw on Cooper and Kleinschmidt's (1995) generic framework, which synthesizes antecedents and outcomes of innovation management. The framework applies to the firm level and is well established, as numerous studies have shown its applicability across various contexts (Holahan et al., 2014). In particular, the authors identify top management's commitment to new product development as well as a strategy, firm organization, the firm's culture, and processes relating to innovation as the fundamental factors that influence its performance (Cooper and Kleinschmidt, 1995). A review of studies on design orientation across the design, innovation, and management literature validated and refined the selected antecedents and informed the hypotheses development for each driver's impact.

\section{Top Management Attitude Toward Innovation}

We contend that a positive top management attitude toward innovation, which represents executive management's appreciation for and promotion of new ideas (cf. Damanpour and 
Schneider, 2006), paves the way for a design orientation. Indeed, the adoption of design principles, which constitute a design orientation, entails a great extent of brainstorming and experimentation to generate and refine ideas (Martin, 2011). However, such design principles are likely to permeate an organization only if top management is supportive of new ideas and its development in general. In a similar vein, Beverland and Farrelly (2007, p. 16) suggest that to create a design oriented company, managers should "become advocates for creativity and design in particular." In line with the foregoing arguments, we hypothesize the following:

\section{H1: A positive top management attitude to innovation facilitates a firm's design orientation.}

\section{Innovation Strategy Implementation}

We anticipate that a design orientation is more likely to occur in a firm with a clear innovation strategy that pervades the organization and sets clear objectives that guide the management of innovation efforts (cf. Noble, 1999). Indeed, an extensive innovation strategy affects the importance placed on not only innovation projects in general but also the involved methods, including those that echo a firm's focus on design (Beverland and Farrelly, 2007; Cooper and Kleinschmidt, 1995). In doing so, the implementation of an innovation strategy sets the foundation for the application of new design tools and the adoption of design principles throughout the organization. Thus, a design orientation is more likely if a clear innovation strategy is more extensively implemented within the company (Beverland and Farrelly, 2007).

Although researchers have implied or assumed a positive relationship between the extensive implementation of an innovation strategy and a design orientation (e.g., Filippetti, 2011), the relationship has not been tested empirically yet. Nevertheless, the authors' conclusions support our argumentation for the following hypothesis:

H2: The implementation of an innovation strategy facilitates a design orientation. 


\section{Organizational Innovation Involvement}

Several authors have already indicated that a design orientation is associated with an organizational innovation involvement (Beverland and Farrelly, 2007; Kotler and Rath, 1984), which represents the simultaneous involvement of different functions and departments in innovation processes (cf. Fredericks, 2005). Han et al. (1998) note that isolated departments are more likely to solve problems in a routine manner than to be creative and take risks. In contrast, interdepartmental work is likely to pave the way for novel ideas because it facilitates drawing from different expertise and combining knowledge in new ways (Zhou et al., 2005). Given that a design orientation, by definition, involves employees discussing and testing new options from different angles, interdepartmental activities provide the structure for employees' collaboration and therefore are likely to foster design orientation. In support of this, several case studies indicate that interdepartmental work is a characteristic of design oriented companies (Beverland and Farrelly, 2007; Calabretta et al., 2008; Moll et al., 2007). Thus, we hypothesize the following:

\section{H3: Organizational innovation involvement facilitates a design orientation.}

\section{Employee Attitude Toward Innovation}

We argue that if design is to transcend an entire organization, it is necessary that employees have a positive attitude toward innovation, which means that they are open and curious regarding new ideas (Hurley and Hult, 1998). In fact, the adoption of design principles and an application of design processes and tools throughout the innovation process requires staff members to experiment and prototype when generating and refining new ideas (cf. Rampino, 2011). In contrast, if employees tend to reject new ideas, regardless of their potential, this mind-set is likely to conflict with design orientation and thus hinder its implementation. In a similar vein, Beverland and Farrelly (2007, p. 10) hint that design oriented firms demonstrate 
a "culture that values curiosity." We select employee's attitude among the factors that constitute a corporate culture (Clemente and Greenspan, 1999) because it best reflects employee's "openness" toward new ideas (cf. Hurley and Hult, 1998; Zhou et al., 2005), and hypothesize the following:

H4: A positive employee attitude toward innovation facilitates a design orientation.

\section{Formalization of the Innovation Process}

We anticipate that higher degrees of a formalized innovation process support the adoption of design principles and the application of design processes and tools. We define formalization of the innovation process according to Kohli and Jaworski (1990, p. 10) as "the degree to which rules define roles, authority relations, communications, norms and sanctions, and procedures." In that sense, formalization provides a guideline for project management and improves prioritization (Cooper and Kleinschmidt, 1991), so that a more formal innovation process also manifests the role of design principles and tools. In turn, formalization may help overcome resistance within a company and therefore facilitate design processes' implementation throughout the organization. In this vein, Calabretta et al. (2008, p. 388) suggest that in design oriented companies, "employees know what their objectives are and to whom they have to report," which can be interpreted as a result of formalization. Thus, we hypothesize the following:

H5: A formal innovation process facilitates a design orientation.

\section{The Moderating Role of External Innovation Collaboration}

Focusing on potential contingency effects, we argue that external innovation collaboration, defined as the intensity of relationships with external sources (cf. Grimaldi et al., 2013), diminishes the firm factors' positive influences on design orientation. Specifically, the application of design processes often serves as a central element to gather and interpret 
customer and market information, which can spur innovation in general and ideation in particular (Beverland and Farrelly, 2007; Martin, 2011). Yet if the innovation management stresses collaborations through external relationships, information or even ideas for new offers are directly brought to a firm's attention, so that the value of design processes as information hubs decreases. In turn, the firm factors are less likely to foster a design orientation and are rather more likely to support an "open innovation" approach, that is not (only) based on design processes (Mahr et al., 2014). More specifically, top management's favor for new ideas may drive the development of open innovation platforms to gather customers' ideas rather than the implementation of design processes, which involve gathering customer information on the basis of which ideas are generated within the firm (Mortara et al., 2009). In a similar vein, employees' positive attitude toward innovation might foster the search for ideas from outside the organization rather than internally developing their own ideas. Implementing an innovation strategy and formalizing the innovation process could both pave the way for intensive collaborations rather than the application of design tools. Finally, organizational innovation involvement might extend outside the company rather than build a foundation for design orientation.

Hinting at such a contingency effect, Filippetti's (2011) cluster analysis reveals that although the use of design and collaboration with external partners can coexist (see also Moll et al., 2007), the latter approach seems to shift the focus on design toward an open innovation approach, whereby design principles are neglected. Thus, we hypothesize the following:

H6: Higher degrees of external innovation collaboration reduce the positive influence of (a) top management's attitude toward innovation, (b) innovation strategy implementation, (c) organizational innovation involvement, (d) employee attitude toward innovation, and (e) formalized innovation processes on design orientation. 


\section{Design Orientation as a Driver of Innovation Outcomes}

In the present study, innovation outcomes encompass financial innovation returns as well as innovation process effectiveness and efficiency. Design-related performance studies predominantly use financial returns (e.g., Black and Baker, 1987; Hertenstein et al., 2001; Solum et al., 1996), whereas the latter two categories are often used in innovation contexts (e.g., Hoegl and Gemuenden, 2001; Sivasubramaniam et al., 2012). By integrating these categories, we aim to provide a more complete and fine-grained understanding of how design orientation influences innovation performance outcomes. Moreover, we aim to shed more light on the interrelationships between the dependent variables used in previous studies. In the following subsections, we explain the hypothesized influences of design orientation on those constructs and their interrelationships.

\section{The Influence of Design Orientation on Financial Innovation Returns}

We argue that design orientation is likely to improve financial innovation returns, which capture the extent to which innovations contribute to overall company performance (Solum et al., 1996; Cooper and Kleinschmidt, 1995). Research shows that paying attention to design can add value to innovation outputs from the aesthetic, functional, or communicative perspective (Veryzer, 1995) and in turn improve people's responses toward innovations in terms of product liking (e.g., Page and Herr, 2002) or purchase behavior (e.g., KauppinenRäisänen, 2010) in a variety of contexts, such as industrial products (Yamamoto and Lambert, 1994) or services (Candi and Saemundsson, 2011). Those results support the common assumption that design outputs can help differentiate offerings in the market and develop competitive advantages (Kotler and Rath, 1984; Veryzer and Borja de Mozota, 2005). Given these findings, design orientation is likely to improve financial innovation returns due to possible higher margins or increased sales volume of new offerings. 
Although Solum et al. (1996) demonstrate that the share of sales from innovation increases with greater design investment, their analysis does not uncover how design investment affects the innovation process. Yet, anecdotal evidence shows that the use of design principles during the innovation process can increase financial performance (Martin, 2009). Although these studies underpin the general notion of design as a driver of financial returns, none of them has focused on design as an orientation transcending firms and their management levels. Hence, we hypothesize the following:

\section{H7: Design orientation has a positive influence on financial innovation returns}

\section{The Mediating Effect of Innovation Process Effectiveness}

The impact of design orientation on financial returns may be partially mediated by innovation process effectiveness, which we define as the degree to which ideas, concepts, and marketready products are commercialized (cf. Wattanasupachoke, 2012). Design processes are often valued for spurring the identification of market opportunities by observing the environment and testing existing solutions (Acklin, 2010; Borja de Mozota, 2003; Filippetti, 2011). Moreover, researchers view design methods such as brainstorming and prototyping as enhancing the ideation process and the exploitation of resulting ideas into marketable solutions (e.g. Martin, 2011). Thus, design oriented companies are more likely to show higher degrees of innovation process effectiveness, as more market opportunities are identified on the one hand and a greater share of ideas are transformed into marketable solutions on the other. In turn, the increased commercialization of innovation outputs may enhance financial innovation returns given that more markets can be served by a greater number of innovations compared with less design oriented companies.

The findings of the UK Design Council (2007) hint at the assumed relationships: companies that view design as an integral part of their operations are more likely to launch new products 
and services and approximately twice as likely to show a rapid growth in turnover (UK Design Council, 2007). To further examine these stepwise findings, we hypothesize the following mediation:

H8: The influence of design orientation on financial innovation returns is partially mediated by innovation process effectiveness.

\section{The Mediating Effect of Innovation Process Efficiency}

The impact of design orientation on financial returns may furthermore be mediated by innovation process efficiency, which reflects the extent to which innovation projects meet predefined time-, budget-, quality-, and launch-specific targets (cf. Hoegl and Gemuenden, 2001). Research demonstrates that design tools span language boundaries in interdisciplinary teams and ensure that each team member understands what the final innovation output will be (e.g., by increasing team communication, visualizing ideas, and building prototypes throughout the innovation process; Borja de Mozota, 2003; Woodward, 2010). Potential problems with the resulting innovation (e.g., limited suitability for efficient mass production) can be detected early on in the development process, which reduces the risk of redevelopment (Calabretta et al., 2008; Design Council, 2008) and increases the likelihood of meeting time, quality, and cost targets (Borja de Mozota, 2006; Calabretta et al., 2008). In particular, early prototyping is likely to increase the likelihood of meeting customer needs and subsequently specific launch targets, in that prototyping enables a more realistic testing of future offers that people are not able to imagine (Mahr and Lievens, 2012).

The enhanced innovation process efficiency is in turn likely to drive financial innovation returns as less redevelopment reduces costs and a better fit with market needs increases sales volume while reducing the chances of costly failures on the market (Chiva et al., 2004). In line with these arguments, Lindström and Pajarinen (2006) indicate that the intensity of a 
company's design orientation is associated with not only increased production efficiency but also decreased production costs and increased sales; however, a mediation effect has not been tested. Nevertheless, the argumentation and these initial findings lead us to hypothesize the following:

H9: The influence of design orientation on financial innovation returns is partially mediated by innovation process efficiency.

\section{The Moderating Effects of Product Relatedness}

Although there is increasing evidence that design processes, principles and tools can be beneficial for various innovation outputs apart from tangibles (e.g., Brown, 2008; Candi and Saemundsson, 2011; Hempel, 2007; Martin, 2011), design may still unfold its largest potential for product innovations rather than intangible offers, such as new services or business models. For these intangible and even invisible forms of innovation outputs, not all common design tools might be easily applicable, at least not without reinterpreting or at least adapting them (cf. Brown, 2008; Martin, 2011). Proper prototyping of services, for example, requires scenario-building techniques based on storyboards, flowcharts, or role play (Fulton Suri and Marsh, 2000; Gattiker, 2012), which might not be present in all companies. Therefore, design orientation is more likely to enhance innovation process efficiency for companies with predominantly product innovation projects, for which design tools are more easily applicable by all staff members. Following this argument, the benefits of a firm's design orientation in identifying market needs and generating ideas, as reflected by the innovation process effectiveness, is likely to be greater for product innovations than for service or business model innovations. In line with this rationale, Filippetti's (2011) results suggest that the design oriented company clusters are associated more closely with product 
rather than with service innovations. Thus, we hypothesize the following:

H10: A stronger focus on product-related as opposed to non-product-related innovations increases the impact of design orientation on (a) financial innovation returns, (b) innovation process effectiveness, and ( c) innovation process efficiency.

\section{The Moderating Effects of Innovation Radicalness}

Focusing on the direct impact of design orientation on financial innovation returns, we expect a stronger influence for companies that focus predominantly on incremental rather than radical innovations, which we describe as gradual improvements as opposed to breakthrough innovations (cf. Perks et al., 2005). In particular, we argue that design adds relatively more value to incremental than to radical innovations because the increasing radicalness of innovations may encompass more technical aspects that deflect from design solutions. Thus, customers might conceivably be less affected by the design of radical innovations than that of incremental innovations, which in turn reduces design's impact on purchase decisions. Therefore, innovation radicalness could diminish the influence of design orientation on financial innovation returns.

We expect a similar contingency effect for innovation process effectiveness. As we argued previously, design orientation is likely to increase innovation process effectiveness through the resulting closeness to the market and especially the customer (Martin, 2009). However, Verganti (2009) argues that more radical innovations are not a result of user-centered approaches. In particular, referring to a video game console that is based on a controller with an integrated motion sensor, he states that "if Nintendo had closely observed teenagers using existing game consoles, it probably would have improved traditional game controllers, enabling users to better immerse themselves in a virtual world, rather than redefining what a game console is" (p. 10). Thus, the focus on existing solutions as a design principle may to 
some extent hinder the development of more radical innovations, which are by definition further from the preceding solution than incremental innovations. Following this reasoning, design orientation is less likely to enhance the commercialization of ideas and products in companies that predominantly focus on radical rather than incremental innovations.

In contrast to the presumed moderation of the innovation radicalness described previously, opposite moderating effects can be expected with regard to the impact of design orientation on innovation process efficiency. As mentioned previously, innovation is inevitably accompanied by uncertainty regarding internal processes (Han et al., 1998) and the adoption within the market (Design Council, 2008). This uncertainty is likely to increase as radicalness increases, as the internal processes and the adoption within the market are less predictable for higher degrees of newness. Therefore, design methods such as prototyping, which enable teams to envision and test ideas early on, thereby reducing uncertainty, are conceivably a stronger trigger for meeting predefined targets in the context of radical rather than incremental innovations.

Taking these elements together, we hypothesize the following:

H11: A stronger focus on radical rather than incremental innovation decreases the impact of design orientation on (a) financial innovation returns and (b) innovation process effectiveness, but (c) increases the impact of design orientation on innovation process efficiency.

\section{Conceptual Model}

As a summary of the literature review above, the following conceptual model graphically represents the hypothesized relationships 


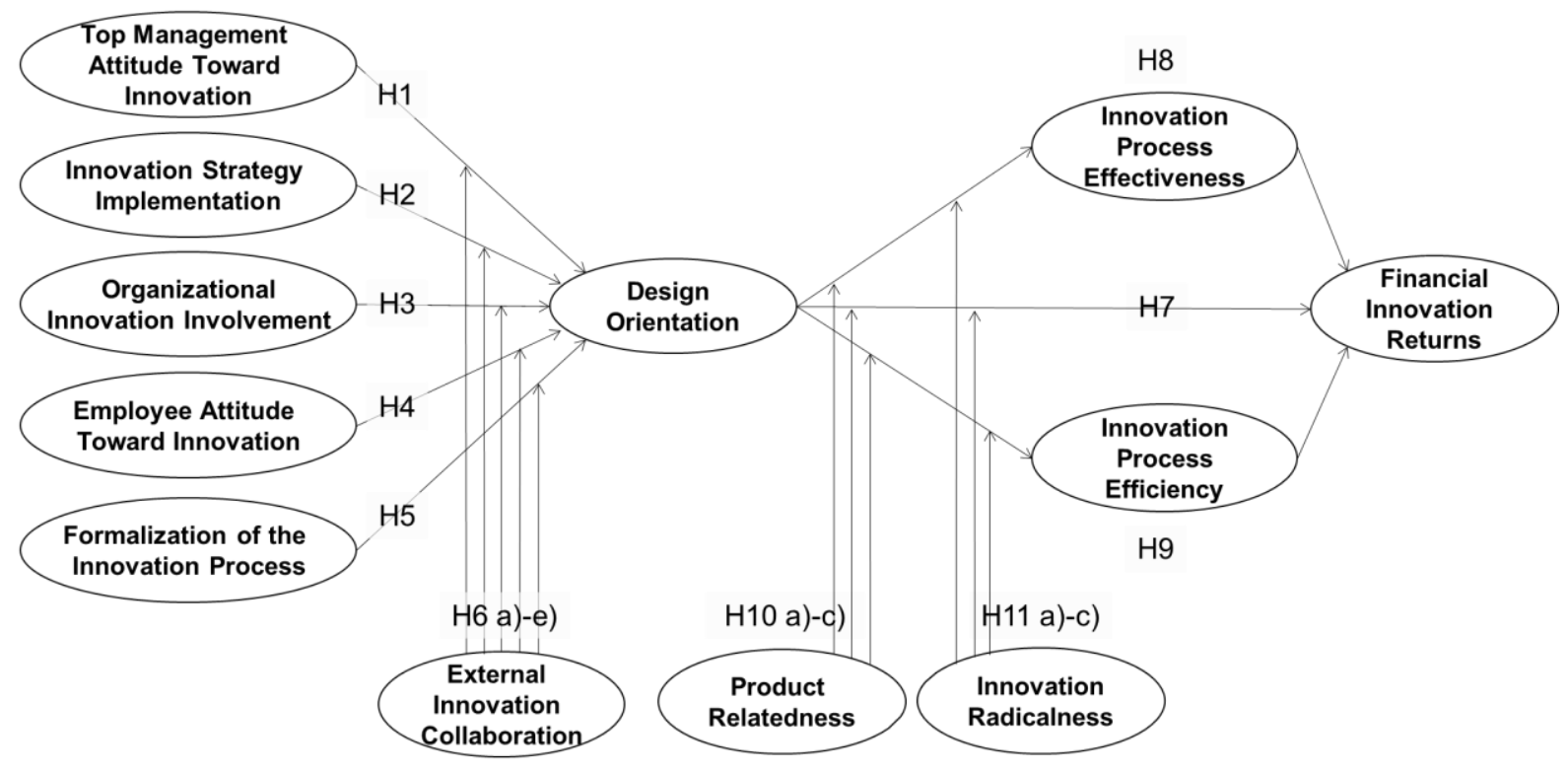

\section{Methodology}

\section{Data Collection and Sample}

The empirical analysis is based on firm-level data that stems from IMP³rove, the European Commission's project for better innovation management support services led by A.T. Kearney (https://www.improve-innovation.eu/). The IMP ${ }^{3}$ rove project was initiated by the European Commission (DG Enterprise and Industry) to enhance European small and mediumsized enterprises' (SMEs') global competitiveness through innovation (Engel et al., 2008). As part of this initiative, a benchmarking database was developed, which captures a wide range of subjective as well as objective measures on individual companies' innovation management practices and performances.

The data used for the analysis was collected between September 2008 and December 2012. Respondents filled out an online survey, which was accessible in eight languages (Czech, 
English, French, German, Italian, Hungarian, Polish, and Spanish) ${ }^{\mathbf{1}}$. Respondents were required to answer each of the 48 questions before proceeding. The software used prevented invalid data entries, such as the sum of entered percentages on a question exceeding the allowed limit of 100. Answers to questions such as "not existent" or "not applicable" were later excluded case wise from the analysis. Each company filled out the questionnaire only once. After completion, each respondent received an automatically generated benchmarking report. The report compared the innovation management performance of the respective company with the averaged results of its competitors or a set of companies with high growth rates. Informants were owners, chief executive officers, or managers of the companies and therefore were viewed as being knowledgeable in answering the questions.

Respondents were targeted directly through communication channels such as presentations, articles, trade fairs or the Internet and indirectly through innovation management consultants. The consultants, who were previously trained by $\mathrm{IMP}^{3}$ rove project members, explained to respondents the purpose of the survey, ensured that they understood the questions during the process, and pointed out potential areas for improvement on the basis of the benchmarking report.

In total, 2,164 respondents began the questionnaire, of whom 1,302 successfully completed it. From the latter set, we excluded 316 cases because they answered affirmatively the item "have never heard of design and design management as a lever for innovation before" and were therefore not able to provide answers on the focal construct design orientation. Thus, the final sample comprised 986 cases which were used for the analysis. The sample reflects the IMP³rove project's initial focus on European SMEs (Engel et al., 2008), as Table 3.1 shows.

\footnotetext{
${ }^{1}$ During the questionnaire development, professional translators and native speakers had been involved in order to ensure the equality of its content.
} 
Table 3.1 Sample Characteristics

\begin{tabular}{|c|c|c|}
\hline Company Age [in Years] & \# cases & $\%$ \\
\hline 10 or fewer & 471 & 47.8 \\
\hline $11-25$ & 333 & 33.8 \\
\hline $26-50$ & 100 & 10.1 \\
\hline $51-100$ & 61 & 6.2 \\
\hline $101-200$ & 20 & 2.0 \\
\hline more than 200 & 1 & 0.1 \\
\hline Income [in thousand EUR] & \# cases & $\%$ \\
\hline 10 or fewer & 79 & 9.0 \\
\hline $11-25$ & 34 & 3.4 \\
\hline $26-100$ & 68 & 6.9 \\
\hline $101-500$ & 165 & 16.7 \\
\hline $501-2,500$ & 250 & 25.4 \\
\hline $2,501-50,000$ & 262 & 26.6 \\
\hline more than 50,000 & 128 & 13.0 \\
\hline Type of Industry & \# cases & $\%$ \\
\hline Bio Tech, Pharmaceutics, Chemical & 96 & 9.7 \\
\hline Food, Beverages & 96 & 9.7 \\
\hline ICT, Electrical, Optical & 163 & 16.5 \\
\hline Knowledge Intensive Services & 324 & 32.9 \\
\hline Machinery, Equipment, Plant Construction & 219 & 22.2 \\
\hline Space, Aeronautics and Automotive & 35 & 3.5 \\
\hline Textile & 53 & 5.4 \\
\hline Number of Employees & \# cases & $\%$ \\
\hline 10 or fewer & 330 & 33.5 \\
\hline $11-25$ & 189 & 19.2 \\
\hline $26-50$ & 153 & 15.5 \\
\hline $51-100$ & 108 & 11.0 \\
\hline $101-200$ & 79 & 8.0 \\
\hline more than 200 & 127 & 12.9 \\
\hline Region & \# cases & $\%$ \\
\hline Africa & 12 & 1.2 \\
\hline Asia & 18 & 1.8 \\
\hline Australia & 42 & 4.3 \\
\hline Europe & 794 & 80.5 \\
\hline North America & 57 & 5.8 \\
\hline South America & 58 & 5.9 \\
\hline Not specified & 5 & 0.5 \\
\hline
\end{tabular}

\section{Measures}

The IMP3rove Consortium, which set up the benchmarking tool mentioned previously, developed the measures. The consortium consisted of members based across Europe such as research institutes and management consultancies. Pilot samples were used to assess the 
measures' applicability to the target group and to check measures' reliability and validity. For this study, we selected reflective multi-item as well as single-item measures. The appendix to this chapter presents a list of all constructs and items used.

\section{Antecedents}

Top management attitude toward innovation encompasses six items, all measured on a sevenpoint Likert scale ( 1 = "not applicable" to 7 = "fully applicable"). The items capture whether top management is excited about innovation, open to new unusual ideas, able to think out of the box, imaginative, able to sell ideas internally, and focusing on business impact.

Innovation strategy implementation consists of three binary-scaled items $(0=$ "not applicable" and $1=$ "applicable"). The items assess whether the innovation strategy sets clear objectives for innovation management activities and projects and whether it provides the basis for organizational changes and business model development.

The three items related to organizational innovation involvement assess how regularly purchasing, marketing and sales, and production/service development groups are involved in the generation of ideas and collection of suggestions for improvement using a seven point rating scale ( $1=$ "not at all" to $7=$ "highly regularly"). A zero was assigned if the respective organizational unit was missing.

For employee attitude toward innovation, we used the same items as those for top management attitude toward innovation but related to the employee attitude.

Formalization of the innovation process encompasses five items and assesses to what degree a formal process is in place for product, service, process, organization, and business model development using a seven-point scale ( $1=$ "not at all" to $7=$ "successfully in place"). 


\section{Focal Construct}

The focal construct design orientation encompasses seven items, all measured on a sevenpoint scale $(1=$ "not at all" to $7=$ "to a very high degree"). The items capture the extent to which design was an integral part of the innovation strategy, design thinking was a driver of the innovation culture, design played an important role during the entire innovation life cycle, and design was important with respect to recruiting and human resource development during the previous three years. Using such a comprehensive interpretation of design is in line with the suggestions of several authors (e.g. Black and Baker, 1987; Candi, 2007; Filippetti, 2011; Roy and Riedel, 1997).

\section{Mediators}

The three items of the innovation process effectiveness construct reflect the extent to which internally developed ideas, concepts, and market ready products were commercialized in terms of selling or licensing using a seven point scale $(1=$ "not at all" to $7=$ "to a high extent"). Innovation process efficiency captures how often innovation projects meet time-, budget-, quality-, and launch-specific targets. The construct encompasses four items, each measured as a share of projects for which targets were defined.

\section{Dependent Variable}

Financial innovation returns were assessed in terms of the average share of both income and operating profit (EBIT) from innovation during the past three years. The profit-related share was estimated by the respondents while the income related share was calculated based on companies' overall income and its income from innovation in absolute terms. A similar construct was used in the design related study by Solum et al. (1996). Furthermore, Cooper and Kleinschmidt (2007) mention those two items among ten key performance metrics in innovation research. 


\section{Moderators}

The three items of external innovation collaboration reflect how much informal relationships with external sources enhance each phase of the innovation life cycle. Each item was measured on a seven-point scale from 1 ("not at all") to 7 ("to a very high degree").

For product relatedness, we created a binary-scaled single item measure. In particular, we assigned 1 to companies that started more product innovation projects and a 0 to companies that started more non-product innovation projects. To assess the number of non-product innovation projects, we calculated the sum of all service, process, organizational, and business model innovation projects. A project was counted, if it had been started within four years of when the questionnaire was filled out. We assessed innovation radicalness similarly: companies that generated a greater number of radical ideas per year were assigned a 1 , and companies with more incremental ideas were assigned a 0 .

\section{Control Variables}

We selected several variables to control for potential extraneous influences that could inflate the relationship between design and financial innovation returns. First, we controlled for the influence of region, because studies have shown that countries' overall competitive rankings are often comparable with their rankings in terms of design (e.g. European Commission, 2009a). Specifically, we created binary scales for Africa, Asia, Australia, Europe, North America and South America, for which we assign a 1 to companies based in the respective region, and a 0 otherwise. Second, we controlled for type of industry using the same approach. Specifically, we created binary scales for bio technology, pharmaceuticals, and chemical; food and beverages; ICT, electrical, and optical; knowledge-intensive service; machinery, equipment, and plant construction; and space, aeronautics, and automotive industries. Empirical results of previous studies indicate that the impact of design on performance 
outcomes is not independent of the industry in which firms compete (e.g. Candi and Saemundsson, 2011; Gemser and Leenders, 2001; Solum et al., 1996). Notably, the dummy coding approach for the control variables region and type of industry requires that the number of categories included in the analysis is one less than the number of categories assessed.

Third, we controlled for company age. According to Borja de Mozota (2002), the influence of design on performance might increase with more design experience. Because it is conceivable that older companies are in general more experienced and thus also with design, we included company age as an integer number (years) in the analysis as a control variable (see Candi, 2010; Candi and Saemundsson, 2011 for related discussion).

Fourth, a comparable study by Candi and Saemundsson (2011) includes a control variable for the influence of firm size in terms of number of employees, which has been shown to influence design emphasis. In line with these findings, we controlled for the number of employees in this study as well.

Fifth, Hertenstein et al. (2001) show that companies demonstrating more rather than less effective design have significantly higher research and development expenditures in relation to net sales ratios. Furthermore, Candi (2010, p. 1059) explains that "if aesthetic design in NSD [new service development] is related to the anticipated benefits, a relationship with the level of NSD effort, or level of innovation effort is also to be expected." Therefore, we use innovation expenditure (in euros) as a control variable in this study.

Sixth, we controlled for the recency of measurement. Because the data was gathered over a longer period, economic up- and downturns might have affected the results. Therefore, we added a binary scaled control variable, whereby we assigned cases filled out during the first half of the data gathering time frame (September 2008-October 2010) a 0, and latter entries (November 2010-December 2012) a 1. 
Finally, we included type of assessment in the analysis as a binary variable. In particular, we assigned cases in which questionnaires were filled out individually a 0 and those that were guided a 1 .

\section{Analysis Approach}

We use SmartPLS 2.0 (Ringle et al., 2005) to obtain partial least squares (PLS) estimates for both the measurement and the structural parameters for structural equation modeling (SEM; Chin 1998). We selected PLS-SEM instead of the traditional covariance-based approach for two particular reasons. First, the influences and outcomes of design orientation are theoretically not well established yet. Therefore, PLS, which focuses on maximizing the variance explained for the endogenous constructs, better suits our prediction-oriented (rather than parameter-oriented) research objective (Chin, 1998; Reinartz et al., 2009). Second, to account for the hypothesized moderation effects, we built latent interaction variables in SmartPLS (Ringle et al., 2005) by multiplying the items of the predictive latent variable with the items of the moderating latent variable (Chin et al., 2003). This procedure increases the complexity of the structural model to a great extent; thus, PLS path modeling is more appropriate from this perspective as well (Chin et al., 2003; Haenlein and Kaplan, 2004).In addition, we used Smart PLS 2.0 (Ringle et al., 2005) to perform its (nonparametric) bootstrapping algorithm with 500 resamples to obtain standard errors based upon which we test the causal relationships within the structural model for statistical significance (Chin, 1998). Next, we describe in more detail the psychometric properties of the measurement instruments, including reliability, convergent validity and discriminant validity (Antioco et al., 2008), a check for common method variance, and the results for the structural model. 


\section{Results}

\section{Measurement Model}

Scale Reliability, Convergent Validity and Internal Consistency

We assessed scale reliability by analyzing the loadings of the items on their respective factors. All loadings were above the threshold level of .5, indicating sufficient reliability. To explore the convergent validity of the reflective multi-item measures, we screened the average variance extracted (AVE) values. All constructs indicated AVE values that exceed .5, except innovation process effectiveness $(\mathrm{AVE}=.47)$, which suggests convergent validity (Fornell and Larcker, 1981). Moreover, we considered the composite reliability (CR) indicators, which range from .73 to .96 and thus are all greater than the recommended minimum of .7 (Fornell and Larcker, 1981), in support of the internal consistency of the measures.

\section{Discriminant Validity}

Next, we compared the square root of each construct's AVE value with the respective construct's correlations with all other latent variables. All square roots exceeded the relevant correlation coefficients, as Table 3.2 shows, which suggests discriminant validity (Fornell and Larcker, 1981; Wetzels et al., 2009). In further support, all latent variable correlations were substantially smaller than 1 (Fornell and Larcker, 1981). 
Table 3.2 Latent Variable Correlations

\begin{tabular}{|c|c|c|c|c|c|c|c|c|c|c|c|c|}
\hline Constructs & 1 & 2 & 3 & 4 & 5 & 6 & 7 & 8 & 9 & 10 & 11 & 12 \\
\hline 1 Top Mgmt. Attitude toward Innov. & $.81^{a}$ & & & & & & & & & & & \\
\hline 2 Innovation Strategy Implementation & .24 & .74 & & & & & & & & & & \\
\hline 3 Organizational Innov. Involvement & .28 & .15 & .75 & & & & & & & & & \\
\hline 4 Employee Attitude toward Innov. & .39 & .15 & .24 & .84 & & & & & & & & \\
\hline 5 Formalization of the Innov. Process & .26 & .19 & .40 & .29 & .80 & & & & & & & \\
\hline 6 External Innovation Collaboration & .28 & .14 & .17 & .24 & .25 & .88 & & & & & & \\
\hline 7 Design Orientation & .32 & .20 & .27 & .23 & .33 & .28 & .88 & & & & & \\
\hline 8 Innovation Radicalness & -.02 & -.03 & -.10 & .04 & .03 & -.01 & .04 & $n / a$ & & & & \\
\hline 9 Product Relatedness & .04 & .05 & .03 & -.03 & -.20 & -.04 & .03 & -.02 & $n / a$ & & & \\
\hline 10 Innovation Process Effectiveness & .28 & .04 & .23 & .35 & .32 & .25 & .26 & .04 & .02 & .69 & & \\
\hline 11 Innovation Process Efficiency & .36 & .18 & .26 & .35 & .31 & .18 & .24 & -.10 & .03 & .18 & .82 & \\
\hline 12 Financial Innovation Returns & .07 & .07 & .07 & .17 & .15 & -.01 & .21 & .07 & .03 & .18 & .10 & .81 \\
\hline Mean & 5.67 & 1.23 & 4.11 & 3.93 & 3.43 & 4.17 & 4.02 & .24 & .35 & 3.41 & 52.8 & 32.5 \\
\hline Standard Deviation & 1.17 & .66 & 1.70 & 1.42 & 1.61 & 1.56 & 1.73 & .43 & .48 & 1.53 & 29.7 & 29.9 \\
\hline AVE & .66 & .55 & .56 & .70 & .64 & .77 & .77 & $\mathrm{n} / \mathrm{a}$ & $\mathrm{n} / \mathrm{a}$ & .47 & .68 & .66 \\
\hline $\mathrm{s}_{2}$ & .92 & .78 & .79 & .93 & .90 & .91 & .96 & $\mathrm{n} / \mathrm{a}$ & $\mathrm{n} / \mathrm{a}$ & .73 & .89 & .79 \\
\hline
\end{tabular}

${ }^{\mathrm{a}}$ The square root of the AVE is on the diagonal; $\mathrm{n} / \mathrm{a}=$ not applicable

\section{Common-Method Bias}

Because the data came from a single source, common method bias may have inflated the constructs; relationships. Therefore, we applied three methods to explore whether common method bias is within acceptable levels. First, we conducted principal component analysis (unrotated; with Varimax rotation) (Podsakoff et al., 2003). The results showed that 12 factors account for $78.9 \%$ of the variance, whereby all items loaded high on the expected dimensions. Furthermore, the first factor captured only $16.7 \%$ of the variance, which suggests that the covariance in the measures cannot be traced back to a single higher- order factor.

Second, we conducted a Schmid-Leiman (SL) transformation (Schmid and Leiman, 1957), which allows for the inclusion of a general ("method") factor (cf. a bifactor model). The general factor accounts for less than $30 \%$ of the variance, which further supports that common method bias does not substantially affect our findings.

Third, we calculated partial correlations between the main constructs while controlling for the effects of a marker variable (Lindell and Whitney, 2001). We used external innovation 
collaboration as a marker, because it showed the weakest correlation with the dependent variable financial innovation returns. A comparison between the initial latent variable correlations and the results from the partial correlations reveals that all initially significant correlations stay significant when it is controlled for the marker variable. Furthermore, the magnitudes of the correlation coefficients remain at comparable levels. Thus, common method bias does not seem to have seriously affected the results.

\section{Structural Model}

\section{Model Fit}

The $\mathrm{R}^{2}$ values reveal that the model explains $22 \%$ of the variance in its focal construct design orientation. The variances in the mediators innovation process effectiveness and innovation process efficiency can be explained by $8 \%$ each. Finally, the model explains $13 \%$ of the variance in the main outcome variable financial innovation returns. Those results are satisfying given that the unit of analysis is the company and objective firm data was used for the outcome variable (Talke et al., 2011).

To find an indication for the model's global goodness-of-fit (GoF), we applied the $\mathrm{R}^{2}$-based equation suggested by Tenenhaus et al. (2005). The so calculated GoF index is .29, which exceeds the cutoff value of .25 for medium effect sizes of $\mathrm{R}^{2}$ (Wetzels et al., 2009).

\section{Effects}

We considered the path coefficients and t-values to draw conclusions about the hypothesized relationships between the latent variables. Table 3.3 summarizes the empirical results. 
Independent Constructs

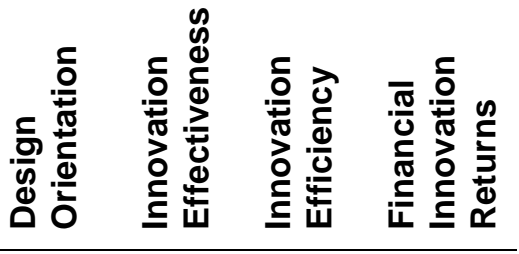

\begin{tabular}{ll} 
Top Management Attitude Toward Innovation & $.16^{\star *}$ \\
Innovation Strategy Implementation & $.09^{\star *}$ \\
Organizational Innovation Involvement & $.07^{\star}$ \\
Employee Attitude Toward Innovation & .05 \\
Formalization of the Innovation Process & $.20^{\star *}$ \\
External Innovation Collaboration & $.15^{\star *}$ \\
Top Management Attitude Toward Inno. x Ext. Inno. Collaboration & .05 \\
Innovation Strategy Implementation x Ext. Inno. Collaboration & $-.07^{*}$ \\
Organizational Innovation Involvement x Ext. Inno. Collaboration & $-.13^{*}$ \\
Employee Attitude Toward Innovation x Ext. Inno. Collaboration & .05 \\
Formalization of the Innovation Process x Ext. Inno. Collaboration & .08 \\
\hline
\end{tabular}

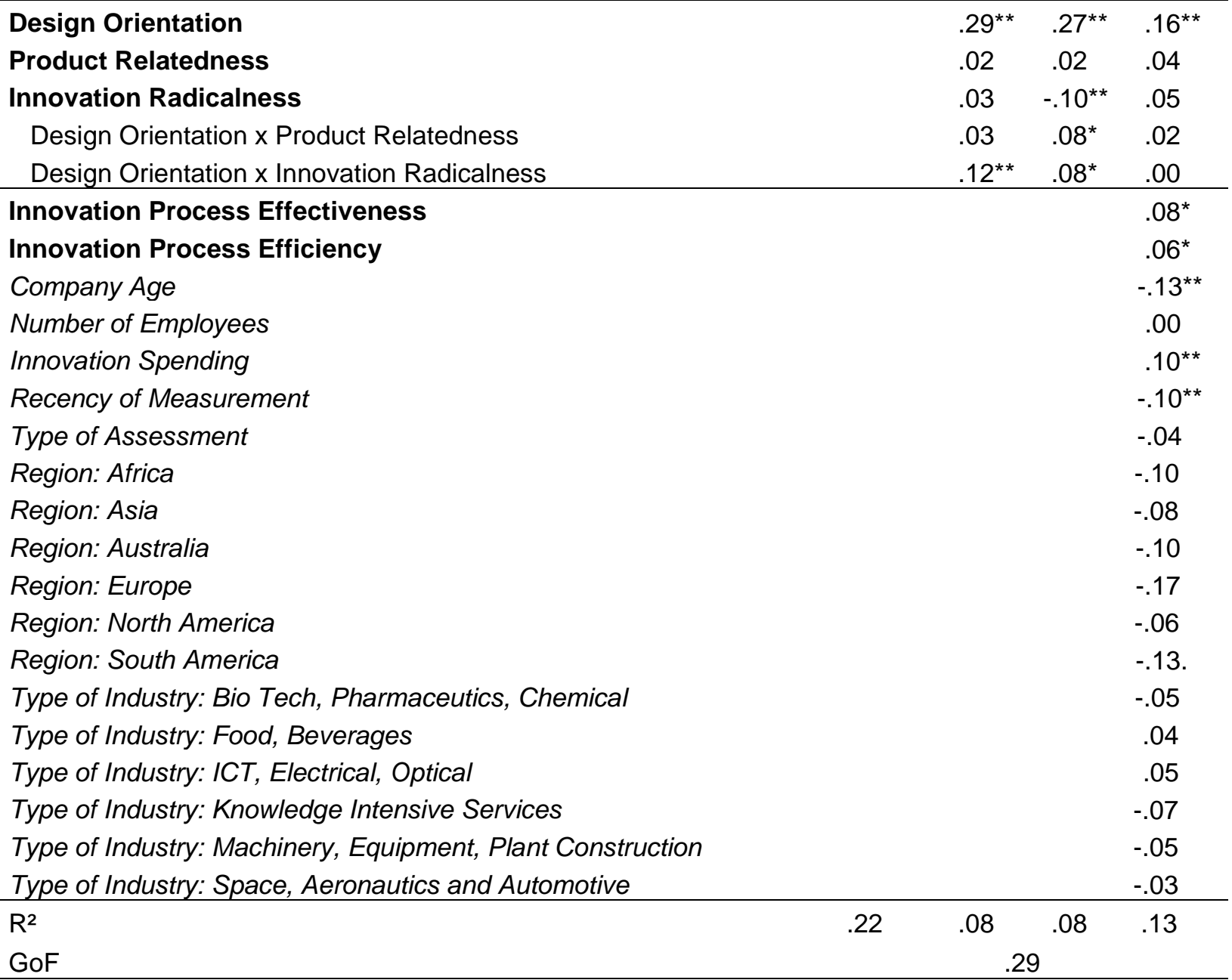

${ }^{* *} p<.01 ;{ }^{*} p<.05$ (all effects one-sided) 
Top management attitude toward innovation, innovation strategy implementation, organizational innovation involvement, and formalization of the innovation process all have a significant positive influence on design orientation. Thus, hypotheses $\mathrm{H} 1, \mathrm{H} 2, \mathrm{H} 3$, and $\mathrm{H} 5$ fail to be rejected (see Table 3.4). However, employee attitude toward innovation does not significantly drive design orientation; therefore, hypothesis 4 is rejected.

\section{Table 3.4 Summary of Hypotheses and Results}

\begin{tabular}{|c|c|c|c|c|}
\hline Hyp. & Path & 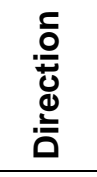 & 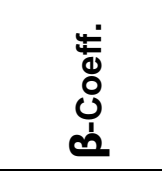 & 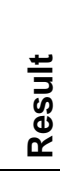 \\
\hline $\mathrm{H} 1$ & Top Management Attitude Toward Innovation $\rightarrow$ DO & + & $.16^{\star \star}$ & $\checkmark$ \\
\hline $\mathrm{H} 2$ & Innovation Strategy Implementation $\rightarrow$ DO & + & $.09^{* *}$ & $\checkmark$ \\
\hline H3 & Organizational Innovation Involvement $\rightarrow$ DO & + & $.07^{*}$ & $\checkmark$ \\
\hline $\mathrm{H} 4$ & Employee Attitude Toward Innovation $\rightarrow$ DO & + & .05 & \\
\hline H5 & Formalization of the Innovation Process $\rightarrow$ DO & + & $.20^{\star *}$ & $\checkmark$ \\
\hline $\mathrm{H} 6 \mathrm{a}$ & Top Management Attitude Toward Innov. x Ext. Inno. Collab. $\rightarrow$ DO & - & .05 & \\
\hline $\mathrm{H} 6 \mathrm{~b}$ & Innovation Strategy Existence x Ext. Inno. Collaboration $\rightarrow$ DO & - & $-.07^{\star}$ & $\checkmark$ \\
\hline H6c & Organizational Innovation Involvement x Ext. Inno. Collaboration $\rightarrow$ DO & - & $-.13^{*}$ & \\
\hline H6d & Staff Attitude Toward Innovation x Ext. Inno. Collaboration $\rightarrow$ DO & - & .05 & \\
\hline $\mathrm{H} 6 \mathrm{e}$ & Formalization of the Innovation Process $x$ Ext. Inno. Collaboration $\rightarrow$ DO & - & .08 & \\
\hline $\mathrm{H} 7$ & DO $\rightarrow$ Financial Innovation Returns & + & $.16^{* *}$ & $\checkmark$ \\
\hline $\mathrm{H} 8$ & DO $\rightarrow$ Innovation Process Effectiveness $\rightarrow$ Financial Innovation Returns & $+1+$ & $.29^{* *} / .08^{*}$ & $\checkmark$ \\
\hline H9 & DO $\rightarrow$ Innovation Process Efficiency $\rightarrow$ Financial Innovation Returns & $+1+$ & $.27^{\star \star} / .06^{\star}$ & $\checkmark$ \\
\hline $\mathrm{H} 10 \mathrm{a}$ & DO x Product Relatedness $\rightarrow$ Financial Innovation Returns & + & .02 & \\
\hline $\mathrm{H} 10 \mathrm{~b}$ & DO x Product Relatedness $\rightarrow$ Innovation Effectiveness & + & .03 & \\
\hline $\mathrm{H} 10 \mathrm{c}$ & DO $x$ Product Relatedness $\rightarrow$ Innovation Efficiency & + & $.08^{*}$ & $\checkmark$ \\
\hline $\mathrm{H} 11 \mathrm{a}$ & DO $x$ Innovation Radicalness $\rightarrow$ Financial Innovation Returns & + & .00 & \\
\hline $\mathrm{H} 11 \mathrm{~b}$ & DO x Innovation Radicalness $\rightarrow$ Innovation Effectiveness & - & $.12^{\star \star}$ & \\
\hline $\mathrm{H} 11 \mathrm{C}$ & DO x Innovation Radicalness $\rightarrow$ Innovation Efficiency & + & $.08^{*}$ & $\checkmark$ \\
\hline
\end{tabular}

${ }^{* *} p \leq .01 ;{ }^{*} p \leq .05$ (all effects one-sided); $\mathrm{DO}=$ design orientation; $\checkmark=$ hypothesis fails to be rejected

Investigating the interaction effects between the antecedents and the moderator external innovation collaboration reveals that for innovation strategy implementation and organizational innovation involvement, the moderator significantly influenced the antecedent's influence on design orientation. Thus, the results fail to reject H6b and H6c. The remaining interaction effects with external innovation collaboration were insignificant. Therefore, H6a, H6d and H6e are rejected. 
As predicted, the focal construct design orientation had a positive significant influence on financial innovation returns, in support of H7. Furthermore, the relationship was significantly, partially mediated by innovation process effectiveness and innovation process efficiency; thus, the results fail to reject $\mathrm{H} 8$ and $\mathrm{H} 9$.

Moreover, the results reveal that product relatedness does not significantly leverage the impact of design orientation on innovation process effectiveness and innovation process efficiency but does do so on financial innovation returns. Thus, H10a and H10b must be rejected, but H10c fails to be rejected. Finally, the results reveal that innovation radicalness has no significant influence on the relationship between design orientation and financial innovation returns, but does have a significant influence on innovation process efficiency. Therefore, H11a is rejected, but the results fail to reject H11c. Moreover, although innovation radicalness did leverage the impact of design orientation on innovation process effectiveness, it did so in the opposed direction hypothesized. Thus, $\mathrm{H} 11 \mathrm{~b}$ is rejected as well. Figure 3.2 summarizes the main effects.

Figure 3.2 Structural Model

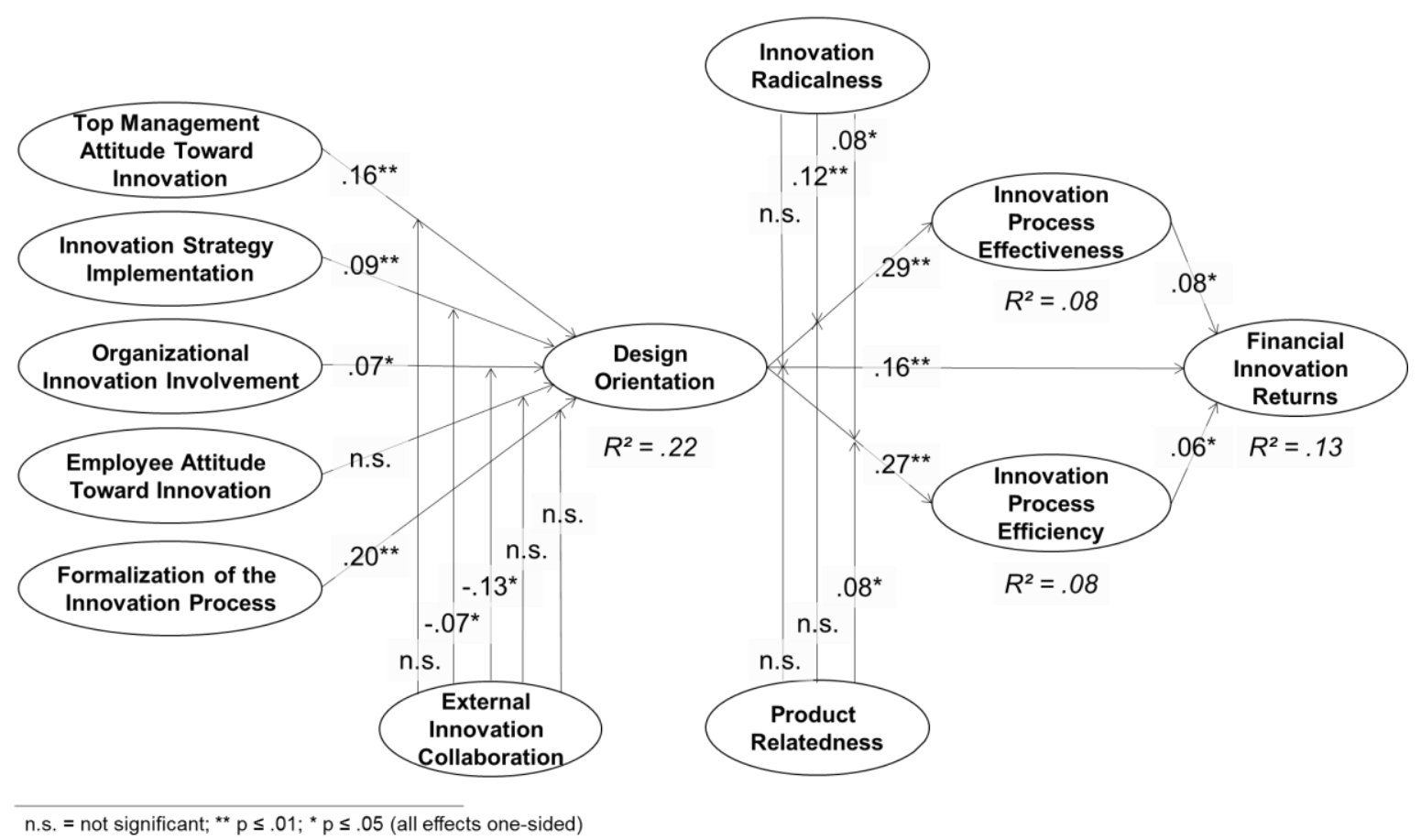




\section{Discussion and Conclusion}

Study 2 addresses the growing importance of design in the context of a firm's innovation management, which has received scarce attention from a conceptual and empirical point of view, so far (Verganti 2009). In particular, the study comprehensively identifies and tests antecedents and outcomes of design orientation on a firm level as well as the factors that influence the relationships among the constructs.

\section{Theoretical Implications}

\section{Antecedents of Design Orientation}

Whereas previous research on the antecedents of a design orientation is limited and fragmented (e.g., Beverland and Farrelly, 2007; Calabretta et al., 2008), study 2 integrates and empirically validates a set of antecedents. In particular, we find that a positive top management attitude toward innovation, a profound innovation strategy implementation, organizational innovation involvement and formalization of the innovation process facilitate a design orientation.

With regard to the first two antecedents, the results of this study are in line with the common assumption that strategic and managerial support is necessary for a design orientation (Borja de Mozota, 2003). More specifically, the study demonstrates the link between managing innovation and design by showing the need of a general strategic focus on innovation to support the implementation of design orientation. Unexpectedly, however, employee attitude toward innovation does not foster design orientation. This finding might imply that such an attitude is not sufficient to drive design orientation, but rather that employees explicitly need to have a positive attitude toward the set of principles and tools that encompass a design orientation. Comparing the antecedents of design orientation, it is surprising that formalization of the innovation process turned out to be its strongest driver, given that some 
research indicates that formalization actually decreases a firm's overall innovativeness (e.g., Walker and Ruekert, 1987). In essence, the findings show that the advantages of formal guidelines for implementing design principles seem to outweigh its potential risks (see Walker and Ruekert, 1987 for related discussion). Notably, the strength of that driver may partially be attributed to the large number of SMEs in the sample. Because small companies typically show low levels of formalization (Pelham and Wilson, 1996), formal guidelines that enable design principles to be implemented might be especially instrumental for small companies with rather unstructured innovation processes.

Furthermore, the findings demonstrate that the impact of top management attitude toward innovation and formalization of the innovation process on design orientation were not affected by the degree of companies' external innovation collaboration. However, we found that external innovation collaboration moderates the influence of innovation strategy and organizational innovation involvement on design orientation. Those findings enrich Filippetti's (2011, p. 20) study on innovation modes, which states that "design considerably benefits from collaboration and an interactive attitude with the social environment." Indeed, the findings of study 2 do not contradict Filippetti (2011) but rather suggest that although design orientation in itself involves intensive interaction with external sources, higher degrees of firms' collaboration diminish the value of design processes as information hubs. In turn, external collaboration deflects from a design orientation. Thus, the present study points to a rivalry between open innovation and design orientation approaches.

\section{Outcomes of Design Orientation}

Previous studies quantifying design's contribution to financial performance predominantly focus on the direct effect (e.g., Candi and Saemundsson, 2011; Gemser and Leenders, 2001; Swan et al., 2005) and trace back the influence to design's added value to innovation outputs, 
which is in line with our argumentation and findings. Study 2 extends these findings, showing that design orientation also leads to an improved commercialization of ideas and a greater share of project targets met, which in turn further improves financial innovation returns. In doing so, these findings also add to the emerging design thinking literature (e.g., Brown, 2009; Martin, 2009), in that they demonstrate design's role beyond its direct effect on final innovation output.

In contrast to the expectations, the direct influence of design orientation on financial innovation performance did not change according to the innovation radicalness or product relatedness. This finding suggests that design orientation equally adds value to product and non-product as well as radical and incremental innovations, which supports the growing adoption of design in various business areas (Brown, 2008; Martin, 2011). However, the impact of design orientation on innovation process efficiency and effectiveness is not unconditional. As expected, the results show that design is a more effective trigger for meeting time-, cost-, quality-, and launch-related targets in the context of radical rather than incremental innovations and product rather than non-product innovation outputs. Those findings support the argument that design processes and tools are more useful in the context of their origin discipline and in situations of greater uncertainty that may accompany more radical innovations. Turning around the latter argumentation, our findings also imply that design orientation can be a useful strategy to deal with radical innovation. With respect to product relatedness, design tools that support the predictability of market acceptance and help anticipate problems during production seem to work better for product- rather than nonproduct-related innovation projects, as expected. However, contrary to our expectations, the impact of design orientation on the effectiveness of the innovation process does not differ for product versus non-product innovation outputs. Those results provide support for the growing perception of design as a trigger for all innovation outputs (e.g. Brown, 2009; Martin, 2009). 
In addition, we found the expected moderation by innovation radicalness to be in the opposite direction, which contrasts the argumentation offered by Verganti (2009). In fact, companies with a focus on radical innovation projects profit significantly more from a design orientation in terms of commercializing new concepts than companies that predominantly focus on incremental innovations. Notably, Verganti (2009) argues that to develop radical innovations, companies need a network of interpreters and points out that designers are advanced interpreters. Adding to this, our findings suggest that the interpretation role of design principles holds more weight than a potential fixation on existing solutions, which Verganti (2009) assumes hinders the development of more radical approaches.

\section{Managerial and Policy Implications}

The aforementioned findings lead to several implications for managers across industries. First, managers interested in improving innovation process effectiveness, innovation process efficiency, and financial innovation returns should consider implementing design processes, principles and tools throughout the organization. In particular, managers who lead companies focusing on product rather than non-product innovations and radical rather than incremental innovation should pay attention to such a firm-wide design orientation, as these companies benefit from its implementation the most. The innovation-related firm factors identified and tested here can serve as a framework to guide transformational initiatives that pave the way for such an orientation and the use of design as a strategic tool to foster innovations.

Building on this framework, managers themselves might consider innovation-related personal coachings, that can help them deal with novelty, change, and uncertainty, if they are not open to new ideas in general. Moreover, managers could implement an innovation strategy by enhancing firms' internal communication about its objectives. Focusing on the organization, managers should strengthen the collaboration across departments, which could be achieved by 
team events or interdisciplinary innovation workshops (Martin, 2011). On the operational level, managers should implement a formal innovation process by defining rules that manifest the role of innovation actors and approaches to enable design principles and tools to be applied.

If a firm collaborates to a great extent with external actors during the innovation process, managers should ensure that the design orientation is not suppressed by an open innovation approach. To avoid such rivalry, managers of collaborating firms could explicitly anchor design processes within the innovation strategy and highlight the value of design principles and tools through the firm's internal presentations mentioned previously. Moreover, interdisciplinary workshops could center on design tools to point out how they can be used to improve the firms' interfaces with external actors. In doing so, design orientation and open innovation might even benefit from a parallel integration rather than suppress each other.

Finally, our overall findings underscore the meaningfulness of political support for design implementation, as it has been demonstrated to drive innovation performance throughout industries. Therefore, policy makers should further support innovation benchmarking tools that highlight firm factors, which companies should enhance to foster design orientation. Moreover, policy makers could develop programs that support the establishment of innovation firm factors that pave the way for a design orientation. These programs could be facilitated by funding schemes that provide financial support for companies that engage a trained management consultant. The UK government successfully used a comparable approach two decades ago for new product development projects (Potter et al., 1991).

\section{Limitations and Suggestions for Further Research}

As with all research, this study is not without limitations, which could be addressed by further research. First, study 2 considers only employee attitude toward innovation, derived from the 
building blocks of corporate culture (Clemente and Greenspan, 1999), as a driver of design orientation. Although several authors highlight the importance of culture for developing a design orientation, the results of this study do not support this hypothesis. Therefore, further research might consider other cultural elements to provide a more fine-grained picture of corporate culture's potential impact on design orientation (Beverland and Farrelly, 2007; Calabretta et al., 2008).

Second, the present study was limited by the use of one data set, which comprised solely firmrelated information. Thus, further research might consider additional data from external actors to measure design orientation's impact on the market. Researchers could use customer satisfaction scores, for example, to validate the proposed potential of design to identify and transform customer needs (cf. Veryzer and Borja de Mozota, 2005).

Third, study 2 assesses the degree of design orientation but sheds only limited light on its qualitative and experiential aspects. Previous research (e.g., Borja de Mozota 2002) shows that companies' design experience significantly increases the likelihood of design being a company's core competency; thus, further research could examine whether such aspects influence the relationships between design orientation and innovation outcomes. 
Appendix - Measures and Items

\begin{tabular}{lc}
\hline Constructs & Loading \\
\hline Top Management Attitude to Innovation & \\
(Seven-point scale: $1=$ "not applicable"; $7=$ "fully applicable") & \\
How would you rate top management attitude to innovation? & .85 \\
Excited/passionate about innovation & .81 \\
Open rather than sceptical towards new unusual ideas & .87 \\
Able to think out of the box & .86 \\
Imaginative & .79 \\
Able to "sell" ideas internally & .67 \\
Focusing on business impact &
\end{tabular}

Innovation Strategy Implementation

(Binary scale: $0=$ "not applicable"; 1 = "applicable")

Does your company have an innovation strategy? If yes, which of the following attributes apply?

It sets clear objectives for your innovation management activities

It sets the objectives for your project management in each innovation project $\quad .72$

It provides the basis for organizational changes and business model

development

\section{Organizational Innovation Involvement}

(Seven-point scale: 1 = "not at all"; $7=$ "highly regularly")

How regularly do you involve the following groups to generate new ideas and to collect suggestions for improvement?

Purchasing

Marketing \& sales

Production / service development

\section{Employee Attitude to Innovation}

(Seven-point scale: 1= "not applicable"; 7= "fully applicable")

How would you rate employee attitude to innovation?

Excited/passionate about innovation

Open rather than sceptical towards new unusual ideas $\quad .82$

Able to think out of the box $\quad .83$

Imaginative $\quad .85$

Able to "sell" ideas internally $\quad .88$

Focusing on business impact $\quad .76$

\section{Formalization of the Innovation Process}

(Seven-point scale: $1=$ "not at all"; $7=$ "successfully in place")

To what degree do you have a formal process (with clearly defined stages,

milestones etc.) in place for product, service, process, organizational or business model development?

Product innovation

Service innovation $\quad .74$

Process innovation $\quad .87$

Organizational innovation $\quad .86$

Business model innovation $\quad .85$ 


\begin{tabular}{lc}
\hline Constructs (cont.) & Load \\
\hline Design Orientation & \\
(Seven-point scale: 1 = "not at all"; 7 = "to a very high extent") & \\
Over the last 3 years, to what extent has design contributed to your Innovation & \\
Management in the following way? & .88 \\
Design was an integral part of our innovation strategy & .91 \\
Design thinking was a driver of our innovation culture & .89 \\
Design played an important role in our idea generation & .89 \\
Design played an important role during the development phase & .89 \\
Design was essential when launching innovations & .89 \\
Design contributed to our continuous improvement & .76 \\
Design was important in our recruiting and HR development &
\end{tabular}

\section{Innovation Process Effectiveness}

(Seven-point scale: $1=$ "not at all"; $7=$ "to a high extent")

To what extent do you commercialize internally developed ideas, concepts and market-ready products (licensing or selling it to external partners, customers, etc.)?

Selling of internally developed ideas or concepts

\section{Innovation Process Efficiency}

(Percentages)

For innovation projects in the last three years (for which targets were defined), what percentage met targets with respect to time, budget and quality?

Percentage of projects where time targets were met (in \%)

Percentage of projects where budget targets were met (in \%)

Percentage of projects where quality targets were met (in \%)

What percentage of your projects launched during the last 3 years (for which launch-specific targets such as "number of sales within a specific time frame," "turnover from these sales," "timing of first sales," etc. are defined) met launch specific targets?

Percentage of projects launched where launch-specific targets were met (in $\%)$

\section{Financial Innovation Returns}

(Percentages)

Average share of EBIT from innovation (estimated by respondents) during the previous three years

Average share of income from innovation (calculated) during the previous three years

\section{External Innovation Collaboration}

(Seven-point scale: $1=$ "not at all,"; 7 = "to a very high degree")

How much do informal relationships with external sources without any formal agreement (e.g. without confidentiality agreements etc.) enhance each phase of the entire innovation life cycle?

Idea management

Product/service/process/organizational or business model development 


\section{Single Item Measures}

\section{Product Relatedness}

(Binary coded)

1 More product innovation projects started in company

0 More other innovation projects started in company

\section{Innovation Radicalness}

(Binary coded)

1 More radical ideas generated in company

0 More incremental ideas generated in company

\section{Region (per Continent)}

(Binary coded)

1 Company based in respective region

0 Other

\section{Type of Industry (per Industry)}

(Binary coded)

1 Company belongs to respective industry

0 Other

\section{Company Age}

(Integer number [years])

\section{Number of Employees}

(Integer number)

\section{Innovation Spending}

(Integer number [euros])

\section{Recency of Measurement}

(Binary coded)

1 Questionnaire filled out during second half

0 Questionnaire filled out during first half

\section{Type of Assessment}

(Binary coded)

1 Guided assessment by consultant

0 Nonguided assessment 
CHAPTER 4. DESIGN THINKING DURING THE FUZZY FRONT END:

AN EXPLORATION OF THE IMPACT OF DESIGN THINKING ON TEAMWORK AND IDEA QUALITY

A manuscript based on this chapter has been submitted for publication in the Journal of Services Marketing, with the following bibliographic reference: Dülfer, N., Mahr, D., Gericke, M., and Wetzels, M. (2014). Design thinking during the fuzzy front end: An exploration of the impact of design thinking on teamwork and idea quality. 


\section{Introduction}

Proper management of the innovation process is crucial for the long-term agility of companies (Antioco et al., 2008). Upfront activities in particular are positively related to innovation success (Cooper and Kleinschmidt, 1993). Thus, special attention should be paid to this "fuzzy" phase, in which needs are identified and ideas generated and assessed (Schirr, 2012). Yet, a recent study conducted by Accenture revealed that only a third (38\%) of the companies surveyed are satisfied with their ideation and idea management performance (Koetzier and Alon, 2013).

In an attempt to enhance innovation teamwork and in turn, innovation success, organizations such as the software company Intuit or the pharmaceutical company Pfizer have started to adopt design thinking as a front end process encompassing observation, brainstorming and idea prototyping steps (Liedtka, 2011; Martin, 2011). This development has been complemented by an emerging stream of research on the design thinking process (e.g. Clark and Smith, 2008; Junginger, 2007) and a number of case studies highlighting its success across settings such as a public library (Bell, 2008), a non-profit organization (Brown and Wyatt, 2010), and a high tech company (Holloway, 2009). Although studies in that stream provide interesting insights into elements and applications of design thinking, they are inconsistent in their interpretation of the process (Johansson-Sköldberg et al., 2013). Moreover, the case studies lack empirical evidence of the impact of design thinking on innovation activities and outcomes (Johansson-Sköldberg et al., 2013). Yet, these insights would be necessary to justify the growing attention of design thinking in businesses, education and academia and to provide managers and researchers with a better understanding of the benefits and limitations of this process (Ungaretti et al., 2009). 
While Wattanasupachoke (2012) made a first empirical attempt and demonstrated that design thinking significantly enhances a company's innovativeness, there is a lack of empirical studies that address design thinking on a project level. Such a perspective would enable the examination of design thinking's influence on teamwork because innovation efforts are typically performed in project teams (Mahr et al., 2014). Focusing on an entire firm that might run various structured and unstructured innovation approaches simultaneously might disguise such insights. As a notable exception, Seidel and Fixson (2013) took a team perspective to find that high performing teams of students made greater use of the design thinking steps during concept generation than low performing teams. Yet, the authors already acknowledge that the cause-and-effect relationships remain unclear and require further investigation (Seidel and Fixson, 2013).

Extant case studies on the impact of design thinking to date have largely omitted the definition of design thinking as a clearly distinct team process that can be compared to the unstructured front end process of innovating teams. These studies also provide only limited insights on how teams react to the application of the design thinking process and how its application influences the quality of teams' ideas. However, such investigations are needed to reveal more detailed insights of the role of design thinking as a front end process.

Following recent calls for research on design thinking in the context of innovation and teams (e.g. Di Benedetto, 2012; Johansson-Sköldberg et al., 2013; Marketing Science Institute, 2014), study 3 seeks to provide answers to the following research question:

- What is the impact of the design thinking process on teamwork and on idea quality during innovations' fuzzy front end?

Study 3 follows an explorative approach to make three key contributions to the emerging discourse on design thinking. First, the study enriches design thinking literature by 
conceptualizing and specifying design thinking as a front end process. To our knowledge, this study is the first to experimentally explore its effects in comparison to the unstructured fuzzy front end process. Conducting the research in this context enriches current literature such as the work of Seidel and Fixson (2013) who already mentioned that "[i]f design thinking is to be widely adopted, less-experienced users will employ these methods together, but we know little about their effect when newly adopted" (p. 19).

Second, study 3 provides a more fine-grained picture of the impact of design thinking by exploring its impact through an innovation team lens. In particular, the suggested conceptual model relates design thinking to several processual teamwork characteristics and idea quality dimensions. Such model pays tribute to the growing interest in design thinking among practitioners and scholars as it shows that design thinking drives team interrelationships that enhance the quality of the generated ideas.

Third, this study contributes to the status quo in design thinking research, as it provides initial empirical support for the proposed conceptual model, based on data gathered in a laboratory experiment. In doing so, it provides evidence of the usefulness of the design thinking process, which has often been discussed only on a conceptual or case study level (JohanssonSköldberg et al., 2013; Ungaretti et al., 2009).

Chapter 4 is structured as follows. The following section conceptualizes design thinking and describes its phases in detail, namely observation, brainstorming and idea prototyping \& testing. Subsequently, the literature on design thinking is discussed against the backdrop of established factors of teamwork and idea quality. Afterwards, the methodology of the experimental design is outlined, and the empirical analyses and results are presented. The chapter concludes with a discussion on the assessed influences of design thinking and finally points out limitations while making suggestions for further research. 


\section{Conceptualizing Design Thinking as an Iterative Front End Process}

Although the term design thinking has been inflationary used in recent years, the broader discourse on the topic spans four decades of research (Johansson-Sköldberg et al., 2013). In this study, we focus on the more recent interpretation of design thinking as a process in which design tools are applied by designers and non-designers in various innovation contexts (Brown, 2009; Lockwood, 2010). Such process has increasingly been adopted by companies across industries (Martin, 2011; Wattanasupachoke, 2012). In particular, companies adopt design thinking early on in the innovation process to identify opportunities, generate ideas and refine and select concepts, which constitute key components of the front end of innovation (Koen et al., 2001). Notably, innovation's front end activities are particularly important, because essential aspects of the final innovation are defined early on (Reid and de Brentani, 2004) and because their execution determines new product success (Cooper and Kleinschmidt, 1993). Yet, it is often the least structured and most difficult part to manage (Khurana and Rosenthal, 1997). Therefore, the design thinking process seems to be a suitable solution, because it provides a basic structure for the front end process, without formalizing it too strictly, which may jeopardize innovative ideas (Walker and Ruekert, 1987).

The notion of design thinking as a process can be traced back to the US-based design consultancy IDEO (Johansson-Sköldberg et al., 2013), whose representatives used the term as the company increasingly took over design tasks besides traditional product design (Brown and Wyatt, 2010). Although the developed innovations differ in terms of tangibility, the company uses the same iterative process for all of its projects, encompassing overlapping and repeating phases of inspiration, ideation and implementation (Brown, 2008).

In line with IDEO's engagements, researchers have published articles on applications of the design thinking process within different industries ranging from information technology 
(Clark and Smith, 2008; Martin, 2011) to pharmacy (Liedtka, 2011). Although the terminologies of the steps within the process differ, three basic elements were identified that most applications share, namely observation, brainstorming and idea prototyping \& testing (see Seidel and Fixson, 2013 for related discussion).

\section{Observation}

The design thinking process starts with a review of existing situations and solutions; it includes identifying met and unmet "stakeholder needs - the needs of customers, users, value chain partners, as well as internal corporate requirements" (Beckman and Barry, 2008, p. 82). Observation in the sense of design thinking is often described as an ethnographic research methodology (e.g. Beckman and Barry, 2007; Kimbell, 2011), which is operationalized via watching videos of users, observing others in real life or by performing actual user tasks (Brown, 2009; Fulton Suri, 2000).

Using observation techniques in order to innovate is a relatively new concept. The observer seeks to understand, for instance, the behavior of users and identify the triggers that cause them to act as they do (Beckman and Barry, 2007). In doing so, this approach yields insights that might be unconscious to the observed person or difficult to express, which can help to uncover people's latent needs (Brown and Wyatt, 2010). Therefore, observation has the potential to identify needs and business opportunities that might be overseen using more traditional research methods such as focus groups, interviews or market reports (Beckman and Barry, 2007).

\section{Brainstorming}

The second element of the design thinking process is brainstorming. During such sessions, ideas are generated and shared in face to face groups, whereby interdisciplinarity is appreciated (Brown and Wyatt, 2010). IDEO reserves its own private rooms for its 
brainstorming sessions, in which four simple rules are written on the wall in order to ensure productivity: "efer judgment", "encourage wild ideas", "stay focused on the topic" and "build on the ideas of others" (Brown, 2009, p. 78). Those brainstorming rules are comparable with the ones defined by Alex Osborn (1957) who has popularized this idea generation method. Notably, Osborn's rules have been found to significantly increase brainstorming effectiveness in groups (Litchfield, 2008).

Next to the rules, IDEO uses Post-it notes as an instrument to capture and sort ideas during brainstorming sessions (Brown, 2009). This omnipresent office equipment has become a prominent tool of the design thinking process. In essence, Post-it notes are ideally suited to capture a variety of ideas that single team members develop, post them on walls and then group them according to certain aspects or bring them into a logical order. Doing so shall spur both divergent thinking in order to create choices and convergent thinking in order to make choices (Brown, 2009).

Prior studies pointing out the ineffectiveness of brainstorming in groups have focused on the quantity rather than the quality of ideation outputs and predominantly neglect other benefits apart from ideation outcomes (Schirr, 2012). In fact, brainstorming integrates all innovation team members in decision-making processes and therefore enables them to evaluate ideas from different angles (Martin, 2011). In a similar vein, Sutton and Hargadon (1996) identified that companies may benefit from brainstorming in terms of providing "kill variety" among group members. Moreover, the intensive interaction among team members has been shown to have an impact on the social fabrics of groups (Seidel and Fixson, 2013). In sum, these findings point to a set of brainstorming benefits besides the amount of ideation outputs. 


\section{Idea Prototyping \& Testing}

Building prototypes of ideas and testing them comprises the third step of the design thinking process. A prototype in the sense of design thinking does not have to be complex (Brown, 2008). In essence, it is about giving form to an idea in order to receive feedback concerning its strengths and weaknesses and refine the prototype accordingly (Gattiker, 2012). In design thinking processes, a prototype "is typically a drawing, model, or film that describes a product, service, or system" (Brown, 2005, p. 53). More intangible innovation outcomes such as processes, systems and services, are furthermore prototyped based on scenario building techniques using mediums such as storyboards, flow charts or role plays (Fulton Suri and Marsh, 2000; Gattiker, 2012). Those approaches allow innovating groups to better understand possible sequences of events such as during check-in processes at hotels or software uses (Brown, 2009).

\section{Iteration of the Phases}

Design thinking is an iterative process with overlapping rather than completely separate steps. Using these phases in parallel and in loops shall enhance the advantages of the process. Prototyping, for instance, may also be used during brainstorming sessions in order to better express one's thoughts to other group members (Grosskopf et al., 2010) and observing team members, while using these prototypes may yield new insights that can be shared in another brainstorming session (Simons et al, 2011). In turn, the ideas can be refined and again visualized using new idea prototypes, which are tested and observed while being used, refined and so forth. These iterations may prevent teams from accepting or skipping ideas too early, whereby the latter one has been identified as one of the key failures during the fuzzy front end (Khurana and Rosenthal, 1997). In contrast, the iterations of the design thinking process 
encourage teams to build upon, review and adopt ideas, so that the valuable aspects of an idea are identified, combined and put forward until a satisfying solution is found.

\section{Relationships between Design Thinking, Teamwork and Idea Quality}

\section{Conceptual Model}

The emerging literature on design thinking as an innovation front end process suggests that its application increases organizational innovativeness in terms of the number of new business ideas generated (Martin, 2011) and the success of newly launched products (Liedtka, 2011), services (Hempel, 2007) or processes (Brown, 2008; Brown and Wyatt, 2010). However, current research is often phenomologically grounded rather than drawing on theoretically grounded frameworks to explain how design thinking influences teamwork during the front end processes and the quality of the innovation outcomes respectively (Johansson-Sköldberg et al., 2013). Nevertheless, such an established framework makes it easier to compare design thinking to unstructured fuzzy front end processes as examined in prior literature. Therefore, the present study draws on processual teamwork characteristics and innovation performance criteria derived from a meta-analysis of innovation team performance by Sivasubramaniam et al. (2012). Their conceptual model captures a comprehensive set of team process variables that are linked to performance outcomes, which meets this study's objectives.

Four process variables were identified that describe how teams interact and accomplish tasks, namely internal communication, external communication, group cohesiveness and goal clarity (Sivasubramaniam et al., 2012). For our context, we adapt 'external communication' to "exploitation of external sources" for the following reasons. First, external participants are often included within the design thinking process (Brown, 2009), which makes it difficult to distinguish between external and internal communication in this context. Second, when it comes to the impact on performance, it is particular important that innovating teams process, 
evaluate and apply external information rather than just exchanging it (Sivasubramaniam et al., 2012).

Furthermore, we use "shared solution understanding" instead of "goal clarity". In design thinking processes, goals often change over time and are not interpreted as static concepts (Brown, 2008), but solutions need to be understood by the team members at all times.

Concerning the performance outcomes, we focus on innovation output effectiveness rather than efficiency, because the objective of the this study was to shed more light on the broad spectrum of idea quality criteria. The quality of a creative outcome is predominantly assessed by its novelty (Dean et al., 2006; Kristensson et al., 2004) but - according to a meta-analysis

- also by its relevance, feasibility and specificity (Dean et al., 2006). We adopted this holistic perspective accordingly. Figure 4.1 visualizes the resulting preliminary conceptual model.

\section{Figure 4.1 Impact of Design Thinking}

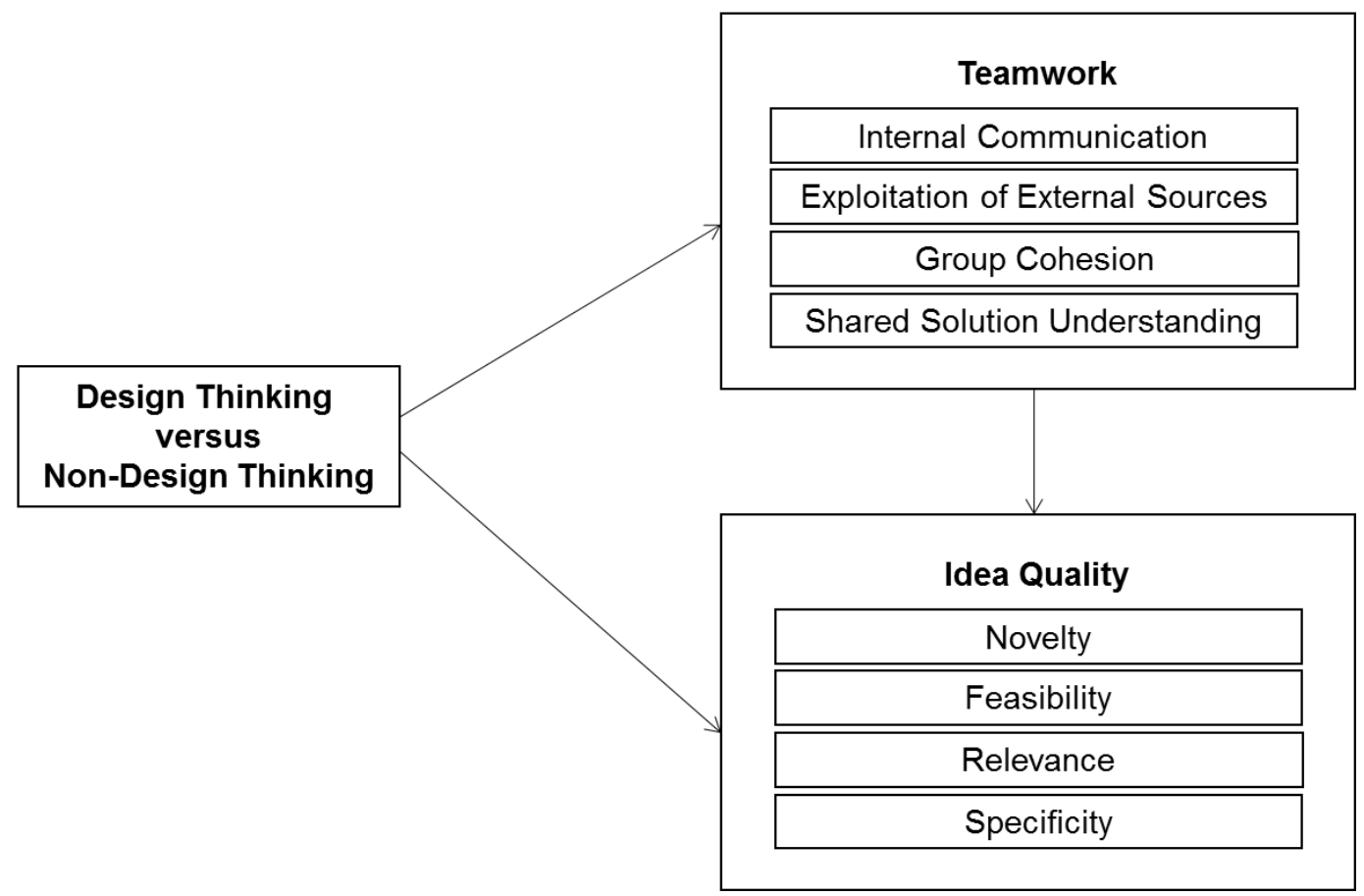

In the following sections, we examine the relationships mentioned in the model above. 


\section{Impact of Design Thinking on Front End Team Work}

\section{Impact on Internal Communication}

In this study, internal communication is defined as "the frequency and openness of information exchange among team members" (Sivasubramaniam et al., 2012, p. 806). The design thinking process may encourage internal communication in multiple ways. Brainstorming sessions bring people together, rather than having them separated or exchanging ideas only via presentations (Martin, 2011). In contrast to regular meetings, brainstorming sessions in design thinking processes are active and engaging events (Kelley, 2001). In an early study of brainstorming groups at IDEO, one designer stated that "we talk to people a lot; we allow our assumptions to be challenged or even deflated" (Sutton and Hargadon, 1996, p. 696). Brainstorming rules that prevent criticism and encourage uncommon ideas may enhance communication even further, as this conceivably reduces team members' fear of being judged (Kelley, 2001).

Moreover, the literature on design thinking suggests that prototyping increases internal communication among team members (e.g. Brown, 2005; Leonard and Rayport, 1997; Junginger, 2007). In line, Brown (2005) notes that the goal of prototypes is to "elicit feedback" and Leonard and Rayport (1997) point out that physical representations of new concepts "stimulate communication". Especially in interdisciplinary teams, or in situations when team members have different levels of expertise, prototypes can span language boundaries and remove barriers to participation (Grosskopf et al., 2010). Thus, we expect that design thinking will have a positive influence on internal communication. 


\section{Impact on Exploitation of External Sources}

Building on the definition of external communication by Sivasubramaniam et al. (2012) we refer to exploitation of external sources as the degree to which information sources from inand outside the organization are gathered and processed.

The literature on design thinking indicates that the process may increase the exploitation of external sources by targeting not only the conscious and articulated, but also the unconscious and unspoken needs (Brown and Wyatt, 2010). Notably, customers can often not imagine or express preferred solutions (Mahr et al., 2014). Based upon this, Beckman and Barry (2007) point out that "observation yields insights that focus groups, interviews and other such methods cannot” (p. 32). In support for this proposition, Leonard and Rayport (1997) describe a case in which observations of computer program users uncovered a functional problem that the user did not mention when being asked about it because she had become so accustomed to it.

Besides identifying more needs, the design thinking discourse suggests that the process also leads to a greater use of the information received. For instance, Brown (2008) describes how a design thinking project team that is aiming to develop a new bicycle for baby boomers and therefore spent time with them, identified customers' dissatisfaction with the bike retail experience. In turn, the team developed entirely new in-store retailing strategies next to the planned new bike concept (Brown, 2008), which demonstrates the holistic perspective that teams take when applying the design thinking process. In sum, we expect that the application of the design thinking process will increase the exploitation of external sources.

\section{Impact on Group Cohesion}

In line with Sivasubramaniam et al. (2012) we define group cohesion as "the extent to which group members feel a strong personal bond with each other” (p. 806). 
Design thinking may increase group cohesion due to the high degree of interdependence between team members along the process steps. As described in the literature, the design thinking process encourages people to build on other team members' ideas rather than criticizing them for their proposed concepts (e.g. Brown, 2009; Kumar, 2009). Proceeding in such a way is likely to spur team members positive affective responses and in turn the perceived closeness among them. Moreover, teams applying design thinking reflect on each other's prototypes (Simons et al., 2011; Gattiker, 2012), which may also lead to a better integration of team members and therefore strengthen the social relationships between them. In line, Seidel and Fixson (2013) argue that brainstorming appears to have a positive effect on the integration and socialization of new team members and Sutton and Hargadon (1996) conclude that brainstorming is particularly relevant, as "these meetings help set, reinforce, and reflect organization-wide values and norms" (p. 702). Further supporting a positive impact on group cohesion, Ward et al. (2009) demonstrate that companies which participated in a program to implement design thinking within their organization showed higher degrees of interdepartmental work. Against the backdrop of these findings, we expect that teams using design thinking will experience greater bonds among group members.

\section{Impact on Shared Solution Understanding}

We refer to shared solution understanding as the degree to which team members share an understanding of the proposed solutions (Hirst and Mann, 2004). The design thinking process is seen to add to such a shared understanding by visualizing and discussing concepts using sketches, post-its or other rudimentary prototypes early on (Brown and Wyatt, 2010). Brown (2008) exemplifies the potential of visualizing ideas when he describes how the prototype of a medical instrument, made out of a whiteboard marker, a film canister and a clothespin, helped non-medics within a project team better understand the ideal properties of the solution, which was thought of by a doctor. In essence, all team members were able to imagine the desired 
functions and could develop a shared understanding of the proposed solution. In summary, we expect design thinking to positively influence shared solution understanding among team members.

\section{Impact of Design Thinking on Idea Quality}

\section{Impact on Idea Novelty}

We define idea novelty as the degree to what the idea is original (adapted from Dean et al., 2006), whereby higher degrees of originality refer to more radical rather than incremental concepts (Magnusson, 2009).

Beckman and Barry (2007) argue that the design thinking process, and in particular the ethnographic methodologies used, help to understand why people do things and to identify the underlying needs an existing solution should satisfy (Beckman and Barry, 2007). Such understanding of needs (e.g., to transport things) and not only of the existing solutions (e.g., a car), enables teams to see a problem in a broader context (Leonard and Rayport, 1997). In line, Leonard and Rayport (1997) exemplify how managers of computer companies who applied design methods started to think about new communication solutions instead of enhanced laptop qualities. Thus, rather than optimizing existing solutions, the design thinking process may encourage teams to think about entirely new solutions that address the needs (Beckman and Barry, 2007; Verganti, 2009). Given this, the design thinking process is likely to spur novel ideas.

The empirical results of Wattanasupachoke (2012) indicate that the use of design thinking does indeed increase companies' level of innovativeness. Thus, we expect that design thinking will have a positive influence on the novelty of single ideas. 


\section{Impact on Idea Feasibility}

We define idea feasibility as the degree to which the idea can be easily implemented (adapted from Dean et al., 2006).

The design thinking discourse suggests that this process leads to more feasible ideas, because its phases encourage team members to constantly reflect on the constraints of a project, not only in terms of what is desirable from a customer perspective, but also in terms of what is economically viable and functionally feasible (Brown, 2009). Observation of the current usage situation may already point to some basic functional constraints that the solutions needs to address and that cannot or shall not be eliminated. Applying observation techniques in a project to improve patient care in a hospital may, for instance, reveal that doctors cannot give certain patients a handshake for hygiene reasons. Identifying such constraints is likely to keep innovating teams from developing solutions that would offend the target group, and in turn support the development of more feasible solutions (Brown and Wyatt, 2010). Brainstorming is likely to further enhance the knowledge of constrains in a team, given that members with different personal and educational backgrounds review problems and solutions from different angles. For instance, a technician may point to the constraints of a material that a business person suggests due to its low price. Finally, building and testing prototypes enable team members to simulate solutions, to detect infeasible or unviable solutions early on.

The findings of Ungaretti et al. (2009) provide some support for the assumption that design thinking is likely to yield more feasible solutions. The authors ascertained that crossdisciplinary teams of business and design students who applied design approaches, developed new business models for an international corporation that were rated as "insightful, creative and feasible" by the company's managers (Ungaretti et al., 2009, p. 8). Although cause-andeffect relationships were not assessed by the authors, the results hint that design thinking 
yields feasible outcomes. Thus, we expect that design thinking will have a positive influence on idea feasibility.

\section{Impact on Idea Relevance}

We define idea relevance as the degree to which the idea applies to a certain problem (adapted from Dean et al., 2006). Given that the design thinking process centers on needs (rather than e.g. technologies, or materials) and tests solutions early on, it is likely that the process yields particular relevant ideas.

In support of this, Martin (2009) describes how one of the oldest "wicked problems" - what people need to enable them to sit down to work - was tackled by observing people in order to gain a deep understanding of their needs. In particular, the design team of the Aeron office chair observed that people were shifting their position on common, upholstered office chairs, because they were seeking a cooler position. In turn, the Aeron chair was equipped with a mesh instead of upholstery and became the most successful office chair in history (Martin, 2009).

Idea prototyping might further assure idea's relevance, as suggested solutions can be tested early on. Doing so is likely to yield insights on the relevance of certain features that might otherwise remain uncovered. In line, Brown (2009) points out that "[t]he purpose of early prototypes might be to understand whether an idea has functional value" (p. 91). Given these insights, we expect that design thinking will increase idea relevance.

\section{Impact on Idea Specificity}

We define idea specificity as the degree to which the implication of an idea is clearly worked out rather than vague (adapted from Dean et al., 2006). 
The design thinking process is likely to enhance idea specificity, as the implications of an idea are constantly assessed and reviewed during the process. In contrast to innovation approaches based solely on market research data, design thinking encourages teams to test ideas in real settings (Brown and Wyatt, 2010). Doing so yields insights on cause-and-effect relationships that may not be captured in secondary research sources such as market reports or conceptual studies. In support for such proposition, Brown and Wyatt (2010) describe how a design thinking team, which was aiming to develop a new eye screening process for children in India, flew to the country in order to observe the existing eye screening process that preceded each eyeglass prescription (Brown and Wyatt, 2010). Doing so revealed that children were afraid of the eye screening process itself, which kept them from receiving glasses (Brown and Wyatt, 2010). Based on this observation, the team was able to refine the process by prototyping it, until the children's reactions to the process were positive and the solution exactly matched their needs (Brown and Wyatt, 2010). Notably, the implications of a concept can also be tested within the team, e.g. via role play or storyboards (cf. Fulton Suri and Marsh, 2000; Gattiker, 2012). Both approaches are likely to enable teams to realize real cause-and-effect relationships, so that the implications of developed ideas become apparent and can be considered in the final solution (Brown, 2009). Hence, we expect that design thinking will have a positive impact on idea specificity.

\section{The Relationship between Teamwork and Idea Quality}

While design thinking discourse is scarce on the relationship between front end teamwork and idea quality, it is widely established within innovation literature (e.g. Hülsheger et al., 2009; Sivasubramaniam et al., 2012). The meta-analyses of Hülsheger et al. (2009) and Sivasubramaniam et al. (2012) confirmed a positive impact of the team process variables on innovation outcomes (for a detailed argumentation see above mentioned meta-analyses). 
Thus, the focus of our empirical validation lies on the impact of design thinking on teamwork and idea quality, respectively.

\section{Methodology}

We gathered data through a 'realistic laboratory experiment' to explore the impact of design thinking on front end teamwork and idea quality. Given the explorative nature of this study, and the practice-based context of the design thinking discourse, we chose such intermediate approach, that sorts between "real world design" and "lab experiments" in a highly controlled environment, using simple tasks, and focusing solely on cognitive processes (for related discussion, see Hernandez et al., 2010). Doing so enabled us to control for several extraneous influences and assess cause-and-effect relationships, while at the same time allowed for the use of realistic design thinking processes and tasks.

\section{Participants}

30 advanced students (11 males and 19 females; mean age $=24.3$ years) from a European university were asked to participate in the experimental study. Participants were informed that the experiment lasts a maximum 3 hours, and received a $15 €$ voucher for their participation, redeemable in a number of local stores. All participants were randomly assigned to 5-person groups that were equally heterogeneous with regard to age, gender and education program, which yielded 6 groups in total. Groups were randomly assigned to one of two conditions.

\section{Conditions}

Participants in the design thinking condition were exposed to a presentation on the process and took part in a workshop in which they should learn to adopt observation, brainstorming and prototyping methods. They were also exposed to task-related videos and pictures of current situations and solutions, which resembled the observation phase. 
Participants in the control condition received no guidance on design thinking methods and were not exposed to these videos. However, videos were transcribed literally, so that participants in the control condition received the information in written form.

Participants in both conditions were informed about the innovation tasks and could ask comprehension questions. In essence, the subgroups were asked by the experimenters in intervals of 10 minutes whether there were any task-related issues to be clarified. Yet no serious misunderstandings arose.

\section{Experimental Procedure}

\section{Introduction}

Depending on the condition to which subjects were assigned, participants were invited for different time slots to ensure that subjects in different conditions did not meet each other.

When participants arrived at the project room, they were seated around a U-shaped table. At first, an experimenter gave a small introduction in which participants were informed about the experimental set-up and given some general rules, e.g. that they needed to switch off their mobile phones. Moreover, subjects were asked to briefly introduce themselves. Afterwards, the pre-task was presented.

\section{Pre-Task}

For the pre-task, participants were asked to develop five games that could be played in an office setting, based on a rope, a tennis ball and one additional piece of office equipment. This pre-task was selected because it was expected that all participants were equally knowledgeable on the topic.

Participants in the design thinking condition were then introduced to the design thinking process and its phases via a 15-minute presentation held by an expert from a consultancy 
specialized in that field. The supervision of a trained person should ensure that the design thinking process was implemented correctly. In more detail, participants received explanations on how to "observe" using videos \& pictures, how to conduct brainstorming sessions based on rules \& templates and how to build prototypes using sketches, flow charts $\&$ storyboards. These design thinking tools were selected because they were well suited to the selected tasks, were not based on additional equipment, could conceivably be learned by novice teams in a short period of time and because they are among the most commonly-used tools in design thinking contexts (Mahr et al, 2013). Notably, participants were not told that the process is called "design thinking" and the consultant was introduced as a general “external expert”.

After the introduction, participants in the design thinking condition were split into their subgroups and asked to do the pre-task. The participants received pens, papers and sheets on which the final five concepts needed to be written down. Furthermore, the groups in that condition were equipped with a ball and a rope in order to strengthen their idea prototyping capabilities. Moreover, they could ask the consultant in order to get support on how to apply the design thinking process. The combination of presentation and interactive design thinking workshop as a treatment was adapted from a case study on design thinking transformation within a company (Martin, 2011) and a study on design thinking with business and design students (Ungaretti et al., 2009). Notably, the consultants's personal influence should not alter the results. Therefore, the pre-task was used for the treatment, but its resulting outcomes were not used in the analyses later on.

Participants in the control group condition were given the same time frame, but they did not receive guidance from the consultant on how they should do the pre-task, were not exposed to videos of potential games (only pictures) and did not receive a ball and a rope. Nevertheless, they could ask the experimenter any task related questions, as mentioned earlier. Comparable 
to the design thinking condition, subjects in the control group condition were split into their five-person groups in which they should develop the games. Furthermore, subjects in the control group condition were equally equipped with pencils, papers and sheets to note down the concepts.

Having finished the pre-task, participants in both conditions handed in their concepts and came together to exchange their experiences with the other participants from the same condition. This step should further strengthen the understanding of approaches within groups of the respective condition. After a five minute break, main task A was presented.

\section{Main Tasks}

The main tasks should address a contemporary topic which has practical relevance and for which innovation is of high economic importance. The "challenge of eco sustainability" seemed to satisfy our criteria (cf. Brown, 2008; Nefiodow, 2006; Neumeier, 2008). Moreover, we wanted the novice teams to work out both tangible and intangible solutions, in order to enhance the generalizability of the findings. Therefore, we used two main tasks, whereby main task A centered on products while main task B on services and business models. Notably, it seemed conceivable that the application of the design thinking process felt easier for the product than for the non-product related task, so the product related task preceded the non-product related one.

For main task A, participants were asked to develop five concepts on how to generate electricity in everyday life based on a rotating mechanism. Participants were told that they could think about rotating systems where an electrical generator could be added, and about new approaches to how wind, water and or muscle power can be used to turn the electrical generator. The presentation for main task A encompassed background information on the energy market. Besides that, technical drawings and descriptions of current renewable energy 
generation systems based on turning parts, such as wind turbines and hydroelectric power plants were presented.

Participants in the design thinking condition were reminded during the task to apply the process learned and received additional videos of the presented solutions, which served as an input for the observation phase. As with the pre-task, the videos were summarized and the text was given to participants in both conditions. After 30 minutes, an experimenter collected the sheets on which the final concepts were noted.

For main task $B$, participants were asked to develop five services or business models based on smart meter's internet connection that energy companies could offer to private customers or households. The procedure for main task B was comparable to that for main task A. In the design thinking condition, videos were presented showing the job of a traditional meter reader and a man measuring electricity consumption in a household based on two electronic devices.

\section{Measurement}

Finally, each participant in both conditions individually filled out a questionnaire about their perception of the teamwork, their prior experiences and knowledge as well as personal demographics. In turn, subjects were thanked for participating, debriefed and handed out a voucher. The following table summarizes the experimental procedure and its two conditions. 
Table 4.1 Experimental Procedure

\begin{tabular}{|c|c|c|}
\hline Duration & Design Thinking Condition & Control Condition \\
\hline $10 \mathrm{~min}$. & \multicolumn{2}{|c|}{$\begin{array}{c}\text { - overview of the experimental setup } \\
\text { - explanation of basic rules (e.g. cell phones needed to be switched off) } \\
\text { - self introduction of participants }\end{array}$} \\
\hline $5 \mathrm{~min}$. & \multicolumn{2}{|c|}{ Presentation of pre-task } \\
\hline $15 \mathrm{~min}$. & $\begin{array}{l}\text { Presentation about the design thinking } \\
\text { process by trained consultant }\end{array}$ & \multirow[b]{2}{*}{$\begin{array}{l}\text { Pre-task: participants were spatially divided } \\
\text { according to the subgroup to which they } \\
\text { were assigned, received no rope and no } \\
\text { tennis ball and were not guided by external } \\
\text { consultant }\end{array}$} \\
\hline $30 \mathrm{~min}$. & $\begin{array}{l}\text { Pre-task: participants were spatially divided } \\
\text { into the subgroups to which they were } \\
\text { assigned, received a tennis ball and a rope, } \\
\text { were guided by consultant who explained how } \\
\text { to apply the design thinking process to the } \\
\text { pre-task }\end{array}$ & \\
\hline $10 \mathrm{~min}$. & \multicolumn{2}{|l|}{ Feedback } \\
\hline 5 min. & \multicolumn{2}{|c|}{ Break } \\
\hline $10 \mathrm{~min}$. & $\begin{array}{l}\text { Presentation of main task A including videos } \\
\& \text { pictures, transcribed texts and technical } \\
\text { drawings of current solutions }\end{array}$ & $\begin{array}{l}\text { Presentation of main task } A \text { including } \\
\text { transcribed texts and technical drawings of } \\
\text { current solutions }\end{array}$ \\
\hline $30 \mathrm{~min}$. & $\begin{array}{l}\text { Performing main task A: subgroups were } \\
\text { informed about time left (after 15, } 20 \text { and } 25 \\
\text { minutes) and reminded to apply the process }\end{array}$ & $\begin{array}{l}\text { Performing main task } A \text { : subgroups were } \\
\text { informed about time left (after 15, } 20 \text { and } \\
25 \text { minutes) }\end{array}$ \\
\hline $5 \mathrm{~min}$. & \multicolumn{2}{|c|}{ Break } \\
\hline $10 \mathrm{~min}$. & Presentation of main task B including videos & $\begin{array}{l}\text { Presentation of main task B without videos } \\
\text { (but transcribed text) }\end{array}$ \\
\hline $30 \mathrm{~min}$. & $\begin{array}{l}\text { Performing main task B: subgroups were } \\
\text { informed about time left (after 15, } 20 \text { and } 25 \\
\text { minutes) and reminded to apply the process }\end{array}$ & $\begin{array}{l}\text { Performing main task B; subgroups were } \\
\text { informed about time left (after 15, } 20 \text { and } \\
25 \text { minutes) }\end{array}$ \\
\hline $10 \mathrm{~min}$. & \multicolumn{2}{|c|}{ Measurement: Completion of questionnaire } \\
\hline 5 min. & \multicolumn{2}{|c|}{ Handout of vouchers and debriefing } \\
\hline
\end{tabular}

\section{Measures}

\section{Design Thinking}

Design thinking is assessed on a binary scale with 1 for the design thinking condition and 0

for the control condition.

\section{Teamwork \& Prior Design Thinking Experience}

Internal communication encompasses both communication openness (adapted from Hirst and

Mann, 2004) and communication frequency (adapted from Hoegl and Wagner, 2005).

Exploitation of external sources captures the degree to which information from external

sources was searched and processed (based on work by Narver et al., 2004). Group cohesion 
is based on the literature on work group integration and work group involvement (Rousseau et al., 2008; Hobman et al., 2004). Shared solution understanding is based on Hirst and Mann's (2004) "clarity of objectives" and captures the degree of clarity concerning suggested ideas among team members. The two items of prior design thinking experience reflect the extent to which participants were knowledgeable and familiar with the design thinking process prior to the experiment (Hirschman and Solomon, 1984).

\section{Idea Quality}

The concepts developed during the experiment were transcribed and randomized. Afterwards, two condition-blind raters, who had gained experience on innovation while working for a university-affiliated service consultancy, rated the concepts. The idea quality dimensions were evaluated based on the method and scales developed by Dean et al. (2006).

The process was as follows. At first, raters were informed about the experimental setting and the tasks participants had to solve. They also received the information that was provided to subjects during the experiment. Notably, raters were not informed about the purpose of the experimental study and the conditions. Subsequently, raters were introduced to the rating scales based on examples provided by Dean et al. (2006). As suggested by the authors, the concepts from the pre-task were in turn evaluated and the ratings discussed in order to get familiar with the methodology (Dean et al., 2006). More specifically, raters assigned scores from one to four to judge the novelty, feasibility and relevance of each concept and scores from one to three for the specificity of each concept. As mentioned earlier, the pre-task ratings were not used for the analyses, as the extraneous influence of the design thinking expert himself should not influence the results. Afterwards, the concepts developed during the main tasks were rated following the same scheme. These evaluations were done by the experts individually. However, the ratings for the first two concepts of each main task $(13.3 \%$ of all 
concepts from the main tasks) were discussed between raters after having evaluated them independently. This intermediate step should assure that both experts had the same understanding of the quality dimensions according to the respective task and set of concepts. After all of the concepts were evaluated, raters discussed discrepancies of two or more points on the scales and solved the discrepancies if possible.

\section{Analyses and Results}

\section{The Impact of Design Thinking on Teamwork (Analysis Stage 1: Participant Level)}

The analyses of this study are based on two units of analysis. For assessing the impact of design thinking on teamwork, the unit of analysis is the participant $\left(\mathrm{n}_{1}=30\right)$. The impact of design thinking on the teamwork variables was assessed based on partial least squares structural equation modeling using SmartPLS 2.0 (Ringle et al., 2005). Given the small sample size partial least squares structural equation modeling (PLS-SEM) better suited our objectives than covariance-based approaches (Reinartz et al., 2009). Besides that, the methodology allowed us to control for the influence of participants' prior design thinking experience, which we linked to all teamwork variables in the structural model.

Moreover, the methodology enabled us to examine inner relationship between the teamwork variables, which the authors from whom we adopted our preliminary framework already mentioned (Sivasubramaniam et al., 2012). Accordingly, we assessed whether the impact of design thinking on group cohesion is driven by internal communication and exploitation of external sources and whether group cohesion in turn influences shared solution understanding.

Before testing the structural model, the adequacy of the measurement models was tested. The teamwork variables were operationalized as latent variables with multiple items as described in the measures section above. Scale reliability was assessed based on item loadings. All loadings exceeded .5 , which suggests sufficient reliability. Convergent validity was assessed 
by examining the average variance extracted (AVE) values. All AVE values were above the threshold level of .5, which suggests convergent validity (Fornell and Larcker, 1981). In addition, composite reliability (CR) indicators were considered in order to assess internal consistency. The CR values range from .79 to .98 and thus are all greater than the recommended minimum of .7 (Fornell and Larcker, 1981), which is in support for the internal consistency of the measures. A summary of these results is attached in the appendix to this chapter.

In order to assess discriminant validity, it was checked whether the square root of each construct's AVE value exceeded all correlations of the respective constructs with the other latent variables (Fornell and Larcker, 1981; Wetzels et al., 2009). All square roots satisfied this criteria, as Table 4.2 demonstrates.

Table 4.2 Latent Variable Correlations - Analysis Stage 1

\begin{tabular}{lrrrrr}
\hline Constructs & $\mathbf{1}$ & $\mathbf{2}$ & $\mathbf{3}$ & $\mathbf{4}$ & $\mathbf{5}$ \\
\hline 1 Design Thinking & $n / a^{a}$ & & & & \\
2 Exploitation of External Sources & .28 & .75 & & & \\
3 Internal Communication & .61 & .52 & .83 & & \\
4 Group Cohesion & .20 & .43 & .51 & .81 & \\
5 Shared Solution Understanding & .02 & .68 & .44 & .65 & .76 \\
\hline Mean & .50 & 4.62 & 6.18 & 6.04 & 5.28 \\
Standard Deviation & .50 & 1.03 & .68 & .63 & .87 \\
AVE & $\mathrm{n} / \mathrm{a}$ & .57 & .69 & .65 & .57 \\
CR & $\mathrm{n} / \mathrm{a}$ & .87 & .90 & .93 & .79 \\
\hline
\end{tabular}

${ }^{\mathrm{a}}$ The square root of the average variance extracted (AVE) is on the diagonal.

Shedding more light on the model fit, we first assessed the variance explained in internal communication (40.8\%), exploitation of external sources (14.9\%), group cohesion $(33.8 \%)$ and shared solution understanding $(44.4 \%)$. The values indicated medium to large effect sizes (Cohen, 1988). Moreover, we applied the $\mathrm{R}^{2}$-based global goodness-of-fit (GoF) equation suggested by Tenenhaus et al (2005), resulting in a GoF- index of .48, which is above the recommended threshold level of .35 . 
In turn, we assessed the path coefficients and t-values in SmartPLS 2.0 (Ringle et al. 2005) using the bootstrapping option with 500 samples (Chin, 1998). The results revealed that design thinking significantly drives internal communication $(\beta=.63, p<.01)$, thus pointing in the expected direction. Moreover, design thinking has a direct positive effect on exploitation of external sources $(\beta=.31, \mathrm{p}<.05)$.

Against our expectations, there was no direct effect of design thinking on group cohesion ( $\beta=$ $-.12, \mathrm{p}>.10)$ and shared solution understanding $(\beta=-.09, \mathrm{p}>.10)$. However, the results revealed that internal communication has a positive influence on group cohesion $(\beta=.49, \mathrm{p}<$ $.01)$ and group cohesion in turn positively influences shared solution understanding $(\beta=.63, p$ $<.01)$. Notably, exploitation of external sources had no influence on group cohesion $(\beta=.17$, $\mathrm{p}>.10)$

\section{The Impact of Design Thinking on Idea Quality (Analysis Stage 2: Idea Level)}

In order to assess the impact of design thinking on idea quality, the idea ratings described above are used. Thus, the major entity in this analysis stage is the idea $\left(n_{2}=60\right)$. Before conducting the actual analysis, inter-rater reliability for idea quality was assessed based on Pearson's r. In particular, the ratings for all quality dimensions were aggregated per rater and the two sets of ideas and then correlated using SPSS 20.0 (IBM Corp., 2011). The overall agreement of raters was $r=.75$. Given the high correlation, the scores assigned by the raters were averaged for each idea and item.

In order to test the impact of design thinking on idea quality we again used SmartPLS 2.0 (Ringle et al., 2005) and linked design thinking to each quality dimension. The quality dimensions were operationalized as latent variables with single items. The descriptive statistics are provided in the correlation matrix below (Table 4.3). 
Table 4.3 Latent Variable Correlations - Analysis Stage 2

\begin{tabular}{lrrrrr}
\hline Constructs & $\mathbf{1}$ & $\mathbf{2}$ & $\mathbf{3}$ & $\mathbf{4}$ & $\mathbf{5}$ \\
\hline Design Thinking & $n / \mathrm{a}^{\mathrm{a}}$ & & & & \\
2 Novelty & .32 & $\mathrm{n} / \mathrm{a}$ & & & \\
$3 \quad$ Feasibility & -.14 & -.08 & $\mathrm{n} / \mathrm{a}$ & & \\
$4 \quad$ Relevance & .28 & .14 & -.01 & $\mathrm{n} / \mathrm{a}$ & \\
$5 \quad$ Specificity & .23 & .25 & .09 & .34 & $\mathrm{n} / \mathrm{a}$ \\
\hline Mean & .50 & 2.83 & 3.11 & 3.58 & 2.42 \\
Standard Deviation & .50 & .81 & .55 & .75 & .65 \\
AVE & $\mathrm{n} / \mathrm{a}$ & $\mathrm{n} / \mathrm{a}$ & $\mathrm{n} / \mathrm{a}$ & $\mathrm{n} / \mathrm{a}$ & $\mathrm{n} / \mathrm{a}$ \\
CR & $\mathrm{n} / \mathrm{a}$ & $\mathrm{n} / \mathrm{a}$ & $\mathrm{n} / \mathrm{a}$ & $\mathrm{n} / \mathrm{a}$ & $\mathrm{n} / \mathrm{a}$ \\
\hline
\end{tabular}

${ }^{a}$ The square root of the average variance extracted (AVE) is on the diagonal

Given the single item scales, adequacy of the measurement model could not be tested.

Focusing on the model fit, the variances explained in novelty $(10.3 \%)$, feasibility $(1.9 \%)$, relevance (7.9\%) and specificity (5.5\%) suggest small to medium effect sizes (Cohen, 1988).

The path coefficients and t-values were calculated in SmartPLS 2.0 (Ringle et al., 2005) using the bootstrapping option with 500 samples as suggested by Chin (1998). In line with our expectations, the results revealed that design thinking has a significant positive influence on novelty $(\beta=.32, \mathrm{p}<.01)$, relevance $(\beta=.28, \mathrm{p}<.01)$ and specificity $(\beta=.23, \mathrm{p}<.05)$. However, the results showed that design thinking does not enhance feasibility $(\beta=-.14, p>$ .10). The aforementioned results are summarized below. 
Table 4.4 Summary of Tested Influences and Results

\begin{tabular}{lc}
\hline Tested Influences in Analysis Stage 1 & B-Coefficient \\
\hline Design Thinking $\rightarrow$ Exploitation of External Sources & $.31^{* *}$ \\
Design Thinking $\rightarrow$ Internal Communication & $.63^{* *}$ \\
Design Thinking $\rightarrow$ Group Cohesion & -.12 \\
Design Thinking $\rightarrow$ Shared Solution Understanding & -.09 \\
Internal Communication $\rightarrow$ Group Cohesion & $.49^{*}$ \\
Exploitation of External Sources $\rightarrow$ Group Cohesion & .17 \\
Group Cohesion $\rightarrow$ Shared Solution Understanding & $.63^{\star *}$ \\
\hline Tested Influences in Analysis Stage 2 & B-Coefficient \\
\hline Design Thinking $\rightarrow$ Novelty & $.32^{* *}$ \\
Design Thinking $\rightarrow$ Feasibility & -.14 \\
Design Thinking $\rightarrow$ Relevance & $.28^{* *}$ \\
Design Thinking $\rightarrow$ Specificity & $.23^{*}$
\end{tabular}

${ }^{* *} p \leq .01 ;{ }^{*} p \leq .05$ (all effects one-sided)

\section{Post-Hoc Analysis: The Impact of Teamwork on Idea Quality}

As we gathered data concerning the teamwork from participants and data concerning idea quality from external raters, we needed to aggregate the data for teamwork and idea quality each to the group level $\left(n_{3}=6\right)$. Given the resulting small sample size, we were not able to draw inferences about single relationships between teamwork variables and idea quality dimensions. Yet, for the sake of completeness and in order to explore the general relationship between those design thinking outcomes, a post-hoc analysis was conducted. In essence, we averaged the values for the teamwork variables and idea quality dimensions and investigated their relationship by calculating Kendall's tau-b correlation coefficient. The results point to a positive correlation between the two variables $\left(\tau=.57, \mathrm{n}_{3}=6, \mathrm{p}>.10\right)$, with high levels of teamwork associated with higher levels of innovation idea quality. However, the results were not significant.

\section{Overview of the Effects Assessed}

The following Figure 4.2 provides a summary of the effects assessed and suggests a refined model of the impact of design thinking. 
Figure 4.2 Assed Influences of Design Thinking on Performance Outcomes

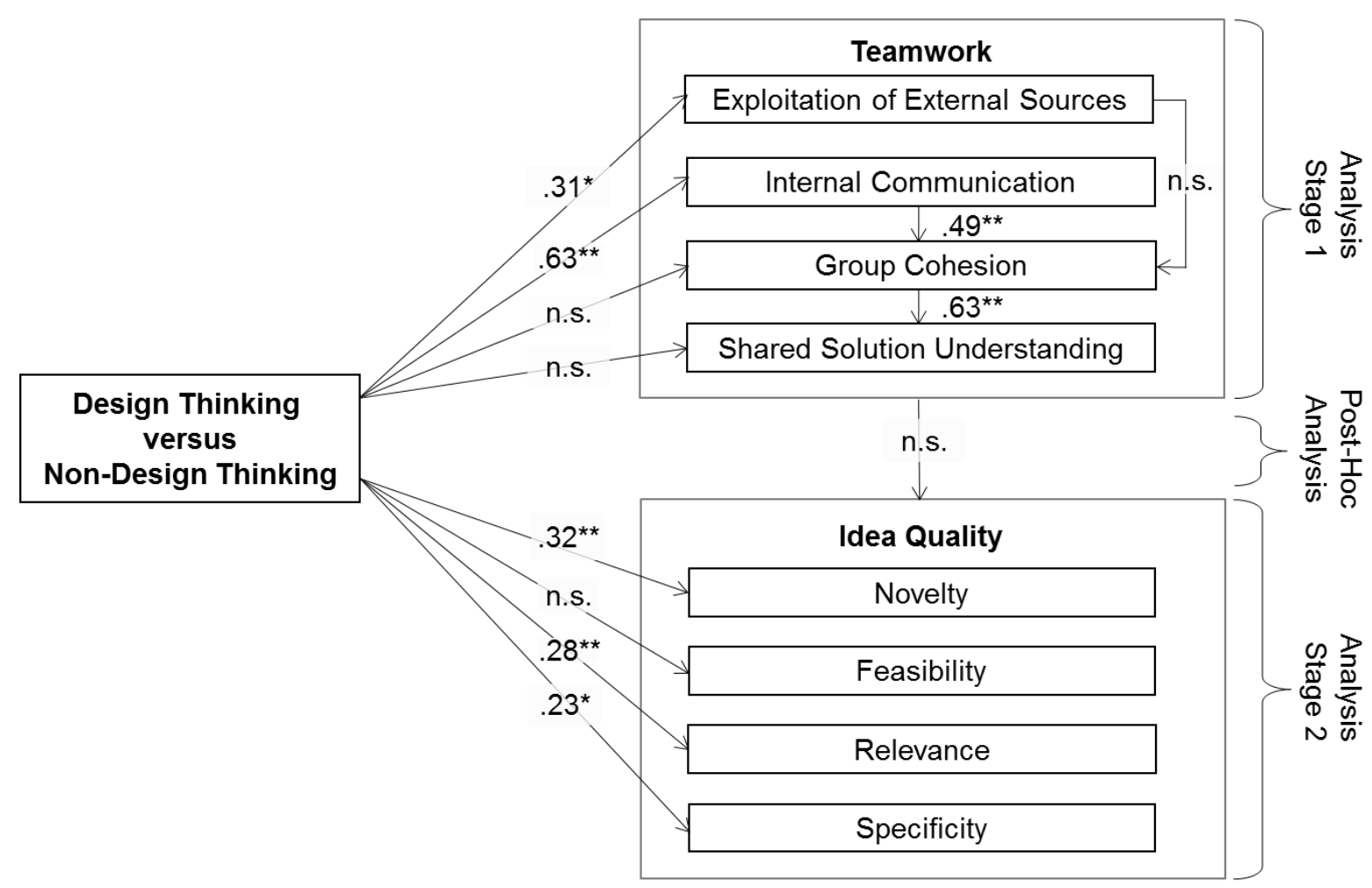

n.s. $=$ not significant; ${ }^{* *} p \leq .01 ;{ }^{*} p \leq .05$ (all effects one-sided)

\section{Discussion and Conclusion}

The recent literature on design thinking as an innovation front end process is based on anecdotal, rather than empirical investigations, with only a few exceptions (JohanssonSköldberg et al., 2013) and lacks a comprehensive, theoretical foundation. Study 3 addresses these research gaps and suggests a conceptual model of the impact of design thinking on front end teamwork and idea quality. In doing so, we make several important contributions to the emerging literature on design thinking, as will be discussion below. 


\section{Theoretical Implications}

\section{The Benefits of Design Thinking for Front End Team Work}

Adding to previous, often practice-based studies on design thinking that focused predominantly on the process and its output, this study takes into account how teamwork factors are positively influenced by design thinking.

In line with our expectations, we found a positive direct impact of design thinking on internal communication and exploitation of external sources. Thus, design thinking seems to not only strengthen the information exchange within the team, but also the degree to what information from outside the team is searched and processed. The assessed positive influence on internal communication suggests that the often-stated notion that designers and design tools help to span language boundaries between team members (see also Veryzer et al., 2005; Calabretta et al., 2008; Woodward, 2010 for related discussion), also applies to the adoption of design thinking in novice teams.

Against our expectations, we did not find empirical support for the assumed direct impact of design thinking on group cohesion and shared solution understanding. However, our analysis revealed a positive influence of internal communication on group cohesion and a positive influence of group cohesion on shared solution understanding, which is in line with the findings of Sivasubramaniam et al. (2012) from which we adopted our framework. Thus, our findings suggest that the personal bonds within the team are not directly affected by implementing the design thinking process in novice teams, but rather indirectly through the enhanced communication among team members. Moreover, group members' better understanding of proposed solutions seems to result from stronger personal relationships among team members rather than the use of idea prototypes as expected based on extant case studies (e.g. Brown, 2008). 


\section{The Benefits of Design Thinking for Idea Quality}

Study 3 advances design thinking research by assessing the impact of the process on four distinct rather than one aggregated dimension of idea quality(Wattanasupachoke, 2012; Seidel and Fixson, 2013). In particular, these findings demonstrate that the implementation of design thinking yields more novel ideas, which confirms the results of prior studies (Wattanusapachoke, 2012; Seidel and Fixson, 2013). In addition, our results indicate that novice teams using design thinking develop more relevant and more specific ideas than teams which do not use this process. Given the present interpretation of idea relevance, as the degree to which the idea applies to a certain problem (adapted from Dean et al., 2006), the enhanced relevance supports the conception of design thinking as a problem solving process (Kimbell, 2011). Besides this, higher degrees of specificity in design thinking groups underline our notion that the process provides a more complete picture of the implications of the ideas. This finding provides some initial support for the assumption that design thinking encourages team members to assess cause-and-effect relationships of the developed idea that would otherwise remain uncovered (see Brown and Wyatt, 2010 for related discussion).

In contrast to our expectations and against the opinion of design thinking pioneers, the results did not support that design thinking leads to more feasible ideas. This result may be traced back to a rivalry between the constraints of a project. In particular, Brown (2009) argues that design thinking encourages team members to balance what is desirable from a user perspective with what is economically viable and technically feasible. However, Brown (2009) also mentions that not all of these three aspects are equally important in all projects. Building up on this perspective, the present results may mirror that the selected tasks have shifted participants' attention towards the desirability from a user perspective - as reflected by the enhanced idea relevance - while partially neglecting which suggested solutions are actually viable or feasible. 


\section{The Impact of Front End Teamwork on Idea Quality}

Finally, our results point to a positive relationship between front end teamwork and idea quality. However, the results were not significant, which may be traced back to the small number of observations in this analysis stage. Nevertheless, the positive direction of the analyzed relationship somewhat confirms the findings of previous work that assessed comparable impacts of group variables on performance outcomes (e.g. Hülsheger et al., 2009; Sivasubramaniam et al., 2012). Thus, it seems conceivable that an analysis based on a larger dataset may reveal that the improvement in teamwork, derived from an application of the design thinking process, is actually a substantial driver of the enhanced idea qualities.

\section{Managerial Implications}

Study 3 provides managers who seek to implement design thinking within their front end activities with empirical support in order to justify their efforts. In particular, our findings demonstrate that the design thinking process can be a useful tool to trigger internal team communication and enhance information gathering and processing from external sources. These factors are important aspects for managers in order to strengthen the personal relationships among team members, increase team members' understanding of proposed solutions and enrich the ideation process with external information from various stakeholders. In turn, teams applying the design thinking process are able to develop more original, problem-centered and specific innovation concepts. Taken together, the design thinking process offers managers a structured approach to achieve both an enhanced teamwork and a higher quality innovation output.

Moreover, our experimental procedure, which we derived from the literature (cf Martin, 2011; Ungaretti et al., 2009), provides managers with a blueprint for successfully implementing the design thinking process among novice teams. In particular, three steps can be judged as being 
useful triggers for implementing the process. At first, team members are informed about the design thinking phases via presentations. Second, the group applies the process to an abstract task, which enables team members to understand the basic concept and its benefits. This step should be supervised by a trained expert in order to assure that the concept is understood and applied correctly. Finally, teams should adopt the process to specific innovation tasks they are confronted with in their business.

Focusing on the coaching aspect in our experiment, the results underline that offering design thinking presentations and workshops can be a new business opportunity for design and management consultancies. Managers of these companies may use our approach to develop their own offerings and our results in order to back up its usefulness.

\section{Limitations and Suggestions for Further Research}

Despite contributing to the design thinking discourse, this study is not without limitations that might be addressed by further research. First, given the exploratory nature of the study, we only used a small number of teams in the experimental design. A greater sample power may offer more insights into the relationships within the model, such as that between teamwork and idea quality. Second, although our laboratory experiment enabled us to control for certain extraneous influences while using realistic tasks, it did not allow us to differentiate which design thinking steps drove the dependent variables most. Thus, further research may use components of the process in parallel or compare different approaches in order to shed more light on their effectiveness. Finally, our experiment allowed for design thinking to be implemented only for a very short period of time. However, authors have already indicated that the capabilities to use the process (Sato, 2009) and its phases (Sutton and Hargadon, 1996) increase with experience. Thus, a more longitudinal study may shed more light on how design thinking effectiveness increases over time. 


\section{Appendix - Constructs}

\begin{tabular}{lc}
\hline Construct & Loading \\
\hline Internal Communication & \\
(7-point scale: 1 = "strongly disagree", 7= "strongly agree") & .68 \\
Team members could express their views openly. & .88 \\
Ideas were openly evaluated by team members. & .90 \\
Between the members of our team, communication was frequent. & .85 \\
There was an ongoing discussion within our team. &
\end{tabular}

\section{Exploitation of External Sources}

(7-point scale: 1 = "strongly disagree", $7=$ "strongly agree")

We tried to discover customer needs of which they are unaware. $\quad .78$

We incorporated solutions to unarticulated customer needs in our ideas. $\quad .88$

We brainstormed on how customers use our products and services.

We searched for opportunities in areas where customers have a difficult time expressing their needs.

We tried to gain insights into what users in the current market will need in the future.

\section{Group Cohesion}

(7-point scale: $1=$ "strongly disagree", $7=$ "strongly agree")

I had good relationships with my team members.

There was closeness between my team members and me. $\quad .85$

I got support from my team members. $\quad .90$

$\begin{array}{ll}\text { I felt isolated from the team. }(r) & .78\end{array}$

People in the team listened to what I said. $\quad .57$

My judgment was respected by members of the team. $\quad .75$

Team members made me feel a part of decisions. $\quad .88$

\section{Shared Solution Understanding}

(7-point scale: 1 = "strongly disagree, $7=$ "strongly agree")

Team members had a clear understanding of suggested ideas within the team.

Suggested solutions were understood by all team members in detail. $\quad .66$

There was a lack of clarity concerning suggested ideas. ( $r$ )

\section{Prior Design Thinking Experience}

Prior to this experiment, design thinking processes were...

7-point scale: $1=$ "known to me", 7 = "not known to me" $(r)$

7-point scale: $1=$ "familiar to me", 7= "not familiar to me $(r)$ 
CHAPTER 5. CONCLUSION 


\section{Synopsis}

This dissertation was motivated by the observation that firms have become increasingly interested in deciphering the DNA of design-oriented companies and have started to apply design processes, principles and tools to various innovation contexts (e.g. Brown, 2009; Martin, 2009). In recent years, design has evolved from a product-centered discipline dominated by designers to a broader concept that includes organizational dimensions (Beckman and Barry, 2007; Brown, 2009; Cooper et al., 2010). Yet, outcome-based design research is highly fragmented and discourses have predominantly taken place within literature streams, although it has already been suggested that cross-fertilization may provide a more holistic picture of the design success phenomena (Ravasi and Stigliani, 2012). By taking a glance beyond the borders of the different fields, the present dissertation aimed at providing a better understanding of design orientation of firms and design thinking as a process for innovation's fuzzy front end. In order to reach this goal, three studies were carried out.

\section{Study 1. A Systematic Review of Research on Design Success: Synthesizing Design Perspectives, Responses and Returns}

In study 1 , we systematically reviewed the outcome-based literature on design across three distinct research streams in order to synthesize the various perspectives on design success.

First, we developed a conceptual framework that demonstrates how design impacts people, organizations and stock markets, in which contexts these influences have been assessed and how the impact of design has been measured. In doing so, we have contributed to the outcome-based literature on design by providing a more integrative perspective on design success. In particular, we have demonstrated that the design management literature focuses on the influence of organizational design emphasis and excellence on financial results, whereas the emerging research on design thinking investigates the impact of new design approaches 
and applications on non-financial results. Besides this, we have shown that the traditional design research, which takes a design output perspective, has not yet begun to explore intangible design outputs, but continues to carry out studies at the customer-product interface. By comparing these literature streams, we have also developed a more holistic understanding of the theoretical considerations and empirical findings within the literature streams, which build the foundation for developing the frameworks in the subsequent two studies.

Second, we have opened new avenues for further research by uncovering and highlighting white spots within and across literature streams that might be worth addressing by further research. For instance, the review uncovered a lack of a managerial framework within the design management literature, which the second study sought to address. Moreover, the emerging literature on design thinking turned out to be mainly based on anecdotal evidence rather than theoretical foundations and empirical investigations. Therefore, the third study addressed this latter issue.

\section{Study 2. Design Orientation of Firms: Conceptualization and Empirical Investigation of its}

\section{Antecedents and Innovation Outcomes}

In study 2, we focused on design orientation on a firm level and selected an innovation management benchmarking database, which allowed us to investigate the antecedents and outcomes of such an orientation.

First, we conceptualized design orientation against the backdrop of previous descriptions and definitions of the phenomena (cf. Beverland and Farrelly, 2007; Calabretta et al., 2008; Hart et al., 1989; Kotler and Rath, 1984; Moultrie and Livesey, 2014; Venkatesh et al., 2012). Most notably, we encompassed the cultural and processual dimensions, highlighted within the design thinking literature, in our conceptualization. Hence, we have extended previous 
investigations in the innovation and design management literature, by adopting a more recent, broader perspective of design orientation, which transcends organizations.

Second, we adopted an established innovation management framework and developed rationales that explain the antecedents of design orientation. Moreoever, we have been the first to offer empirical insights on the drivers of design orientation. In particular, we have found that top management attitude toward innovation, the profound implementation of an innovation strategy, organizational involvement during the innovation process, and formalization of the innovation process enable design orientation, while - unexpectedly - a favorable attitude of employee to innovation does not. Moreover, our findings suggest that collaboration with external innovation partners seems to deflect from a thorough implementation of firm-internal innovation activities (i.e., innovation strategy implementation and organizational innovation involvement) since their positive impact on design orientation is weakened in case of extensive involvement of external partners.

Third, we inspected the influence of design orientation on three innovation outcomes and extended prior investigations by assessing their interconnectedness as well as potential contingency effects on these outcomes. In particular, our findings demonstrate that the influence of design orientation on financial innovation returns is partially mediated by the effectiveness and efficiency of a firm's innovation process. In contrast to prevailing theory, the influence of design orientation on innovation process effectiveness and efficiency increases if companies focus on radical rather than incremental innovation projects. At the same time, design orientation has appeared to have a greater influence on process efficiency if the company dominantly engages in product (rather than service) related innovations. 


\section{Study 3. Design Thinking during the Fuzzy Front End: An Exploration of the Impact of Design Thinking on Teamwork and Idea Quality}

In study 3 , we turned to the team level and explored the impact of design thinking as an innovation front end process. Hence, we recruited non-design students from a European university and put them together to resemble innovation teams in order to study how the application of the design thinking process influences their teamwork and the quality of their innovation output respectively.

First, we explored the impact of design thinking through the lens of an innovation team framework. In doing so, we extended prior studies on design thinking, which focused predominantly on the process and its outputs. In particular, we found that design thinking enhances communication among team members and the exploitation of external sources. The first finding indicates that the often-stated notion about designers and design processes to span language boundaries between team members (e.g. Calabretta et al., 2008; Veryzer and Borja de Mozota, 2005; Woodward, 2010), also applies to design thinking when being applied by novice teams. An enhanced exploitation of external sources confirms conjectures in line with prior studies (e.g. Beckman and Barry, 2007), that design thinking yields insights which might be overseen based on more traditional research approaches. Furthermore, we found a positive influence of internal communication on group cohesion and a positive influence of group cohesion on shared solution understanding, which is in line with the findings of Sivasubramaniam et al. (2012) from which we adopted our framework.

Second, we inspected four dimensions of innovation output quality, whereas prior investigations used only one (Seidel and Fixson, 2013; Wattanasupachoke, 2012). In particular, we found that design thinking does not only enhance the innovation outputs' novelty, which is in line with prior investigations (Seidel and Fixson, 2013; Wattanasupachoke, 2012), but also its relevance and specificity. Yet, against our expectations, 
design thinking does not improve the innovation output in terms of its feasibility.

Nevertheless, the findings provide initial empirical support for the assumption that design thinking is a valuable trigger for early innovation outputs.

Finally, our results indicate an overall positive influence of teamwork on innovation output quality, which is in line with prevailing theory in innovation management. Yet, the data was not sufficient to properly examine single relationships between teamwork factors and innovation output dimensions, which provides avenues for further investigations.

The following table provides an overview of the key findings.

Table 5.1 Overview of the Key Findings per Study

\section{Study Key Findings}

Study 1 - Design as part of an organization or output can be a valuable driver of people's designled responses, organizational performances and shareholder returns.

- The impact of designers, design processes and design outputs has been quantitatively assessed in numerous ways and across various industries.

- The extant studies on design success within a literature stream (i.e. design management, design thinking or design output) have predominantly focused on the same design outcome categories.

- The established, empirically-based design management literature could benefit from the theoretical considerations of the emerging design thinking literature.

Study 2 - A firm's design orientation requires managers with a positive attitude toward innovation, an extensively implemented innovation strategy, broad organizational involvement, and greater formalization of the innovation process.

- The involvement of external partners in innovation contexts weakens the impact of an extensively implemented innovation strategy and a broad organizational involvement on design orientation.

- Design oriented companies benefit from improved innovation process efficiency and effectiveness and, ultimately, greater financial innovation returns.

- Employing design processes, principles, and tools drives innovation performance, especially in firms that focus on radical rather than incremental innovations and it also appears more suitable for product rather than non-product innovations.

Study 3 - Design thinking presentations and workshops can help novice teams to adopt observation, brainstorming and idea prototyping steps during the fuzzy front end.

- The design thinking process appears to enhance teams' internal communication and their exploitation of external sources, while in turn internal communication drives group cohesion and ultimately group cohesion drives team members' shared solution understanding.

- Idea novelty, relevance and specificity are positively influenced by the design thinking process, while idea feasibility is not. 


\section{Implications for Managers, Academia and Policy Makers}

The three studies yield manifold managerial implications, each of which have been highlighted earlier. Nevertheless, we would like to make six concluding remarks on how to foster the widespread use of design processes, principles and tools on a corporate as well as on a project level in order to spur innovation.

First, managers should develop a positive attitude toward innovation, implement a profound innovation strategy, involve the organization in innovation processes and formalize the innovation process in order to enable design to transcend the organization and in turn benefit from an enhanced innovation performance. In this context, special attention should be paid to its embeddedness in the firm's overall open innovation strategy, as high degrees of external collaboration may hinder a company from becoming design orientated, because it may deflect the focus from design and onto a broad set of collaborators.

Second, managers who seek to improve teamwork and innovation output quality during the fuzzy front end of innovation projects, should implement the design thinking process within teams based on three steps. Initially, team members should be exposed to presentations about the process, whereby important aspects of the phases are highlighted. In a second step, teams should learn to apply the process to an abstract task, in order to enable team members to understand and learn the basic concept. During this second step, a trained expert should guide the process in order to answer questions and coach the team when going through the phases. Finally, the team should adopt the process to its actual innovation tasks. Doing so does not only improve the ultimate innovation output, but also the teamwork, which further leverages innovation's quality.

Third, managers should not limit the use of design to product and incremental innovation projects, but instead support non-designers to apply design processes, principles and tools to a 
variety of innovation types and outcomes. Especially radical innovation projects seem to gain from the widespread use of design tools and should therefore adopt them, because the value of the tools in foreseeing the final innovation outcome increases with the newness of the innovations as well as the uncertainty resulting from the unpredictable adoption of radical innovations within the market.

Fourth, managers and researchers interested in evaluating the benefits of design efforts should focus not only on design outputs and financial returns, but also take a look within the organization and on non-financial results. In particular, the impact of design orientation on a firm level should also be assessed in terms of innovation process efficiency and effectiveness as both have been shown to gain from an implementation of design throughout the organization. On a project level, applications of design thinking within innovation front end processes should be evaluated in terms of teamwork, as the team's internal communication and exploitation of external sources also benefit from this process.

Fifth, scholars from business schools and other non-design related fields should consider adopting design processes, principles and tools in their curricula and group work sessions. Lectures may be enriched by success stories on new design applications and case studies may encourage consumer observations, brainstorming guidelines and idea prototyping tools. Doing so can improve students' teamwork skills, enhance their effectiveness and efficiency when working on projects and ultimately improve their innovation outputs.

Sixth, policy makers should support the widespread use of design to spur innovativeness by building networks that geographically and mentally blur the boundaries between design and other disciplines. In particular, policy makers could promote the establishment of institutions that initiate conferences in which practitioners present case studies on successful new design applications and researchers from different fields of study present their most recent findings. 
The outcomes of these sessions may then be published and spread through trade associations and universities, which would further disseminate the use of design processes across industries and encourage further research on that topic among academia.

\section{Suggestions for Further Research}

Directions for future research have been discussed for each of the three studies. Yet, we finally take a more holistic perspective and discuss some general options for further investigations on design orientation and design thinking.

Our studies have demonstrated that design transcending organizations and its application as a process during the fuzzy frond end of innovation projects improve innovation performance. Yet, we did not compare the concepts' performances against those of other approaches. However, direct comparisons between the performance of design concepts and that of other management approaches would shed new light on the superiority of the selected method and in turn provide valuable implications on their usefulness.

Another avenue for further investigations arises by shifting the perspective away from economic performance towards a broader set of performance indicators. In the preceding chapters, a substantial proportion of the success of design efforts was explained by the notion that design enables companies or project teams to review new product concepts (tangible and intangible) from various perspectives (e.g. Borja de Mozota, 2003; Brown, 2009; Calabretta et al., 2008; Woodward, 2010). Against the backdrop of this notion, design-oriented companies and teams applying design thinking are likely to consider various stakeholder groups when assessing new concepts. In this light, further research might, for instance, examine whether design-oriented firms act more environmental or social responsibly than other firms.

Finally, it might be of interest to investigate design orientation and design thinking in nonbusiness contexts. In fact, universities as well as primary and secondary schools have started 
to explore design thinking as part of their curricula. In addition, the design and innovation consultancy IDEO has recently launched a design thinking toolkit for educators. Given these developments, future research might want to investigate how design processes could be applied within educational institutions and in turn lead to a better learning environment as well as more innovative graduates.

\section{Final Thought}

Capturing and explaining design success phenomena in innovation management contexts is a complex and challenging task. This thesis addresses this issue by framing the overall impact of design and examining its drivers and innovation outcomes on a corporate as well as on a project level in three distinct, yet interrelated studies. The central premise of this dissertation is that the economic benefits of design efforts can only partially be traced back to tangible outputs, but rather that a substantial proportion of its success can be ascribed to the managerial, processual, and cultural aspects of design transcending companies and guiding innovation projects. Building upon theoretical considerations and empirical findings from the design management, design thinking and innovation management literature, this thesis seeks to provide a more holistic perspective on design applications and their impacts on innovation outcomes. In doing so, it is hoped that this dissertation contributes to a better understanding of the benefits of design among researchers and managers alike. To conclude with the words of Steve Jobs, "design is not just what it looks like and feels like, design is how it works." 


\section{REFERENCES}

Acklin, C. (2010). Design-driven innovation process model. Design Management Journal, $5(1), 50-60$.

Antioco, M., Moenaert, R.K., Lindgreen, A., and Wetzels, M.G.M. (2008). Organizational antecedents to and consequences of service business orientations in manufacturing companies. Journal of the Academy of Marketing Science, 36(3), 337-358.

Aspara, J. (2009a). How do institutional actors in the financial market assess companies' product design? The quasi-rational evaluative schemes. Knowledge, Technology and Policy, 22(4), 241-258.

Aspara, J. (2009b). Where product design meets investor behavior: How do individual investors' evaluations of companies' product design influence their investment decisions? Helsinki: Publication series of the University of Art and Design Helsinki A 99. Retrieved from: http://eprints.herce.fi/168/1/where_product_design_meets_investor_behavior.pdf.

Association of Swedish Engineering Industries and the Swedish Industrial Design Foundation. (2005). 10 Points: Attitudes, profitability and design maturity in Swedish companies. Retrieved from: http://www.svid.se/ upload/For_foretag/ Undersokningar/Folder_10_points.pdf.

Beckman, S.L., and Barry, M. (2007). Innovation as a learning process: Embedding design thinking. California Management Review, 50(1), 25-56.

Beckman, S.L., and Barry. M. (2008). Developing design thinking capabilities. Step Inside Design, 24(4), 82-88.

Bell, S.J. (2008). Design thinking. American Libraries, 39(1/2), 44-49.

Berkowitz, M. (1987). Product shape as a design innovation strategy. Journal of Product Innovation Management, 4(4), 274-283.

Beverland, M.B., and Farrelly, F.J. (2007). What does it mean to be design-led? Design Management Review, 18(4), 10-17.

Black, C.D., and Baker, M.J. (1987). Success through design, Design Studies, 8(4), 207-216.

Bloch, P.H. (1995). Seeking the ideal form: Product design and consumer response. Journal of Marketing, 59(7), 16-29.

Bloch, P.H., Brunel, F.F., and Arnold, T.J. (2003). Individual differences in the centrality of visual product aesthetics: Concept and measurement. Journal of Consumer Research, 29(3), 551-565.

Borja de Mozota, B. (2002). Design and competitive edge: A model for design management excellence in European SMEs. Design Management Review, 2(1), 88-104.

Borja de Mozota, B. (2003). Design management: Using design to build brand value and corporate innovation. Allworth Press, New York. 
Borja de Mozota, B. (2006). The four powers of design: A value model in design management. Design Management Review, 17(2), 44-53.

Brown, T. (2008). Design thinking. Harvard Business Review, 86(6), 84-92.

Brown, T. (2009). Change by design: How design thinking transforms organizations and inspires innovation. New York, NY: HarperCollins.

Brown, T., and Wyatt, J. (2010). Design thinking for social innovation. Stanford Social Innovation Review, 8(1), 31-35.

Calabretta, G., Montana, J., and Iglesias, O. (2008). A cross-cultural assessment of leading values in design-oriented companies. Cross Cultural Management: An International Journal, 15(4), 379-398.

Candi, M. (2006). Design as an element of innovation: Evaluating design emphasis in technology-based firms. International Journal of Innovation Management, 10(4), 351374.

Candi, M. (2007). The role of design in the development of technology-based services. Design Studies, 28(6), 559-583.

Candi, M. (2010). Benefits of aesthetic design as an element of new service development. Journal of Product Innovation Management, 27(7), 1047-1064.

Candi, M., and Saemundsson, R.J. (2011). Exploring the relationship between aesthetic design as an element of new service development and performance. Journal of Product Innovation Management, 28(4), 536-557.

Center for Design Innovation. (2007). The design difference: A survey of design and innovation amongst Ireland's SMEs. Retrieved from: http://www.designinnovation.ie/downloads/TheDesignDifference2007.pdf.

Chin, W.W. (1998). The partial least squares approach to structural equations modeling. In G.A. Marcoulides (Eds.), Modern Methods for Business Research. Lawrence Erlbaum (pp. 295-336), London, Great Britain.

Chin, W., Marcolin, B.L., and Newsted, P.R. (2003). A partial least squares latent variable approach for measuring interaction effects: Results from a Monte Carlo simulation study and an electronic mail emotion/adoption study. Information Systems Research, 14(2), 189-217.

Chitturi, R., Raghunathan, R., and Mahajan, V. (2007). Delight by design: The role of hedonic versus utilitarian benefits. Journal of Marketing, 72(3), 48-63.

Chiva, R., and Alegre, J. (2009). Investment in design and firm performance: The mediating role of design management. Journal of Product Innovation Management, 26(4), 424-440.

Chiva, R., Alegre, J., and Lapiedra, R. (2004). A model of product design management in the Spanish ceramic sector. European Journal of Innovation Management, 7(2), 150-161.

Clark, K.., and Smith, R. (2008). Unleashing the power of design thinking. Design Management Review, 19(3), 8-15. 
Clemente, M.N., and Greenspan, D.S. (1999). Culture clashes. Executive Excellence, 16(10), 12.

CNNMoney (2014). Most admired, Retrieved from:

http://money.cnn.com/magazines/fortune/most-admired/2014/list/.

Cohen, J. W. (1988). Statistical power analysis for the behavioral sciences. $2^{\text {nd }}$ Edition. New Jersey: Lawrence Erlbaum Associates.

Cooper, R., Junginger, S., and Lockwood, T. (2010). Design thinking and design management: A research and practice perspective. In Thomas Lockwood (Eds.), Design thinking: Integrating innovation, customer experience and brand value (pp. 57-64). New York, NY: Allworth.

Cooper, R.G., and Kleinschmidt, E.J. (1991). New product processes at leading industrial firms. Industrial Marketing Management, 20(2), 137-147.

Cooper, R.G., and Kleinschmidt, E.J. (1993). Screening new product for potential winners. Long Range Planning, 26(6), 74-81.

Cooper, R.G., and Kleinschmidt, E.J. (1995). Benchmarking the firm's critical success factors in new product development. Journal of Product Innovation Management, 12(5), 374391.

Cooper, R.G., and Kleinschmidt, E.J. (2007). Winning businesses in product development: The critical success factors. Research Technology Management, 50(3), 52-66.

Creusen, M.E.H., Veryzer, R.W., and Schoormans, J.P.L. (2010). Product value importance and consumer preference for visual complexity and symmetry. European Journal of Marketing, 44(9), 1437-1452.

Crilly, N., Moultrie, J., and Clarkson, P.J. (2004). Seeing things: Consumer response to the visual domain in product design. Design Studies, 25(6), 547-577.

Crossan, M.M., and Apaydin, M. (2010). A multi-dimensional framework of organizational innovation: A systematic review of the literature. Journal of Management Studies, 47(6), 1154-1191.

Damanpour, F., and Schneider, M. (2006). Phases of the adoption of innovation in organizations: Effects of environment, organization and top managers. British Journal of Management, 17(3), 215-236.

Dawar, N., and Parker, P. (1994). Marketing universals: Consumers' use of brand name, price, physical appearance, and retailer reputation as signals of product quality. Journal of Marketing, 58(2), 81-95.

Dawton, D. (2011). Maximizing design investment. Design Management Review, 22(2), 2635.

Dean, D.L., Hender, J.M., Rogers, T.L., and Santanen, E.L. (2006). Identifying quality, novel, and creative ideas: Constructs and scales for idea evaluation. Journal of the Association for Information Systems, 7(10), 646-699. 
Design Council. (2004). Design index: The impact of design on stock market performance. Retrieved from: http://www.designcouncil.org.uk/

Documents/Documents/Publications/Design\%20Index\%202005_Design_Council.pdf.

Design Council. (2007). The value of design factfinder report. Retrieved from: http://www.designfactfinder.co.uk:8080/design-council/pdf/TheValueOf DesignFactfinder.pdf.

Design Council. (2008). Design returns: A review of national design strategy 2004-08. Retrieved from: http://www.designcouncil.org.uk/Documents/Documents/Publications/DesignReturns_De signCouncilAnnualReview2004_2008_Design_Council.pdf.

Di Benedetto, C.A. (2012). The JPIM thought leadership symposium. Journal of Product Innovation Management, 29(3), 344-348.

Eckman, M., and Wagner, J. (1994). Judging the attractiveness of product design: The effect of visual attributes and consumer characteristics. In C. Allen and D. Roedder-John (Eds.), Advances in Consumer Research, Vol. 21, (pp. 560-564). Provo, UT: Association for Consumer Research.

Engel, K., Diedrichs, E., and Brunswicker, S. (2008). Tangible results from IMP ${ }^{3}$ rove: Insights on innovation management in Europe. European Commission-DG Enterprise and Industry. Retrieved from: https://www.improve-innovation.eu/wpcontent/uploads/2010/07/Europe_INNOVA_paper_10_insightsoninnovation-2008.pdf.

European Commission. (2009a). Design as a driver of user-centred innovation. European Commission. Retrieved from: http://ec.europa.eu/enterprise/policies/innovation/files/ design_swd_sec501_en.pdf.

European Commission. (2009b). Results of the public consultation on design as a driver of user-centred innovation. European Commission. Retrieved from: http://ec.europa.eu/ enterprise/policies/innovation/files/results_design_consultation_en.pdf.

Filippetti, A. (2011). Innovation modes and design as a source of innovation: a firm-level analysis. European Journal of Innovation Management, 14(1), 5-26.

Fornell, C., and Larcker, D.F. (1981). Structural equation models with unobservable variables and measurement error: Algebra and statistics. Journal of Marketing Research, 18(3), $382-388$.

Fredericks, E. (2005). Cross-functional involvement in new product development: A resource dependency and human capital perspective. Qualitative Market Research: An International Journal, 8(3), 327-341.

Fulton Suri, J. (2000). Communicating with designers: The role of empathy, evidence and inspiration. Proceedings of the human factors and ergonomics society annual meeting 2000 San Diego. California. July-August.

Fulton Suri, J., and Marsh, M. (2000). Scenario building as an ergonomics method in consumer product design. Applied Ergonomics, 31(2), 151-157. 
Garber, L.L. (1995). The package appearance in choice. In F. R. Kardes and M. Sujan (Eds.), Advances in Consumer Research, Vol. 22, (pp. 653-660). Provo, UT: Association for Consumer Research.

Gattiker, T. (2012). Rethinking design. Quality Progress, 45(3), 32-37.

Gemser, G., Candi, M., and Ende, van den J. (2011). How design can improve firm performance. Design Management Review, 22(2), 72-77.

Gemser, G., Jacobs, D., and Cate, R.T. (2006). Design and competitive advantage in technology-driven sectors: The role of usability and aesthetics in Dutch IT companies. Technology Analysis and Strategic Management, 18(5), 561-580.

Gemser, G., and Leenders, M.A.A.M. (2001). How integrating industrial design in the product development process impacts on company performance. Journal of Product Innovation Management, 18(1), 28-38.

Grimaldi, M., Quinto, I., and Rippa, P. (2013). Enabling open innovation in small and medium enterprises: A dynamic capabilities approach. Knowledge and Process Management, 20(4), 199-210.

Grosskopf, A., Weske, M., Edelman, J., Steinert, M., and Leifer, L. (2010). Design thinking implemented in software engineering tools: Proposing and applying the design thinking transformation framework. Retrieved from: http://bpt.hpi.unipotsdam.de/pub/Public/AlexanderGrosskopf/DTRS8_DTinSE.pdf.

Haenlein, M., and Kaplan, A.M. (2004). A Beginner's Guide to Partial Least Squares Analysis. Understanding Statistics, 2(4), 283-297.

Han, J.K., Kim, N., and Srivastava, R.K. (1998). Market orientation and organizational performance: Is innovation a missing link? Journal of Marketing, 62(4), 30-45.

Hart, S.J., Service, L.M., and Baker, M.J. (1989). Design orientation and market success. Design Studies, 10(2), 103-111.

Hauser, J., Tellis, G.J., and Griffin, A. (2006). Research on innovation: A review and agenda for marketing science. Marketing Science, 25(6), 687-717.

Hempel, J. (2007). How venture philanthropists use design thinking to help solve real-world problems. BusinessWeek, 4025(March), 9-13.

Hernandez, N.V., Shah, J.J., and Smith, S.M. (2010). Understanding design ideation mechanisms through multilevel aligned empirical studies. Design Studies, 31(4), 382-410.

Hertenstein, J.H., Platt, M.B., and Brown, D. (2001). Valuing design: Enhancing corporate performance through design effectiveness. Design Management Journal, 12(3), 10-18.

Hertenstein, J.H., Platt, M.B., and Veryzer, R. (2005). The impact of industrial design effectiveness on corporate financial performance. Journal of Product Innovation Management, 22(1), 3-21.

Hirschman, E.C., and Solomon, M.R. (1984). Utilitarian, aesthetic, and familiarity responses to verbal versus visual advertisement. Advances in Consumer Research, 11(1), 426-431. 
Hirst, G., and Mann, L. (2004). A model of R\&D leadership and team communication: the relationship with project performance. $R \& D$ Management, 34(2), 147-160.

Hise, R.T., O’Neal, L., McNeal, J.U., and Parasuraman, A. (1989). The effect of product design activities on commercial success levels of new industrial products. Journal of Product Innovation Management, 6(1), 43-50.

Hobman, E.V., Bordia, P., and Gallois, C. (2004). Perceived dissimilarity and work group involvement: The moderating effects of group openness to diversity. Group and Organization Management, 29(5), 560-587.

Hoegg, J., Alba, J.W., and Dahl, D.W. (2010). The good, the bad, and the ugly: Influence of aesthetics on product feature judgments. Journal of Consumer Psychology, 20(4), 419430.

Hoegl, M., and Gemuenden, H.G. (2001). Teamwork quality and the success of innovative projects: A theoretical concept and empirical evidence. Organization Science, 12(4), 435449.

Hoffer, G.E., and Reilly, R J. (1984). Automobile styling as a shift variable. Applied Economics, 16(2), 291-297.

Holahan, P.J., Sullivan, Z.Z., and Markham, S.K. (2014). Product development as core competence: How formal product development practices differ for radical, more innovative, and incremental product innovations. Journal of Product Innovation Management, 31(2), 329-345.

Holloway, M. (2009). How tangible is your strategy? How design thinking can turn your strategy into reality. Journal of Business Strategy, 30(2/3), 50-56.

Hsu, S.H., Chuang, M.C., and Chang, C.C. (2000). A semantic differential study of designers' and users' product form perception. International Journal of Industrial Ergonomics, 25(4), 375-391.

Hurley, R.F., and Hult, G.T.M. (1998). Innovation, market orientation, and organizational learning: An integration and empirical examination. Journal of Marketing, 62(3), 42-54.

Hülsheger, U.R., Anderson, N., and Salgado, J.F., (2009). Team-level predictors of innovation at work: A comprehensive meta-analysis spanning three decades of research. Journal of Applied Psychology, 94(5), 1128-1145.

IBM Corp.. (2011). IBM SPSS Statistics for Windows, Version 20.0. Armonk. NY: IBM Corp..

Johansson-Sköldberg, U., Woodilla, J., and Çetinkaya, M. (2013). Design thinking: Past, present and possible futures. Creativity and Innovation Management, 22(2), 121-146.

Junginger, S. (2007). Learning to design: giving purpose to heart, hand and mind. Journal of Business Strategy, 28(4), 59-65.

Kauppinen-Räisänen, H. (2010). The impact of extrinsic and package design attributes on preferences for non-prescription drugs, Management Research Review, 33(2), 161-173. 
Kelley, T. (2001). The art of innovation: Lessons in creativity from IDEO, America's leading design firm. New York, NY: Doubleday.

Khurana, A., and Rosenthal, S.R. (1997). Integrating the fuzzy front end of new product development. Sloan Management Review, 38(2), 103-119.

Kimbell, L. (2011). Rethinking design thinking: Part I. Design and Culture, 3(3): 285-306.

Koen, P., Ajamian, G., Burkart, R., Clamen, A., Davidson, J., D’Amore, R., Elkins, C., Herald, K., Incorvia, M., Johnson, A., Karol, R., Seibert, R., Slavejkov, A., and Wagner, K. (2001). Providing clarity and a common language to the 'fuzzy front end'. Research Technology Management, 44(2), 46-55.

Koetzier, W., and Alon. A. (2013). Why "low risk" innovation is costly: Overcoming the perils of renovation and invention. Accenture. Retrieved from: http://www.accenture.com/SiteCollectionDocuments/PDF/Accenture-Why-Low-RiskInnovation-Costly.pdf.

Kohli, A.K., and Jaworski, J. (1990). Market orientation: The construct, research propositions, and managerial implications. Journal of Marketing, 54(2), 1-18.

Kotler, P., and Rath, G.A. (1984). Design: A powerful but neglected strategic tool. Journal of Business Strategy, 5(Fall), 16-21.

Kristensson, P., Gustafsson, A., and Archer, T. (2004). Harnessing the creative potential among users. Journal of Product Innovation Management, 21(1), 4-14.

Kumar, V. (2009). A process for practicing design innovation. Journal of Business Innovation, 30(2/3), 91-100.

Landwehr, J.R., McGill, A.L., and Herrman, A. (2011). It's got the look: The effect of friendly and aggressive 'facial' expressions on product liking and sales. Journal of Marketing, 75(3), 132-146.

Leonard, D., and Rayport, J.B. (1997). Sparking innovation through empathic design. Harvard Business Review, 75(6), 102-113.

Liedtka, J. (2011). Learning to use design thinking tools for successful innovation. Strategy and Leadership, 39(5), 13-19.

Lindell, M.K., and Whitney, D.J. (2001). Accounting for common method variance in crosssectional research designs. Journal of Applied Psychology, 86(1), 114-121.

Lindström, M., and Pajarinen, M. (2006). The use of design in Finnish manufacturing firms. Retrieved from: http://mikael.etla.fi/files/1523_Dp1017.pdf.

Litchfield, R.C. (2008). Brainstorming reconsidered: A goal-based view. Academy of Management Review, 33(3), 649-88.

Lockwood, T. (2010). Transition: Becoming a design-minded organization. In Thomas Lockwood (Eds.), Design thinking: Integrating innovation, customer experience and brand value (pp. 81-95). New York, NY: Allworth.

Lockwood, T. (2011). It's no longer a question of to measure or not to measure. Design Management Review, 22(2), 5. 
Magnusson, P.R. (2009). Exploring the contributions of involving ordinary users in ideation of technology-based services. Journal of Product Innovation Management, 26(5), 578593.

Mahr, D., Kalogeras, N., and Odekerken-Schröder, G. (2013). A service science approach for improving healthy food experiences. Journal of Service Management, 24(4), 435-471.

Mahr, D., and Lievens, A. (2012). Virtual lead user communities: Drivers of knowledge creation for innovation. Research Policy, 41(1), 167-177.

Mahr, D., Lievens, A., and Blazevic, V. (2014). The value of customer co-created knowledge during the innovation process. Journal of Product Innovation Management, 31(3), 599615.

Marketing Science Institute (2014). 2014-2016 Research Priorities. Retrieved from: http://www.msi.org/research/2014-2016-research-priorities/.

Martin, N. (2008). Habit: The 95\% behavior marketers ignore. Upper Saddle River, NJ: Pearson Education.

Martin, R. (2009). The design of business: Why design thinking is the next competitive advantage. Boston, MA: Harvard Business Press.

Martin, R. (2011). The innovation catalyst. Harvard Business Review, 89(6), 82-87.

Moll, I., Montana, J., Guzmán, F., and Parellada, F.S. (2007). Market orientation and design orientation: A management model. Journal of Marketing Management, 23(9-10), 861876.

Mortara, L., Napp, J.J., Slacik, I., and Minshall, T. (2009). How to implement open innovation: Lessons from studying large multinational companies. Retrieved from: http://www-cikc.eng.cam.ac.uk/wp-content/docs/COIN.pdf.

Moss, G., Gunn, R., and Heller, J. (2006). Some men like it black, some women like it pink: Consumer implications of differences in male and female website design. Journal of Consumer Behaviour, 5(4), 328-341.

Moultrie, J., and Livesey, F. (2014). Measuring design investment in firms: Conceptual foundations and exploratory UK survey. Research Policy, 43(3), 570-587.

Mrazek, D., Lucente, S., Wakid, K., Sato, S., Wai, C., Menter, A., and Hartley, P. (2011). The holy grail of design measurement. Design Management Review, 22(2), 6-16.

Nagji, B., and Locsin, M. (2009). Innovation by design. Pharmaceutical Executive, 29(10), $68-70$.

Narver, J.C., Slater, S.F., and MacLachlan, D.L. (2004). Responsive and proactive market orientation and new-product success. Journal of Product Innovation Management, 21(5), 334-347.

National Agency for Enterprise and Housing. (2003). The economic effects of design. Retrieved from: http://www.ebst.dk/file/1924/the_economic_effects_of_designn.pdf. 
Nefiodow, L.A. (2006). Der sechste Kondratieff: Wege zur Produktivität und Vollbeschäftigung im Zeitalter der Information. Sankt Augustin, Germany: Rhein-SiegVerl.

Neumeier, M. (2008). The designful company. Design Management Review, 19(2), 10-15.

Noble, C.H. (1999). The eclectic roots of strategy implementation research. Journal of Business Research, 45(2), 119-134.

Noble, C.H., and Kumar, M. (2010). Exploring the appeal of product design: A grounded, value-based model of key design elements and relationships. Journal of Product Innovation Management, 27(5), 640-657.

Oakley, M. (1990). Design management. Cambridge/Oxford, UK: Blackwell.

Orth, U.R., and Malkewitz, K. (2008). Holistic package design and consumer brand impressions. Journal of Marketing, 72(3), 64-81.

Osborn, A.F. (1957). Applied imagination: Principles and procedures of creative problem solving. New York, NY: Charles Scribner's Sons.

Ostrom, A.L., Bitner, M.J., Brown, S.W., Burkhard, K.A., Goul, M., Smith-Daniels, V., Demirkan, H., and Rabinovich, E. (2010). Moving forward and making a difference: Research priorities for the science of service. Journal of Service Research, 13(1): 4-36.

Page, C., and Herr, P.M. (2002). An investigation of the processes by which product design and brand strength interact to determine initial affect and quality judgments. Journal of Consumer Psychology, 12(2), 133-147.

Pantin-Sohier, G. (2009). The influence of the product package on functional and symbolic associations of brand image. Recherche et Applications en Marketing, 24(2), 53-71.

Pelham, A.M., and Wilson, D.T. (1996). A longitudinal study of the impact of market structure, firm structure, strategy, and market orientation culture on dimensions of smallfirm performance. Journal of the Academy of Marketing Science, 24(1), 27-43.

Perks, H., Cooper, R., and Jones, C. (2005). Characterizing the role of design in new product development: An empirically derived taxonomy. Journal of Product Innovation Management, 22(2), 111-127.

Plattner, H., Meinel, C., and Weinberg, U. (2009). Design thinking: Innovation lernenIdeenwelten öffnen. Munich: mi-Wirtschaftsbuch.

Podsakoff, P.M., MacKenzie, S.B., Lee, J.-Y., and Podsakoff, N.P. (2003). Common method biases in behavioral research: A critical review of the literature and recommended remedies. Journal of Applied Psychology, 88(5), 879-903.

Potter, S., Roy, R., Capon, C.H., Bruce, M., Walsh, V., and Lewis, J. (1991). The benefits and costs of investment in design: Using professional design expertise in product, engineering and graphics projects. Retrieved from: http://design.open.ac.uk/research/documents/CID Reportv2_000.pdf.

Quester, P.G., and Smart, J. (1998). The influence of consumption situation and product involvement over consumers' use of product attribute. Journal of Consumer Marketing, 15(3), 220-238. 
Raghubir, P., and Greenleaf, E.A. (2006). Ratios in proportion: What should the shape of the package be? Journal of Marketing, 70(April), 95-107.

Ramlau, U.H., and Melander, C. (2004). In Denmark, design tops the agenda. Design Management Review, 15(4), 48-54.

Rampino, L. (2011). The innovation pyramid: A categorization of the innovation phenomenon in the product-design field. International Journal of Design, 5(1), 3-16.

Ravasi, D., and Stigliani, I. (2012). Product design: A review and research agenda for management studies. International Journal of Management Reviews, 14(4), 464-488.

Reid, S.E., and Brentani, de U. (2004). The fuzzy front end of new product development for discontinuous innovations: A theoretical model. Journal of Product Innovation Management, 21(3), 170-184.

Reinartz, W.J., Haenlein, M., and Henseler, J. (2009). An empirical comparison of the efficacy of covariance-based and variance-based SEM. International Journal of Research in Marketing, 26(4), 332-344.

Rindova, V.P., and Petkova, A.P. (2007). When is a new thing a good thing? Technological change, product form design, and perceptions of value for product innovations. Organization Science, 18(2), 217-232.

Ringle, C.M., Wende, S., and Will, A. (2005). SmartPLS 2.0 (beta), www.smartpls.de, Hamburg.

Rousseau, V., Aube, C., Chiocchio, F., and Morin, E. (2008). Social interactions at work and psychological health: The role of leader-member exchange and work group integration. Journal of Applied Social Psychology, 38(7), 1755-1777.

Roy, R. (1994). Can the benefits of good design be quantified? Design Management Journal, $5(2), 9-17$.

Roy, R., and Potter, S. (1990). Managing design projects in small and medium-sized firms. Technology Analysis and Strategic Management, 2(3), 321-336.

Roy, R., and Riedel, J.C.K.H. (1997). Design and innovation in successful product competition. Technovation, 17(10), 537-548.

Ruyter, de J.C., and Wetzels, M.G.M. (1996). Two sides of the same story: Measuring different quality perceptions of the dyadic service encounter with the SERVCON instrument, Total Quality Management. Total Quality Management, 7(6), 595-604.

Sato, S. (2009). Beyond good: great innovations through design. Journal of Business Strategy. $30(2 / 3), 40-49$.

Schirr, G.R. (2012). Flawed tools: The efficacy of group research methods to generate customer ideas. Journal of Product Innovation Management, 29(3), 473-488.

Schmid, J., and Leiman, J.M. (1957). The development of hierarchical factor solutions. Psychometrika, 22(1), 53-61. 
Seidel, V.P., and Fixson, S.K. (2013). Adopting "design thinking" in novice multidisciplinary teams: The application and limits of design methods and reflexive practices. Journal of Product Innovation Management, 30(issue supplement S1), 19-33.

Simons, T., Gupta, A., and Buchanan, M. (2011). Innovation in R\&D: Using design thinking to develop new models of inventiveness, productivity and collaboration. Journal of Commercial Biotechnology, 17(4), 301-307.

Sivasubramaniam, N., Liebowitz, S.J., and Lackman, C.L. (2012). Determinants of new product development team performance: A meta-analytic review. Journal of Product Innovation Management, 29(5), 803-820.

Solum, N.H., Smith, K., and Karlsen, E.N. (1996). Design and innovation in Norwegian industry. Retrieved from: http://survey.nifu.no/step/reports/Y1996/1296.pdf.

Sutton, R.I., and Hargadon, A. (1996). Brainstorming groups in context: Effectiveness in a product design firm. Administrative Science Quarterly, 41(4), 685-718.

Swan, K.S., Kotabe, M., and Allred, B.B. (2005). Exploring robust design capabilities: Their role in creating global products, and their relationship to firm performance. Journal of Product Innovation Management, 22(2), 144-164.

Talke, K., Salomo, S., Wierenga, J.E., and Lutz, A. (2009). What about design newness? Investigating the relevance of a neglected dimension of product innovativeness. Journal of Product Innovation Management, 26(6), 601-615.

Tenenhaus, M., Vinzi, V.E., Chatelin, Y.M., and Lauro, C. (2005). PLS path modeling. Computational Statistics \& Data Analysis, 48(1), 159-205.

Tischler, L. (2009). A designer takes on his biggest challenge ever. Fast Company, 132(February), 78-83.

Townsend, C. and Sood, S. (2009). The impact of product design on choice: A dual-process explanation, UCLA Anderson School of Management. Retrieved from:

http://management.ucsd.edu/faculty/seminars/2009/papers/townsend.pdf.

Tranfield, D., Denyer, D., and Smart, P. (2003). Towards a methodology for developing evidence-informed management knowledge by means of systematic review. British Journal of Management, 14(3), 207-222.

Ungaretti, T., Chomowicz, P., Canniffe, B.J., Johnson, B., Weiss, E., Dunn, K., and Cropper, C. (2009). Business + design: Exploring a competitive edge for business thinking. S.A.M. Advanced Management Journal, 74(3), 4-11, 43.

Venkatesh, A., Digerfeldt-Mansson, T., Brunel, F.F., and Chen, S. (2012). Design orientation: A grounded theory analysis of design thinking and action. Marketing Theory, 12(3), 289309.

Verganti, R. (2006). Innovating through design. Harvard Business Review, 84(12), 114-122.

Verganti, R. (2009). Design-driven innovation: Changing the rules of competition by radically innovating what things mean. Boston, MA: Harvard Business Press. 
Veryzer, R.W. (1993). Aesthetic response and the influence of design principles on product preferences. In L. Mc Allister and M. Rothschild (Eds.), Advances in Consumer Research, Vol. 20, (pp. 224-231). Provo, UT: Association for Consumer Research.

Veryzer, R.W. (1995). The place of product design and aesthetics in consumer research. In F.R. Kardes and M. Sujan (Eds.), Advances in Consumer Research, Vol. 22, (pp. 641645). Provo, UT: Association for Consumer Research.

Veryzer, R.W., and Borja de Mozota, B. (2005). The impact of user-oriented design on new product development: An examination of fundamental relationships. Journal of Product Innovation Management, 22(2), 128-143.

Veryzer, R.W., and Hutchinson, J.W. (1998). The influence of unity and prototypicality on aesthetic responses to new product designs. Journal of Consumer Research, 24(March), 374-394.

Walker, O.C., and Ruekert, R.W. (1987). Marketing's role in the implementation of business strategies: A critical review and conceptual framework. Journal of Marketing, 51(July), $15-33$.

Walton, T. (2011). Those elusive stats. Design Management Review, 22(2), 3.

Ward, A., Runcie, E., and Morris, L. (2009). Embedding innovation: design thinking for small enterprises. Journal of Business Strategy, 30(2/3), 78-84.

Wattanasupachoke, T. (2012). Design thinking, innovation and performance: An empirical examination, International Journal of Management and Innovation, 4(1), 1-14.

Wetzels, M.G.M., Odekerken-Schröder, G., and Oppen, van C. (2009). Using PLS path modeling for assessing hierarchical construct models: Guidelines and empirical illustration. MIS Quarterly, 33(1), 177-195.

Whicher, A., Raulik-Murphy, G., and Cawood, G. (2011). Evaluating design: Understanding the return on investment. Design Management Review, 22(2), 44-52.

Woodward, D. (2010). Winning by design. Director, 63(5), 50-53.

Yamamoto, M., and Lambert, D.R. (1994). The impact of product aesthetics on the evaluation of industrial products. Journal of Production and Innovation Management, 11(4), 309324.

Yang, S., and Raghubir, P. (2005). Can bottles speak volumes? The effect of package shape on how much to buy. Journal of Retailing, 81(4), 269-281.

Zajonc, R.B., and Markus, H. (1982). Affective and cognitive factors in preferences. Journal of Consumer Research, 9(2), 123-131.

Zec., P. (2011). Design value. Design Management Review, 22(2), 36-42.

Zhou, K. Z., Gao, G. Y., Yang, Z., and Zhou, N. (2005). Developing strategic orientation in China: Antecedents and consequences of market and innovation orientations. Journal of Business Research, 58(8), 1049-1058. 


\section{SUMMARY}

Companies have increasingly become interested in deciphering the DNA of design-oriented companies and applying design processes, principles and tools to various innovation contexts. Yet, the outcome-based discourse on design is highly fragmented and investigations across research streams have been widely neglected, although authors have already indicated that "a glance beyond the borders" may have the greatest potential in order to gain new insights on the topic. The present dissertation addresses this gap by taking a more holistic perspective throughout three different studies, thereby contributing to the established design management and the emerging design thinking literature as well as to innovation management in general.

In the first study, we systematically review outcome-based design studies across distinct literature streams. In doing so, we synthesize different design perspectives, responses and returns highlighted within the discourses. This results in a holistic framework that demonstrates how design impacts people, organizations and stock markets, the contexts in which these influences have been assessed and how the impact of design has been measured. These findings provide valuable insights for researchers and managers interested in assessing the impact of design. Moreover, the meta perspective opens new avenues for further research within and across research streams. The review uncovers, for instance, which design outcomes were under-researched within a certain research stream and might be addressed by future investigations. Furthermore, the synthesis suggests enriching the explanation of design success originating from the established, empirically-based design management literature with conceptual considerations of the emerging design thinking literature.

The second study conceptualizes design orientation as the degree to which a company adopts design thinking principles and applies design processes and tools throughout the innovation process. In turn, the antecedents and consequences of design orientation are examined. Our 
empirical findings emphasize the importance of a positive top management attitude toward innovation, a profound implementation of an innovation strategy, an organizational involvement during the innovation process, and a formalized innovation process in order to enable design to transcend organizations. In turn, design-oriented companies benefit from an enhanced innovation effectiveness and efficiency as well as increased financial innovation returns. With respect to contingency effects, the results suggest that external collaboration deflects from a design orientation and that the impact of design orientation on innovation performance is stronger for companies that predominantly focus on radical rather than incremental as well as product rather than non-product innovation projects.

Finally, the third study explores the usefulness of the design thinking process in a fuzzy front end context. Based on a laboratory experiment with non-design students, we demonstrate that an application of observation, brainstorming and prototyping steps enhances teamwork and innovation output quality respectively. In particular, the empirical results show that the exploitation of external sources and the internal communication among group members improves, if novice teams apply the design thinking process. Moreover, the results show that internal communication drives group cohesion and this in turn leads to a better understanding of shared solutions among team members. Focusing on teams' innovation outputs, we demonstrate that design thinking enhances its quality in terms of innovation outputs' novelty, relevance and specificity. 


\section{VALORIZATION OPPORTUNITIES - A EUROPEAN PERSPECTIVE}

The World Economic Forum's Global Competitiveness Report 2014-2015 recently demonstrated that the economies of most European countries have reached the innovationdriven stage, in which high wages and the associated high standard of living can only be sustained if businesses are able to launch new and unique offers ${ }^{1}$. European company leaders across industries seem to have recognized this need, as a recent survey conducted by the management consultancy Bain \& Company shows. In particular, the results highlight that innovation ranks among managers' fastest growing strategic priorities ${ }^{2}$.

The present dissertation offers valorization opportunities that address the European economic and managerial need for innovation in two ways. On the one hand, the studies carried out provide new insights on how to foster innovation within established organizations on a corporate as well as on a project level. The implications of the findings for academia, managers and policy makers are discussed at the end of each chapter. Moreover, we provide a more holistic perspective on these implications within the conclusion chapter. Those new insights can be further spread across society via media such as weblogs or consumer publications, which address a broader, non-scientific audience. On the other hand, the present dissertation provides a blueprint for a design-driven innovation management consultancy, which could support companies in becoming more innovative by design applications and which would be based on service innovations in its own right. In this addendum, we would like to elaborate on this latter valorization opportunity by demonstrating how the key findings of each study could be transformed into distinctive new management consulting offers.

\footnotetext{
${ }^{1}$ Retrieved from: http://www3.weforum.org/docs/WEF_GlobalCompetitivenessReport_2014-15.pdf

${ }^{2}$ Retrieved from: http://www.bain.com/Images/BAIN_BRIEF_Management_Tools_\%26_Trends_2013.pdf 
To begin with, the design-driven innovation management consultancy could target managers via white papers, case studies or reports in which a new, holistic perspective on design success is communicated and the company's unique competencies are highlighted. In particular, the new founded consultancy could describe the Design Success Chain, developed in the first study of the present dissertation, in order to demonstrate in which manifold ways companies across industries can benefit from cooperating with designers and implementing design processes, principles and tools. Having attracted potential clients, consulting offers could be highlighted within the publications. From a design outcome perspective, the Design Success Chain could be described as a management tool that assesses a company's design impact in its entirety. Not only could such a tool quantify people's design-led responses, but it could also track the impact of design on the organization and even the stock market. Consulting projects based on this tool could be used to support clients in selecting the right metrics (e.g. American Customer Satisfaction Index, sales, price-to-earnings ratio), taking the measurements (e.g. based on market data, surveys or client's internal sources) and assessing the relationships among the design success steps. In the long run, clients could be supported in implementing the Design Success Chain as a controlling instrument that regularly monitors the success of design efforts along the design success stages. If a client seeks to assess its relative design strengths compared to its competitors, the Design Success Chain could also be used as a framework to benchmark the client's design performance within a certain industry. Moreover, the conceptual model could be used to develop different scenarios, highlighting the potential impact of new design applications on stakeholders, clients' businesses and shareholders. Based on the quantitative results of all these attempts, recommendations on where and how to improve the impact of design could be developed and should complement the consulting offer. 
Shifting the perspective from design outcomes towards clients' corporations, the designdriven innovation management consultancy could offer business transformation projects, in which clients are supported in becoming more design-oriented for the sake of enhancing innovativeness. In particular, the firm factors identified in the second study could serve as a framework for the project's execution. Following a top-down approach, the consultants should first address clients' top management board and change or strengthen its attitude toward innovation. The innovation performance results of this study can serve as a first trigger to spark managements' interest in innovation. Second, the consultants should guide the company in implementing an innovation strategy. The items of the innovation strategy-related construct used in this study provide valuable hints on how to operationalize this. Third, the consultants should help to diminish the boundaries between departments. While interdisciplinary workshops may be a good starting point to improve client employees' understanding for the other disciplines, in the long run the consultancy should implement regular interdisciplinary meetings, in which new ideas are discussed from various perspectives. Finally, the design-driven innovation management consultancy should help its clients to implement a formal innovation process. In particular, the consultants should support their clients in defining roles, authorities and procedures, in order to ensure that design processes, principles and tools guide each step of the innovation process. If the client follows an open innovation strategy, the consultants should furthermore support the company in balancing both management approaches. One way to do that could be to demonstrate how design processes, principles and tools can be used together with external actors.

On a team level, the consulting portfolio could encompass design thinking workshops that improve client employees' teamwork during the fuzzy front end of the innovation process and their output quality respectively. Based on the results of the third study, a three step approach can be offered, in which the consultancy guides the clients' employees in adopting the design 
thinking process. First, client teams are confronted with a presentation held by a consultant about the basic elements of the design thinking process, namely observation, brainstorming and idea prototyping and testing. In doing so, clients' employees shall learn how to "observe" using tools such as videos \& pictures, how to conduct brainstorming sessions based on rules \& templates and how to build prototypes using instruments such as sketches, flow charts \& storyboards. Second, the consultants guide small teams of approximately five persons each through an abstract ideation task. During this task, team members shall learn to apply the design thinking process. Therefore, the task as well as the design thinking tools shall be selected by the consultancy with respect to how easily they are applicable by clients' teams. Finally, the consultants support the teams in adopting the design thinking process to one of the clients' real issues. Further consulting opportunities arise in supporting the clients in identifying the relevant areas for improvement.

Taken together, the design-driven innovation management consultancy could offer a new portfolio of consulting services that would help clients to track design efforts holistically and support them in implementing design processes, principles and tools on a corporate as well as on a project level. In doing so, clients are likely to benefit from a more precise basis for any design-related decision, enhanced innovation teamwork and an improved innovation performance. Given this, the consultancy outlined offers a clear differentiating factor over the extant design (thinking) consultancies, because it attempts to sustainably improve clients' design and innovation capabilities, while the extant design consultancies predominantly aim to solve clients' one-off design and innovation tasks themselves. Besides this, the established management consultancies have not yet tapped into design-driven innovation, which would differentiate the consultancy outlined in this market as well. Considering the fact that the innovation management consulting market in Europe is worth approximately $€ 6$ bn and is one 
of the fastest growing of its kind, ${ }^{3}$ the potential competitive advantage of the design-driven innovation management approach points at a promising business opportunity.

${ }^{3}$ Estimated based on "Survey of the European Management Consultancy 2011/2012" published by faeco and "Facts \& Figures zum Beratermarkt 2012/2013" published by BDU 